Rodolfo Jasão Soares Dias

Morfologia e sedimentação na Plataforma Continental Externa e Talude ao largo da Ilha de São Sebastião - SP

\begin{abstract}
Dissertação apresentada ao
Instituto Oceanográfico da

Universidade de São Paulo, como parte dos requisitos para obtenção do título de Mestre em Ciências, Programa de Oceanografia, área de Oceanografia Geológica.
\end{abstract}

Orientador:

Prof. Dr. Michel Michaelovicth de Mahiques

São Paulo 
Universidade de São Paulo

Instituto Oceanográfico

\title{
Morfologia e sedimentação na Plataforma Continental Externa e Talude ao largo da Ilha de São Sebastião - SP
}

\author{
Rodolfo Jasão Soares Dias
}

Dissertação apresentada ao Instituto Oceanográfico da Universidade de São Paulo, como parte dos requisitos para obtenção do título de Mestre em Ciências, área de Oceanografia Geológica.

\section{VERSÃO CORRIGIDA}

Julgada em

$\operatorname{Prof}(a) \cdot \operatorname{Dr}(\mathrm{a})$.

Conceito

$\operatorname{Prof}(\mathrm{a}) . \operatorname{Dr}(\mathrm{a})$.

Conceito

Prof(a). $\operatorname{Dr}(a)$.

Conceito 


\section{AGRADECIMENTOS}

Primeiramente dedico este trabalho à minha família, agradecendo-os pela compreensão e apoio dado nesta jornada. Também peço desculpas pela minha ausência em muitos momentos.

Ao amigo e orientador, Michel Mahiques. Muito obrigado pelo total apoio e ajuda neste e em muitos outros trabalhos.

Ao amigo Clodoaldo pela ajuda durante esses anos todos.

Ao amigo Paco pela ajuda dada; a Isabel pela ajuda na criaçãp do bloco 3D; a Daniela pelas revisões; ao Hélio pela colaboração.

Meus agradecimentos para os integrantes do Projeto Nap-Geosedex e também aos do curso PASI. Agradeço também toda tripulação do Alpha Crucis pelo apoio e ajuda nos cruzeiros.

Aos amigos do IO pela ajuda direta e indireta para realização deste trabalho. 
RESUMO

ABSTRACT

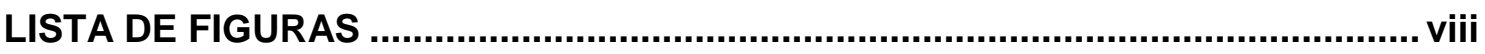



ÍNDICE DE ABREVIATURAS .............................................................................ii

1. INTRODUÇÃO

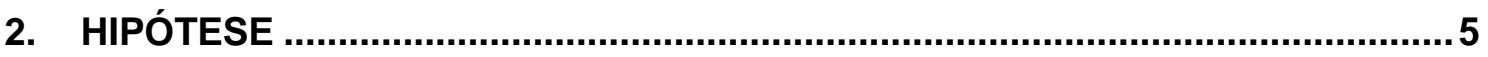

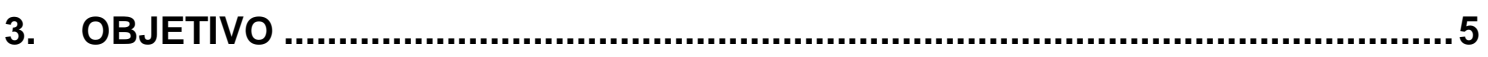

4. ÁREA DE ESTUDO

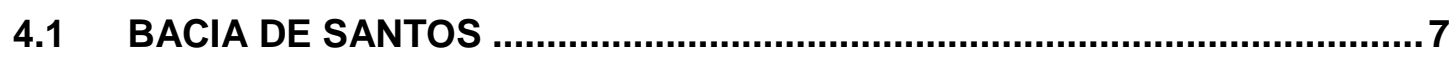

4.2 EVOLUÇÃO TECTONICA

4.3 GEOMORFOLOGIA E DISTRIBUIÇÃO SEDIMENTAR ..............................11

4.3.1 PLATAFORMA CONTINENTAL …....................................................

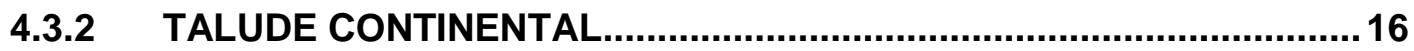

4.4 MASSAS DE ÁGUAS E CIRCULAÇÃO ………......................................19

4.4.1 ESTRUTURA VERTICAL DE MASSAS DE ÁGUA..............................19

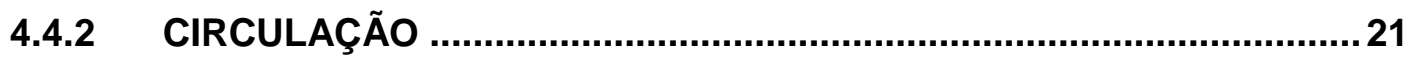

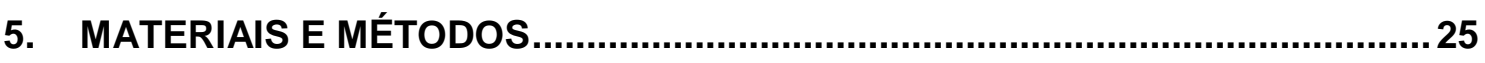

5.1 VELOCIDADE DE SOM NA ÁGUA

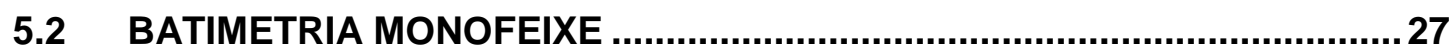


5.3 PERFILAGEM SísmiCA DE ALTA RESOLUÇÃo.

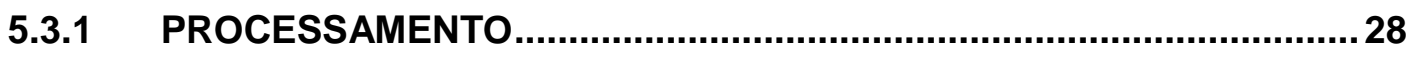

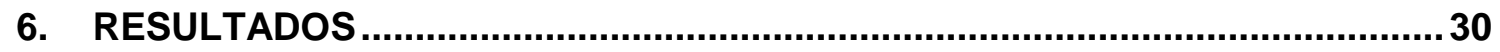

6.1 PLATAFORMA CONTINENTAL EXTERNA …..........................................

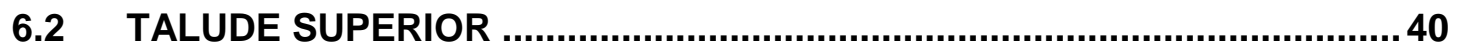

6.3 TALUDE INFERIOR ................................................................................

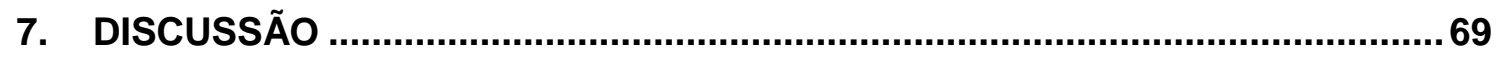

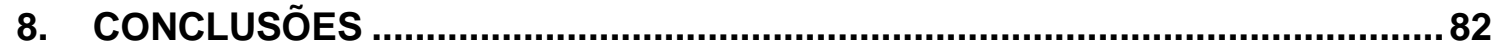

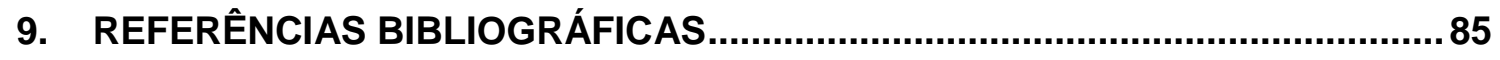




\section{RESUMO}

A análise batimétrica e sísmica de alta resolução realizadas na Plataforma Continental Externa e Talude ao largo da llha de São Sebastião permitiu elaborar um modelo morfológico e sedimentar para região. A Plataforma Continental Externa apresenta uma morfologia extremamente irregular, com presenças de montiformas, escarpas e depressões erosivas. Estas feições e os seus sedimentos superficiais são de origem carbonáticas. $\mathrm{Na}$ região da quebra da Plataforma e Talude superior ocorre um intenso processo erosivo, causado pela ação da Corrente do Brasil ao longo do tempo, formando canais e escarpas na região. Ao longo do Talude observam-se inúmeras feições que estão distribuídas por faixas de profundidade. Nos setores mais rasos há presença de ondas de sedimento e pockmarks ativos e inativos. Abaixo dos 1000 metros as feições predominantes são os canais e depósitos contorníticos, como o Canal de Santos, que possui expressão regional, localizado paralelamente ao talude. Esses depósitos e canais contorníticos são formados e retrabalhados pela incidência das Correntes de Contorno Intermediária $(\mathrm{CCl})$ e da Corrente Contorno Profunda, que sofreram variações ao longo do tempo.

Palavra chave: sedimentação; margem continental; geomorfologia submarina. 


\section{ABSTRACT}

The analysis of high-resolution bathymetric and seismic data from the Outer Continental Shelf and Slope in front of São Sebastião's Island allowed us to elaborate a morphological and sedimentary model for the region. The Outer Continental Shelf has an extremely irregular morphology, with the presence of montiforms, scarp and erosive depressions. These features and surface sediments are carbonate. In the shelf break and upper slope occurs an intense erosion, caused by the action of the Brazil Current through time, forming channels and scarps in the area. It was observed that the features over the slope are distributed by depth ranges. In shallower sectors was found active and inactive feature such as sediment waves and pockmarks. Below 1000 meters the predominant features are channels and contourite deposits such as Santos's Channel, which has a regional expression and is located parallel to the slope. The formation and rework of these features occurs by the incidence of intermediate boundary current (IBC) and deep boundary current (DBC) and their variation through time.

Keywords: sedimentation; continental margin; submarine geomorphology. 


\section{LISTA DE FIGURAS}

Figura 1. Mapa ilustrando a Bacia de Santos e em retângulo preto a área de estudo.

(modificado Reis et al. (2013)).

Figura 2. Tabela geológica modificada de Moreira et al. (2007)

10

Figura 3. Compilação das curvas da variação do nível médio do mar baseado na razão isotópica $\delta^{18} \mathrm{O}$ para plataformas continentais (Reis et al. 2013).

Figura 4. Mapa granulométrico da distribuição de sedimentos na Bacia de Santos (modificado Figueiredo Jr e Tessler, 2004).

Figura 5. Mapa da composição sedimentar na Bacia de Santos (modificado Figueiredo Jr e Tessler, 2004).

Figura 6. Mapa demonstrando a localização de alguns perfis batimétricos da Bacia de Santos obtidos pelo programa Revizee (modificado Figueiredo Jr e Tessler, 2004).

Figura 7. Perfis batimétricos na porção nordeste da Bacia de Santos (Figueiredo Jr e Tessler, 2004).

Figura 8. Esquema do padrão de circulação da Corrente do Brasil (BC - vermelho) e da Corrente de Contorno Intermediária (IWBC - Azul) (Biló et al. 2014)

Figura 9. Mapa da localização das linhas que foram realizadas batimetria e perfilagem sísmica.

Figura 10. Mapa com a localização dos pontos da perfilagem com XBT. 26

Figura 11. Mapa com as linhas sondadas e a nomenclatura adotada. 30

Figura 12. Perfil batimétrico da Plataforma Externa e Talude Superior da Seção 1. 33

Figura 13. Perfil batimétrico da Plataforma Externa da Seção 2. 33

Figura 14. Perfil batimétrico da Plataforma Externa e da quebra da Plataforma da Seção 3.... 34

Figura 15. Perfil batimétrico da Plataforma Externa e da quebra da Plataforma da Seção 4 .... 34

Figura 16. Perfil batimétrico da Plataforma Externa e inicio do Talude Superior da Seção 8.... 35

Figura 17. Perfil batimétrico da Plataforma Externa e Talude Superior da Seção 10. .35 
Figura 18. Perfil sísmico da Seção 1, destacando a quebra da plataforma e início do Talude superior.

Figura 19. Perfil sísmico da Seção 2 do setor interno da Plataforma Externa.

Figura 20. Perfil sísmico da Seção 2 da Plataforma Externa, dando destaque a escarpas e discordância erosiva.

Figura 21. Perfil sísmico da Plataforma da Seção 3. Destaque para refletores progradacionais e montiformas na superfície.

Figura 22. Perfil sísmico da Plataforma da Seção 5. Destaque para paleocanais preenchidos sendo recoberta pela montiformas.

Figura 23. Perfil batimétrico do Talude Superior da Seção 4.

Figura 24. Perfil batimétrico do Talude Superior da Seção 9.

Figura 25. Perfil sísmico da Seção 2 destacando a presença do canal de erosivo e mudança no padrão de reflexão.

Figura 26. Perfil sísmico da seção 3, com destaque a quebra da Plataforma, o canal erosivo e a mudança no padrão de reflexão do pacote sedimentar. 44

Figura 27. Perfil sísmico do Talude Superior da Seção 1, demonstrando os dois canais, paleocanal e ondas de sedimento.

Figura 28. Perfil sísmico do Talude Superior da Seção 4, demonstrando os canais, paleocanais e superfície erosiva. 45

Figura 29. Perfil sísmico da Seção 6 destaque para o canal, escarpa e superfície erosiva. ..... 46

Figura 30. Perfil sísmico da Seção 7 destacando a zona de deformação, paleocanal e superfície erosiva.

Figura 31. Perfil sísmico do Talude Superior da Seção 2 destacando ondas de sedimento na base do registro.

Figura 32. Perfil sísmico do Talude Superior da Seção 5 destacando as ondas de sedimento. 47

Figura 33. Perfil batimétrico da Seção 1, com destaque para as feições do Talude inferior. ....50

Figura 34. Perfil batimétrico da Seção 4, com destaque para as feições do Talude inferior. .... 50

Figura 35. Perfil batimétrico da Seção 8, com destaque para as feições do Talude inferior. .... 51 
Figura 36. Perfil batimétrico da Seção 9, com destaque para as feições do Talude inferior. ....51

Figura 37. Perfil batimétrico da Seção T3 destacando os dois canais. .52

Figura 38. Perfil batimétrico da Seção T4 destacando as feições contorníticas e elevações.... 52

Figura 39. Perfil batimétrico da Seção T5 destacando três canais principais. 53

Figura 40. Perfil batimétrico da Seção T6 destacando três canais principais. 53

Figura 42. Padrão de reflexão no Talude, seção 4. 54

Figura 41. Padrão de reflexão no Talude, seção 1. 54

Figura 43. Perfil sísmico do Talude inferior da Seção 6, destacando pockmarks com exsudação de gás e outro inativo e soterrado. 55

Figura 44. Perfil sísmico do Talude inferior da Seção 3, destacado o pockmark com exsudação de gás. 56

Figura 45. Perfil sísmico do Talude inferior da Seção 3 destacando o pockmark com exsudação de gás. .56

Figura 46. Perfil sísmico do Talude inferior da seção 5 destacando dois canais contornítico 1250 e $1330 \mathrm{~m}$

Figura 47. Perfil sísmico do Talude inferior destacando contornito na isóbata de $1270 \mathrm{~m}$. .57

Figura 48. Perfil sísmico T3 paralelo ao Talude inferior, destacando os dois canais. 60

Figura 49. Perfil sísmico T4 transversal ao Talude, destacando feições contorníticas e elevações com deformação dos refletores.

Figura 50. Perfil sísmico do Talude inferior da Seção 1, com destaque para o Canal de Santos e depósitos contorníticos.

Figura 51. Perfil sísmico do Taludo inferior da Seção 4, com destaque a inúmeras feições contorníticas e ao Canal de Santos.

Figura 52. Perfil sísmico do Taludo inferior da Seção 8, com destaque ao Canal de Santos, canais e depósitos contorníticos.

Figura 53. Perfil sísmico do Taludo inferior da Seção 9, com destaque ao Canal de Santos, canais e depósitos contorníticos. 
Figura 54. Perfil sísmico do Taludo inferior da Seção 10, com destaque ao Canal de Santos, canais e depósitos contorníticos.

Figura 55. Perfil sísmico do Taludo inferior da Seção 11, com destaque ao Canal de Santos e depósito contornítico.

Figura 56. Perfil sísmico T5 transversal ao Taludo inferior, com destaque aos inúmeros canais formados na área.

Figura 57. Perfil sísmico T6 transversal ao Talude inferior destacando canais perpendiculares ao talude.

Figura 58. Perfil sísmico T7 transversal ao Talude inferior, destaque para deposito contornítico e refletores erodidos na setor superior.

Figura 59. Canal localizado sobre o talude superior. Verifica-se a presença de três paleocanais.

Figura 60. Modelo esquemático da localização do núcleo da CB. (A) períodos transgressivos e

(B) regressivos (extraído de Mahiques et al., 2007)

Figura 61. Seção sísmica com presença de ondas de sedimento na sua base. As marcações refletem as unidades deposicionais ao longo da coluna.

Figura 62. Seção transversal da velocidade na Bacia de Santos. Velocidades negativas são orientadas para sudoeste (Biló et al. 2014).

Figura 63. Seção sísmica do Canal de Santos, onde visualiza-se a mudança no padrão de deposição plano-paralelo para ondulado, junto a calha do canal.

Figura 64. Bloco sísmico 3D da região do Canal de Santos. Setas azuis demonstrando o fluxo durante sequencia U5 e setas em vermelho, fluxos perpendiculares ao talude formando canais tributários (Duarte e Viana, 2007).

Figura 65. Deformação dos refletores nas seções sísmicas T3 e T4. 80

Figura 66. Bloco esquemático do modelo morfológico e sedimentar da área de estudo. .81 


\section{LISTA DE TABELAS}

Tabela 1. Limites termohalinos e espessuras das massas de água na região .20

Tabela 2. Descrição das seções batimétricas na Plataforma Continental Externa. .32 


\section{ÍNDICE DE ABREVIATURAS}

$\mathrm{CB}=$ Corrente do Brasil

$\mathrm{CCP}=$ Corrente de Contorno de Profunda

$\mathrm{CCl}=$ Corrente de Contorno Intermediária

$\mathrm{Km}=$ Quilômetros

$M=$ Metros

${ }^{\circ} \mathrm{C}=$ Graus Celsius

Ma $=$ Milhões de anos

Sx = Seção $X$

PCE $=$ Plataforma Continental Externa

AT = Água Tropical

ACAS = Água Central do Atlântico Sul

AIA = Água Intermediária Antártica

APAN = Água Profunda do Atlântico Norte

$\mathrm{ACl}=$ Água Circumpolar Infeiror

ACS = Água Circumpolar Superior

LGM = Last Glacial Maximum 


\section{INTRODUÇÃO}

A caracterização das superfícies e subsuperfícies das áreas submersas é considerada de extrema importância, pois contribui tecnicamente para 0 planejamento das atividades humanas. Estas atividades são cada vez mais intensas e concentradas nestes ambientes complexos e sensíveis, que contêm muitos dos recursos naturais demandados pelo desenvolvimento econômico da sociedade moderna (Souza, 2006).

Um projeto de engenharia para um campo offshore requer a compreensão e a quantificação de todos os riscos potenciais. Entre eles, os escorregamentos no talude representam o principal risco. A avaliação dos riscos relacionados à estabilidade do fundo marinho é crítica para a exploração e produção de petróleo e representa um grande desafio às companhias petrolíferas. (Nadim et al., 2003).

O grande interesse exploratório em depósitos de águas profundas e ultra profundas justifica a importância de estudos geofísicos rasos e sedimentológicos na plataforma continental, talude e nas bacias marginais. A avaliação da estabilidade regional do talude e seu comportamento para fixação dos equipamentos para o sistema de produção e escoamento de petróleo é vital (Vicalvi, 1999).

A utilização de métodos geofísicos, especialmente métodos acústicos, em áreas submersas, possibilita uma visão mais ampla e contínua da superfície e subsuperfície investigada. Além disso, trata-se de métodos não 
destrutivos, sem a necessidade de penetração física no meio investigado (Souza, 2006).

Quando se analisa de forma sistemática a interação entre a dinâmica e a morfologia de fundo, com os métodos acústicos, pode-se estudar com alto grau de detalhamento, as feições da topografia submarina e da hidrodinâmica subjacente (Wewetzer e Duck, 1999; Wewetzer et al., 1999; Duck e Wewetzer, 2000; Lobo et al., 2002).

A sísmica de alta resolução empregada nos estudos estratigráficos fornece informações valiosas para a compreensão dos sistemas deposicionas, morfologia da plataforma durante as variações glacio - eustáticas. No entanto, até recentemente, a evolução geomorfológica dos sistemas deposicionais observados na plataforma sudeste tinha sido investigada apenas através dos levantamentos batimétricos convencionais (Reis et al., 2013).

Lima (2003) utilizou-se de informações de perfis batimétricos e de dados sísmicos de alta resolução obtidos por Sub Bottom Profiler de $3.5 \mathrm{kHz}$ e perfilador do tipo airgun, para estudar os mecanismos de formação de corpos sedimentares profundos e suas inter-relações, na margem continental SudesteSul do Brasil e bacia oceânica adjacente, para reconstruir a história da sedimentação na bacia durante o Cenozóico. A partir da análise destes dados, mapeou-se a coluna sedimentar cenozóica identificando contatos concordantes e discordantes entre as formações e localizando os depocentros das formações identificadas.

A plataforma continental norte do Estado de São Paulo constitui um dos setores da Zona Econômica Exclusiva Brasileira de maior atividade 
antrópica, porém, com um dos menores graus de conhecimento das características do fundo.

A Plataforma Continental estende-se das áreas rasas (dominadas por processos costeiros) ao limite superior do talude (dominado por processos oceânicos). A mesma constitui um ambiente complexo, no qual processos hidrodinâmicos e climáticos levam a uma enorme variabilidade em diferentes escalas de tempo e espaço (Castro Filho, 1996).

O Talude Continental é a província fisiográfica da Margem Continental que apresenta os mais elevados valores de declividade do fundo do mar. Nesta província estão presentes inúmeras feições, entre elas pockmarks, ondas de sedimento, contornitos e cânions submarinos, que são as maiores feições erosivas da margem.

Cânions submarinos são as principais características morfológicas que esculpem as margens continentais em todo o mundo (Shepard e Dill, 1966; Shepard, 1972) e constituem os principais canais para o transporte de sedimentos da plataforma para as bacias oceânicas, independentemente do ambiente tectônico (Carlson e Karl, 1988; Alonso e Ercilla, 2003; Lastras et al., 2009; Mountjoy et al., 2009). A maioria das características geomorfológicas observadas dentro dos cânions (i.e., terraços, cânions tributários, ravinas e vales) foram formadas durante o Pleistoceno e sutilmente modificadas no Holoceno (Obelcz et al., 2013).

Os cânions submarinos, juntamente com as diversas cicatrizes de remoção, estão associados a processos de movimentos de massa que são amplamente controlados pela geologia de subsuperfície e correntes 
geostróficas. No talude estes processos ocorreram preferencialmente durante os períodos de nível relativo de mar baixo (Kowsmann et al., 2002).

O papel das correntes de contorno na formação e construção de margens continentais é considerado de grande importância. As correntes profundas de fundo podem desenvolver localmente, grandes depósitos de sedimento. Os padrões de acumulação dos sedimentos sob controle destas correntes dependem de fatores que interagem entre si: intensidade da circulação profunda regional, morfologia do fundo, circulação geostrófica, abundância de suprimentos terrígenos e biogênicos, camadas nefelóides e profundidade da PCC (profundidade de compensação do carbonato) (Faugères e Stow, 1993).

Os contornitos são definidos como sedimentos depositados ou retrabalhados pela ação da corrente de fundo. Nos últimos anos há um crescente reconhecimento de que as correntes de contorno são importantes agentes no transporte e no processo de sedimentação em mar profundo. $O$ estudo de contornitos agora é considerado crucial para, pelo menos, três áreas de investigação: paleoceanografia; estudo de inclinação e estabilidade (avaliação de risco geológico); e exploração de hidrocarbonetos (por exemplo, Stow et al., 2002a; Rebesco., 2005, 2014).

Neste contexto insere-se o presente trabalho, buscando reconhecer a morfologia do fundo, padrões sedimentares e os agentes modeladores que atuam na área de estudo, na Bacia de Santos. 


\section{HIPÓTESE}

- Os cânions submarinos, se existentes, na área do estudo foram formados durante os períodos de nível relativo de mar baixo, sendo decorrentes da paleodranagem da plataforma continental.

- A plataforma externa sofre processo de erosão, ocasionada pela ação da Corrente do Brasil.

- As feições erosivas encontradas na região do talude são provenientes das correntes de contorno.

\section{OBJETIVO}

O objetivo do presente trabalho é compreender e estabelecer um modelo de evolução sedimentar, ao longo do Quaternário, para a plataforma continental externa e talude do ao largo de São Sebastião.

Pretende-se atingir os seguintes objetivos específicos:

1. Definir os padrões deposicionais da plataforma continental externa e talude e associá-los aos processos hidrodinâmicos.

2. Identificar feições erosivas (cânions, ravinas, canais, vales) na plataforma externa e no talude.

3. Identificar feições de deslizamentos de fluxo de massa. 


\section{4. ÁREA DE ESTUDO}

A área de estudo corresponde à plataforma continental e o talude, ao largo de São Sebastião - SP, localizada na bacia de Santos e delimitada pelas latitudes $23^{\circ} 30^{\prime} \mathrm{S}-26^{\circ} 00^{\prime} \mathrm{S}$ e longitudes $43^{\circ} 55^{\prime} \mathrm{W}-46^{\circ} 50^{\prime} \mathrm{W}$, conforme ilustrada na Figura 1.



Figura 1. Mapa ilustrando a Bacia de Santos e em retângulo preto a área de estudo. (modificado Reis et al. (2013)). 


\subsection{BACIA DE SANTOS}

A Bacia de Santos é classificada como bacia de margem passiva. A Bacia de Santos possui uma área total de mais de $350.000 \mathrm{~km}^{2}$, estendendo-se ao longo do litoral dos estados do Rio de Janeiro, São Paulo, Paraná e Santa Catarina. Ela se estende da costa até o limite exterior do Platô de São Paulo (profundidades superiores a $3500 \mathrm{~m}$ ). Para o norte, ela é separada da Bacia de Campos pelo Alto de Cabo Frio. Já ao sul, a Zona de Fratura Florianópolis, que define o alto Florianopolis, separa-a da Bacia de Pelotas (Gamboa e Rabinowitz 1981; Dias et al., 1994; Macedo, 1990) (Figura. 1).

A Bacia de Santos se estende por aproximadamente 800 quilômetros em uma tendência paralela à costa, seguindo direção NE-SW, e mais de 450 quilômetros em direção NW-SE. A oeste, a bacia é limitada pelas cadeias de montanhas que compreendem a Serra do Mar e a Serra da Mantiqueira (Milani 2000).

A fisiografia da margem continental é constituída pela Plataforma Continental, Talude e Sopé, onde está situado o Platô de São Paulo. A atual fisiografia se dá pela combinação de estruturas herdadas de processos tectônicos, halocinese e retrabalhamento dos sedimentos por processos de correntes de fundo e também pela circulação superficial no caso da plataforma continental (Rebesco et al. 2014). 


\subsection{EVOLUÇÃO TECTONICA}

A evolução tectônica da Bacia de Santos ocorre no mesmo contexto evolutivo das demais bacias da margem leste do Brasil. A Bacia de Santos tem sua origem associada aos primeiros pulsos tectônicos que ocasionaram a separação da América do Sul e África no Neocomiano, dividida em três supersequências: Rift, Pós-rift e Drift. (Fig. 2). A fase rift desenvolveuse no Cretáceo inferior (Hauteriviano e Barremiano), seguida de um período de transição (Cainnelli e Mohriak, 1999; Macedo, 1990).

O início da fase pós-rifte ocorreu durante o final do Aptiano ( $120 \mathrm{Ma}$ ), caracterizada por subsidência térmica flexural, seguida uma relativa estabilidade tectônica em um ambiente deposicional do tipo golfo alongado. Essas condições proporcionaram a deposição de extensas e espessas camadas carbonáticas (Formação Barra Velha) e evaporíticas (Formação Ariri). Os evaporitos são compostos predominantemente por halita, seguida por anidrita. Esses grandes depósitos de evaporitos datam de 113-112 Ma (Moreira et al., 2007; Macedo, 1990 ).

A fase drifte (deriva marinha) começou durante o Albiano ( 110 Ma), com o primeiro estágio de formação do Oceano Atlântico. A evolução da fase drift se deu com a ampliação do assoalho oceânico (abertura do Atlântico Sul), que criou condições marinhas profundas, afogando uma plataforma carbonática (Pereira e Macedo de 1990; Mohriak et al., 1995). A subsidência contínua da bacia foi acompanhada, no Cretáceo tardio, por uma enorme transferência de sedimentos continentais, principalmente influenciada pela inclinação flexural da margem, o que elevou as zonas costeiras, como a Serra 
do Mar e a Serra da Mantiqueira. Essa elevação gerou aumento no processo de erosão aumentando a carga sedimentar que preenchia a parte interna da bacia. Consequentemente, desenvolveu-se a halocinese, que perdura até os dias de hoje (Pereira e Feijó 1994; Almeida e Carneiro, 1998; Meisling et al. 2001;. Modica e Brush, 2004).

Os grandes volumes de sedimentos clásticos do Cretáceo Superior e Palaeógeno na porção central da Bacia de Santos devem ter sido transportados pelos principais sistemas fluviais na região, o Paraíba do Sul e do Tietê. Eles foram provavelmente responsáveis pela drenagem da Bacia de Santos, durante o final do Cretáceo antes da elevação do litoral (Meisling et al. 2001; Modica e Brush 2004).

Através das reativações tectônicas que ocorreram a partir do Eoceno em diante, ocorreu a reorganização dos sistemas de drenagem. Os sistemas foram capturados e desviados para a Bacia de Campos através da bacia do Paraíba do Sul. Como consequência, a plataforma tornou-se "faminta", ou seja, carente de aporte de sedimentos. (Karner e Driscoll, 1999; Modica e Brush, 2004). Assim no Eoceno, a plataforma recuou mais de $50 \mathrm{~km}$ em direção à costa, evoluindo para a arquitetura atual, com planícies costeiras estreitas e pequenos rios que drenam principalmente rochas cristalinas do PréCambriano (Milliman, 1978; Zembruscki, 1979; Zalan e Oliveira, 2005).

As evidências de tectonismo no Quaternário são relativamente restritas, embora haja indicativos de condicionamento tectônico mais recente na evolução da planície sedimentar de Cananéia-Iguape, no litoral sul paulista (Souza et al., 1996). Outra sugestão diz respeito à possível ocorrência de um nível de mar alto, com idade aproximada de 40.000 anos A.P., registrada para 
a região do Canal de São Sebastião, não concordante com as curvas isotópicas globais (Mahiques et al., 2011).

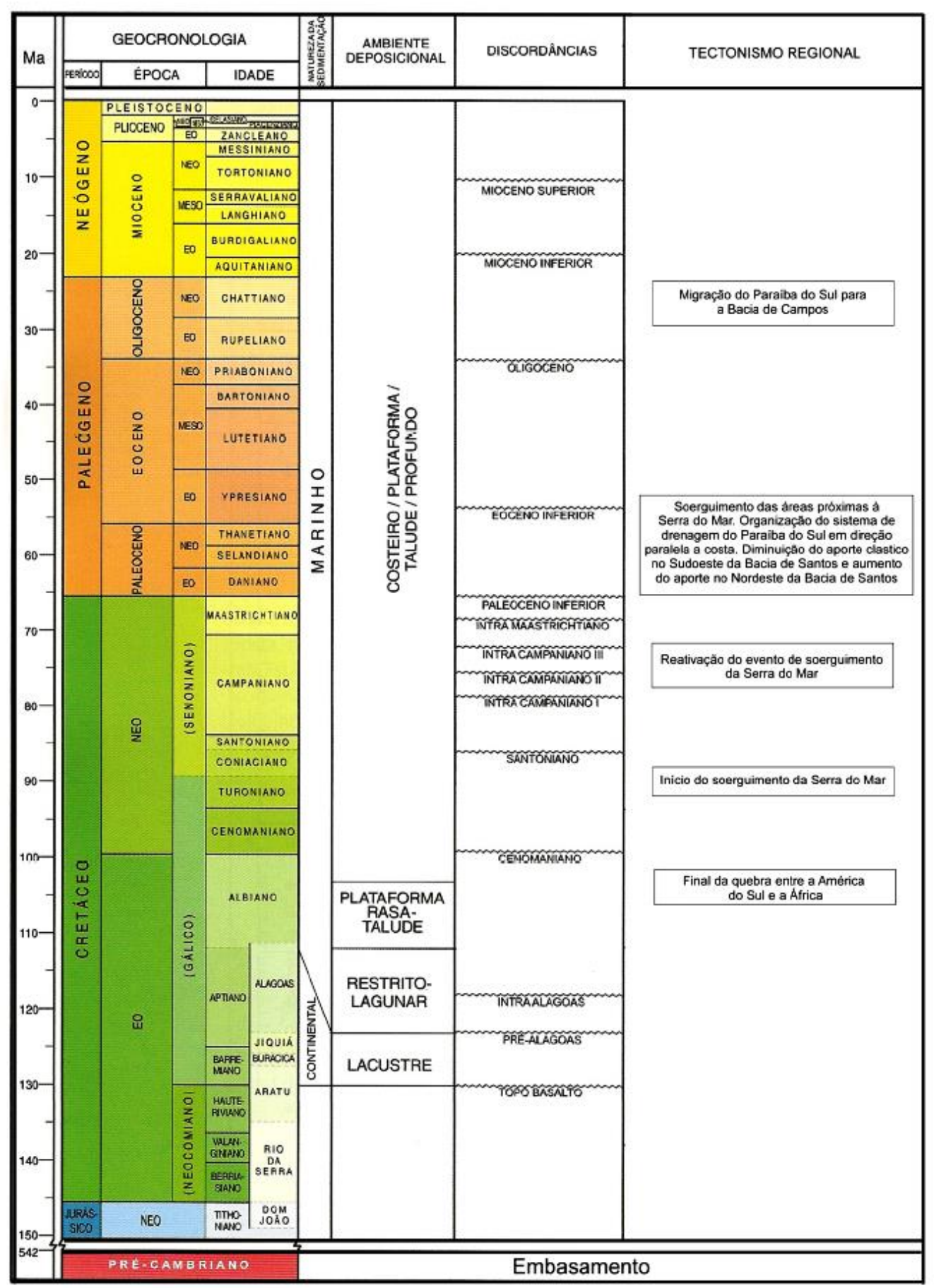

Figura 2. Tabela geológica modificada de Moreira et al. (2007) 


\subsection{GEOMORFOLOGIA E DISTRIBUIÇÃO SEDIMENTAR}

As planícies costeiras são estreitas, especialmente na região entre Rio de Janeiro e Santos, em função da ausência de grandes rios. Em direção ao sul e no extremo NE, o litoral desenvolve sistemas estuarinos (Paranaguá, Santos, Baía de Guanabara) e restingas (Marambaia, Cabo Frio). $\mathrm{Na}$ porção mais central predominam praias, encaixadas entre vales e montanhas pertencentes à Serra do Mar (Zembruscki, 1979; Reis et al. 2013).

A llha de São Sebastião constitui um notável marcador geomorfológico, não somente da linha de costa, como da plataforma continental. Nesta região ocorre uma mudança na direção geral da linha de costa, que passa de SW-NE, ao sul da llha de São Sebastião, para W-E, a norte. Também, ao norte da llha de São Sebastião, os recortes do litoral e a presença de várias ilhas, tornam mais complexa a geomorfologia regional (Fúlfaro et al., 1974).

As variações do nível relativo do mar constituem elemento importante na evolução das planícies costeiras, principalmente durante o Quaternário. A maioria dos estudos sobre quaternários da Bacia de Santos concentrou-se na investigação geomorfológica e distribuição de sedimentos superficiais oriundos das variações glácio-eustáticas (Kowsmann et al., 1979; Zembruscki, 1979; Côrrea et al., 1980; Dias et al., 1982; Alves e Ponzi, 1984; Mahiques et al., 2004; Mahiques et al., 2007).

Superpondo-se ao controle morfotectônico mesozóico-cenozóico, as variações do nível relativo do mar, principalmente as ocorridas durante o Quaternário superior, levaram ao remodelamento da plataforma continental, com fases de exposição e submersão de extensas áreas (Figura 3). Destes 
processos, cabe destacar o intenso fenômeno de dissecação e posterior submersão da plataforma continental ocorrido durante e após o Último Máximo Glacial (LGM) (Reis et al., 2013).

De uma forma geral, a plataforma continental esteve quase que totalmente exposta durante o máximo glacial de 18.000 anos A.P., com a linha de costa situada cerca de 130 metros abaixo do nível atual. Após este evento, o processo de submersão da plataforma apresentou pelo menos uma fase de estabilização do nível do mar, a 60 metros abaixo do nível atual, ocorrido há cerca de 11.000 anos (Vicalvi et al., 1979), além de um máximo transgressivo, ocorrido há cerca de 5.600 anos, no qual o nível do mar se encontrava a cerca de 4,5 metros acima do nível atual (Angulo et al., 2006). O processo de recuo do nível do mar, após esse máximo transgressivo, levou ao desenvolvimento de planícies costeiras, individualizadas entre as projeções do embasamento cristalino, espalhadas ao longo de quase todo o litoral sudeste brasileiro (Suguio e Martin, 1978).

Zembruscki (1979) descreve um modelo deposicional para os depósitos de areia e lamas transgressivas, onde as areias transgressivas foram recobertas por lamas da plataforma à medida que o aumento do nível do mar tornou o ambiente de deposição de baixa energia. Por fim, uma segunda unidade de lamas, oriunda da plataforma, teria sido depositada na fase de mar quase estacionário, ao término da transgressão. Esse padrão de deposição não teria ocorrido na plataforma externa deixando descobertas as areias e biodetritos. Essa diferença no padrão pode ser atribuída à alta energia característica da borda da plataforma e à retenção dos sedimentos finos em ambientes lagunares e estuarinos costeiros (Southard e Stanley, 1976). 




Figura 3. Compilação das curvas da variação do nível médio do mar baseado na razão isotópica $\delta^{18} \mathrm{O}$ para plataformas continentais (Reis et al. 2013).

\subsubsection{PLATAFORMA CONTINENTAL}

A largura da plataforma continental apresenta variações médias entre $100 \mathrm{~km}$ e $200 \mathrm{~km}$ de largura (Figura 1). Nas proximidades de Cabo Frio, ela apresenta a menor largura, com cerca de $70 \mathrm{~km}$. A atual quebra da plataforma está situada próxima à isóbata de $200 \mathrm{~m}$, geralmente marcada por uma passagem suave para o talude, com perfil convexo. Apenas no centro e nas partes mais orientais da bacia a quebra apresenta uma inclinação mais 
acentuada, coincidindo com a maior inclinação da bacia, com uma inclinação média $3^{\circ}$ (Figueiredo Jr. e Tessler 2004). A quebra da plataforma apresenta padrão irregular e exibe grandes reentrantes e algumas protuberâncias no talude superior, principalmente entre o Cabo Frio e a ilha de São Sebastião. Essas irregularidades, possivelmente estão associadas à ação de correntes de contorno (Duarte e Viana, 2007).

Nas proximidades da área de estudo a plataforma apresenta um baixo gradiente de inclinação e sofre uma ação de média a alta energia, afetada pela passagem de sistemas frontais, principalmente no inverno. A plataforma sofre influência de micro-maré, onde a onda de maré apresenta maior forçante no sentido transversal à costa (Alves, 1992).

A profunda diferença morfológica, entre os setores a norte e a sul da llha de São Sebastião, reflete-se, também, nos processos sedimentares de plataforma. Esta diferenciação condiciona a ação dos agentes oceanográficos nos dois setores. A sul da llha de São Sebastião, a configuração da linha de costa e o paralelismo das isóbatas levam a uma ação mais efetiva dos trens de ondas sobre a plataforma interna e à não deposição de sedimentos pelíticos na área. Por outro lado, a complexidade dos recortes da linha de costa e a presença de várias ilhas na plataforma interna, no setor a norte da llha de São Sebastião, fazem com que os processos de interação de ondas com o fundo sejam atenuados e favorecendo a deposição de lamas (Mahiques e Souza, 1995; Mahiques et al., 2004; Mahiques et al., 2007; Mahiques et al.,2008).

$\mathrm{Na}$ região da plataforma média, predominam sedimentos lamosos, principalmente a partir dos $100 \mathrm{~m}$ de profundidade. Algumas regiões há presença de faixas, onde ocorrem de areias médias a grossas (Figura 4). $\mathrm{Na}$ 
região da plataforma interna, existe uma tendência de aumento da fração mais grosseira no sedimento e entre as isóbatas de 100 e 150 metros verifica-se a presença de uma faixa carbonática (Mahiques et al., 2002).

Com relação à composição dos sedimentos, observa-se o predomínio de sedimentos litoclásticos na região ao sul do Estado de São Paulo, enquanto que os bioclásticos tendem ao aumento de São Paulo em direção ao NE da bacia. Os sedimentos bioclásticos concentram-se mais nas partes profundas, enquanto os litoclásticos estão nas áreas mais rasas. Os bioclásticos apresentam faixas maiores e mais contínuas ao norte (Figura 5). Os bioclastos ao norte da bacia são representados por maior ocorrência de algas calcárias do tipo rodolitos, enquanto que ao sul são representados pelos concheiros (Figueiredo Jr e Tessler, 2004).

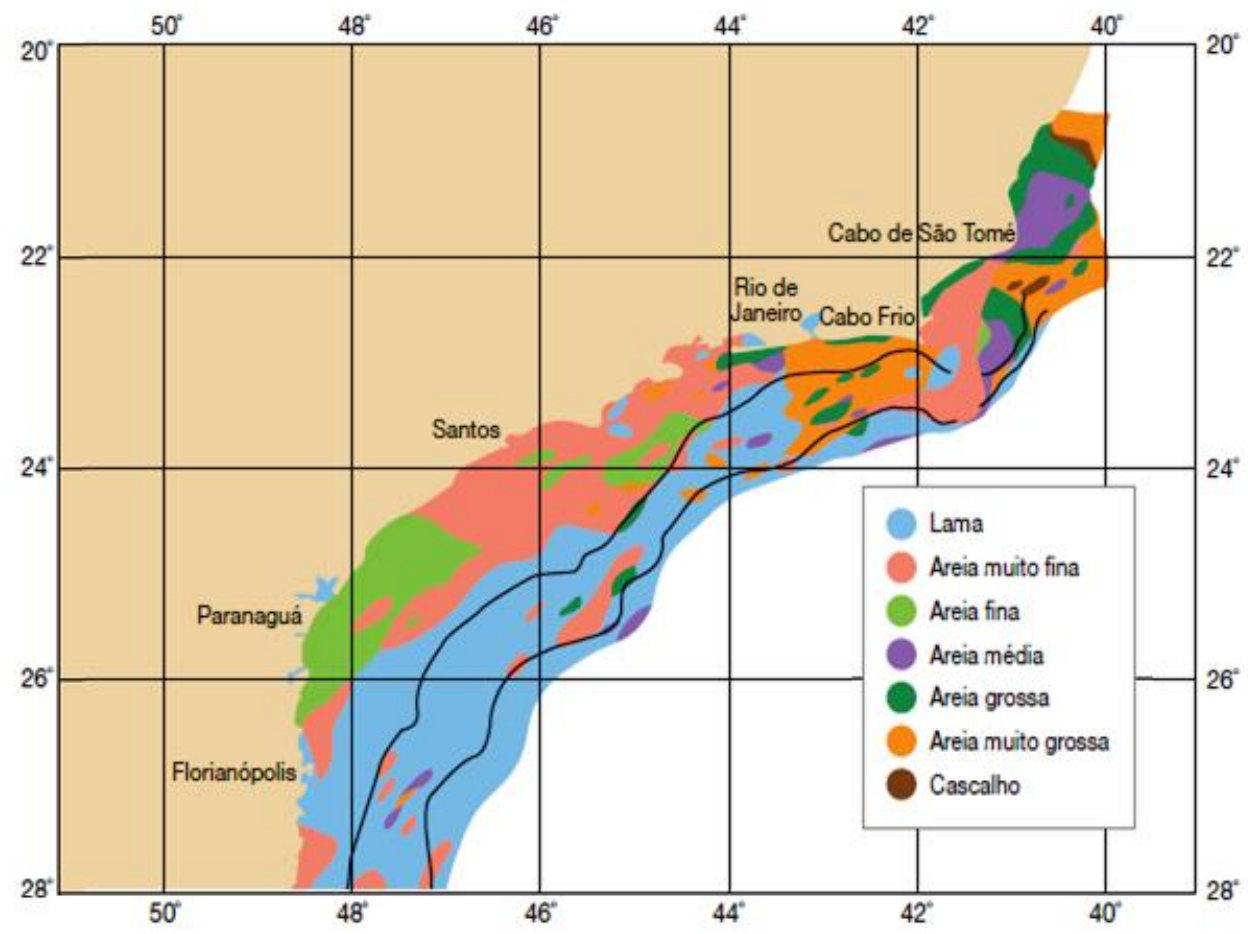

Figura 4. Mapa granulométrico da distribuição de sedimentos na Bacia de Santos (modificado Figueiredo Jr e Tessler, 2004). 


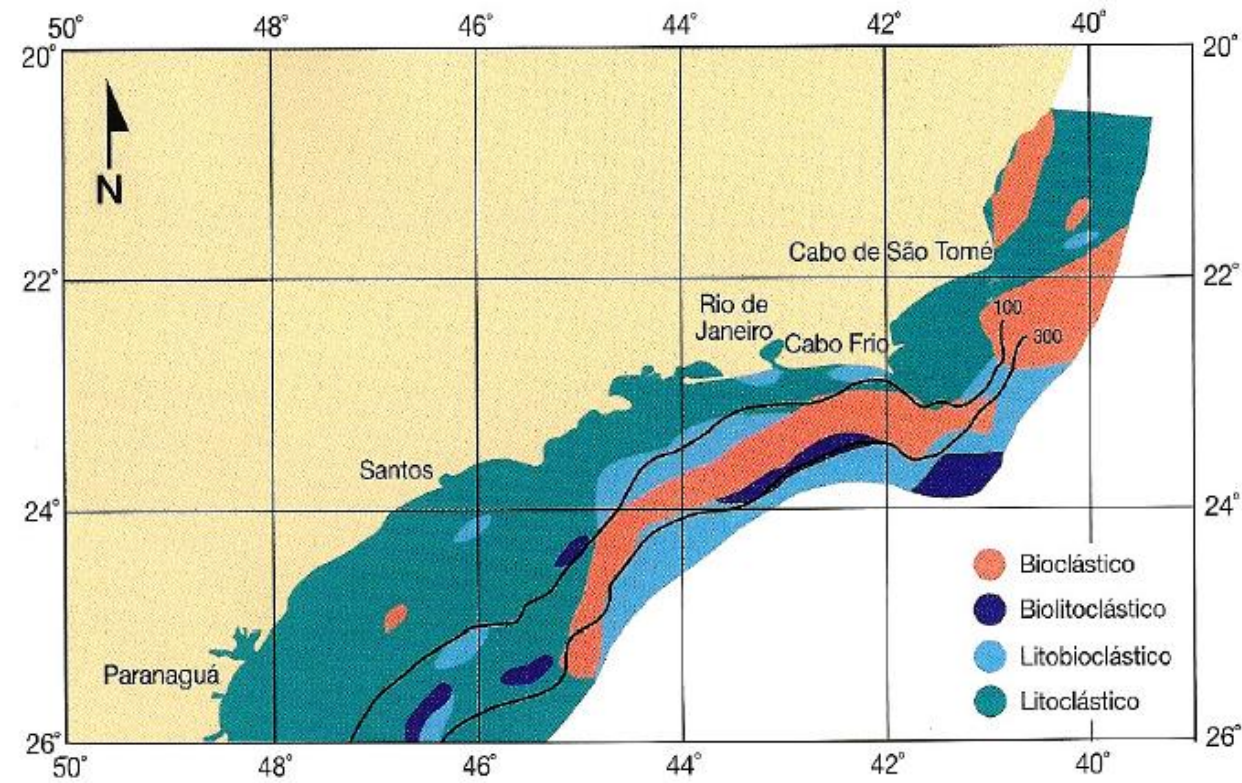

Figura 5. Mapa da composição sedimentar na Bacia de Santos (modificado Figueiredo Jr e Tessler, 2004).

\subsubsection{TALUDE CONTINENTAL}

Em termos gerais, o talude apresenta uma inclinação suave na sua parte superior (a partir da quebra da plataforma até $1000 \mathrm{~m}$ ) e mais íngreme conforme ocorre o aumento da profundidade. A base do talude na região ocorre entre $1800 \mathrm{~m}$ e $2200 \mathrm{~m}$, ficando mais rasa em direção ao norte da bacia.

Através dos perfis gerados pelo programa Revizee (Figuras 6 e 7) podese observar que os maiores gradientes de talude estão localizados nos extremos da área de estudo, principalmente ao norte, e gradientes bem mais suaves nas porções mais centrais. As porções de maior declividade estão relacionadas com taludes mais irregulares, que podem ser resultado do desenvolvimento de cânions ou de movimentos de massa (Figueiredo Jr e Tessler, 2004). 


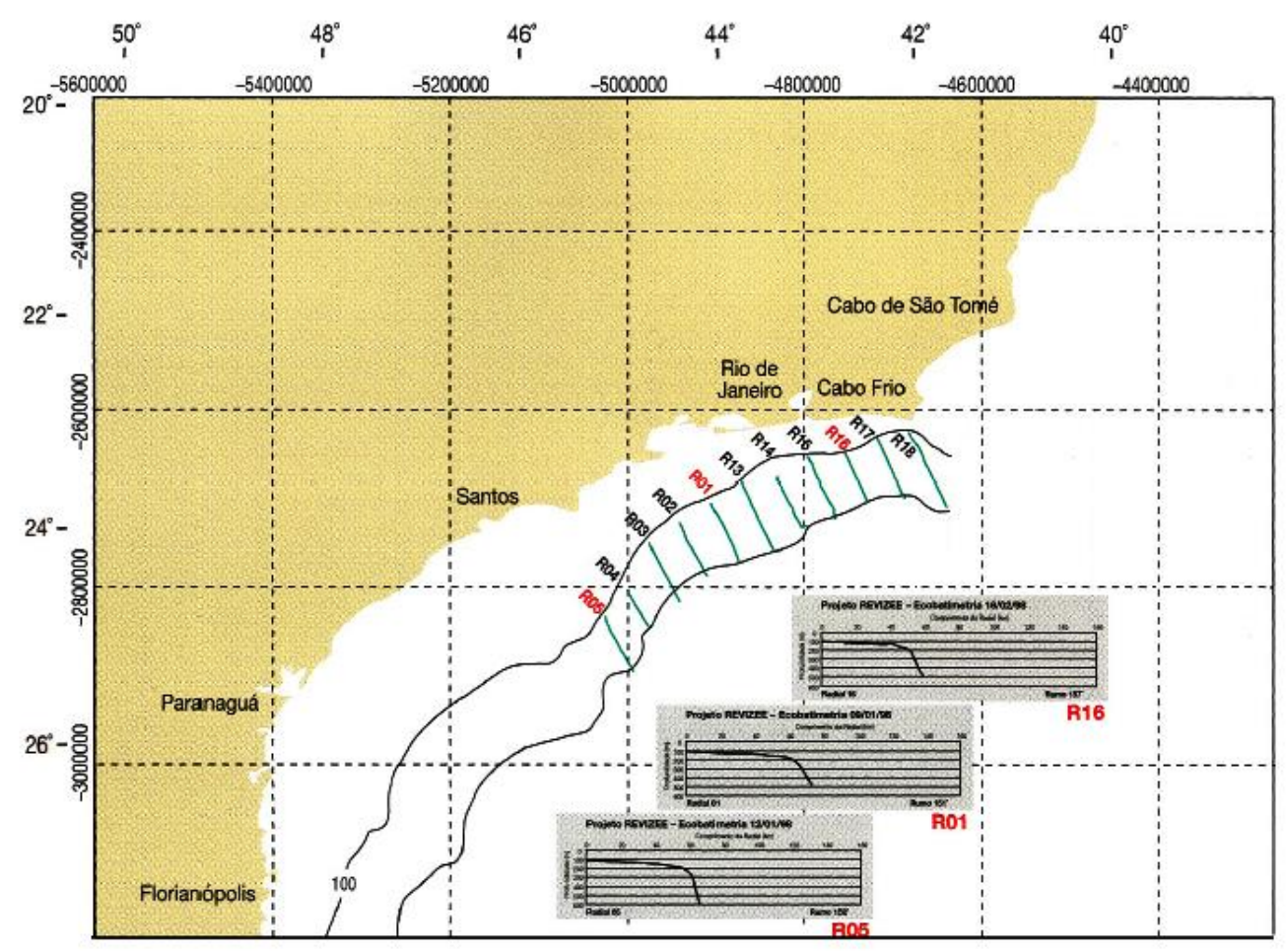

Figura 6. Mapa demonstrando a localização de alguns perfis batimétricos da Bacia de Santos obtidos pelo programa Revizee (modificado Figueiredo Jr e Tessler, 2004).


Figura 7. Perfis batimétricos na porção nordeste da Bacia de Santos (Figueiredo Jr e Tessler, 2004). 
A cerca de $1.500 \mathrm{~m}$ de profundidade verifica-se a presença de um canal paralelo ao talude, encaixado sobre a Falha de Cabo Frio. A falha de Cabo Frio foi resultado da combinação de tectônica distensiva, principalmente durante o grande aporte sedimentar, a partir do Santoniano, gerando a progradação de cunhas siliciclásticas, deslocando o sal em direção às partes mais profundas da bacia, gerando estruturas do tipo rollover. Com a movimentação da falha, houve a formação de um gap lateral da seção albiana, de cerca de $25 \mathrm{~km}$ de largura, ao longo de todo o bloco baixo da falha (Demercian et al., 1993; Mohriak et al., 1995; Szatmari et al., 1996; Ge et al., 1997)

Abaixo dos $1500 \mathrm{~m}$ observa-se no talude um decréscimo na inclinação e a região começa a sofrer uma grande influência da halocinese, com a criação de um intrincado padrão de mini-bacias, elevações topográficas e afloramento de diápiros de sal (Moreira et al., 2007; Caldas, M.F. e Zalán, P.V. 2009).

Duarte e Viana (2007) descrevem a presença de um canal, próximo a $1500 \mathrm{~m}$ de profundidade, paralelo ao talude que possui mais de $200 \mathrm{~km}$ de extensão. Esse canal descrito como estreito, é chamado de Canal de Santos, possuindo aproximadamente $2 \mathrm{~km}$ de largura e $100 \mathrm{~m}$ de profundidade, está associado à presença da Falha de Cabo Frio.

Através de registros sísmicos ao longo da porção centro-leste da Bacia de Santos, a partir da quebra da plataforma até profundidades superiores a 2000 m, é possível observar evidências de fortes correntes de fundo que influenciam o padrão de sedimentação regional. Essas correntes são observadas desde o Cretáceo inferior, indicando um forte aumento desde o final do Paleógeno até os dias atuais (Duarte e Viana, 2007). 


\subsection{MASSAS DE ÁGUAS E CIRCULAÇÃO}

\subsubsection{ESTRUTURA VERTICAL DE MASSAS DE ÁGUA}

A região de estudo encontra-se sob a influência de várias massas d'águas. Até os primeiros $3500 \mathrm{~m}$ de coluna de água, encontram-se a Água Tropical (AT), a Água Central do Atlântico Sul (ACAS), a Água Intermediária Antártica (AIA), a Água Circumpolar Superior (ACS), a Água Profunda do Atlântico Norte (APAN) e a Água Circumpolar Inferior (ACl).

A AT é considerada uma massa de água quente $\left(>20^{\circ} \mathrm{C}\right)$, com salinidade superior a 36,2 ao largo do sudeste brasileiro e ocupa principalmente os primeiros 200 metros, sendo transportada para o sul pela Corrente do Brasil (CB). A ACAS é encontrada logo abaixo, apresentando temperaturas maiores que $8,7^{\circ} \mathrm{C}$ e menores que $20^{\circ} \mathrm{C}$, e salinidades entre 34,66 e 36,20 (Tabela 1 ). A ACAS estende-se até 600 metros e também é transportada pela CB, fluindo para o sul na bacia de Santos (Stramma e England, 1999; Memery et al., 2000).

Subjacente à ACAS, encontra-se a AIA com seus limites termohalinos de $8,72^{\circ} \mathrm{C}$ a $3,46^{\circ} \mathrm{C}$ de temperatura e $34,66-34,42$ para salinidade, ocupando profundidades entre $600 \mathrm{~m}$ e $1200 \mathrm{~m}$. Abaixo observa-se a presença da ACS que apresenta densidade semelhante à da APAN. A ACS é formada da mistura entre a Agua Circumpolar (ACP) e a APAN que aflora na região da Divergência Antártica e ocupa profundidades próximas a 1100 a 1300. A APAN é caracterizada por valores de temperatura entre $3,31^{\circ} \mathrm{C}-2,04^{\circ} \mathrm{C}$ e salinidades 
de $34,59-34,87$, ocupando profundidades entre $1300 \mathrm{~m}$ e $3600 \mathrm{~m}$, ao largo do sudeste brasileiro (Stramma e Peterson, 1990).

Tabela 1. Limites termohalinos e espessuras das massas de água na região.

\begin{tabular}{cccc}
\hline Massa de água & Temperatura $\left({ }^{\circ} \mathrm{C}\right)$ & Salinidade & Espessura $(\mathrm{m})$ \\
\hline AT & $>20$ & $>36,20$ & $0-142$ \\
ACAS & $20,00-8,72$ & $36,20-34,66$ & $142-567$ \\
AIA & $8,72-3,46$ & $34,66-34,42$ & $567-1060$ \\
ACS & $3,46-3,31$ & $34,42-34,59$ & $1060-1300$ \\
APAN & $3,31-2,04$ & $34,59-34,87$ & $1300-3260$ \\
\hline
\end{tabular}

Na Plataforma Continental externa, a estratificação vertical é fortemente influenciada pelo padrão de circulação atmosférica. A dinâmica de massas d'água na plataforma continental da área de estudo é dominada pelos deslocamentos de duas massas, que apresentam sazonalidade acentuada. Entre novembro e março ocorre com maior frequência a intrusão, pelo fundo, da Água Central do Atlântico Sul (ACAS), em direção à linha de costa, induzindo o deslocamento da Água Costeira (AC), mantendo a Água Tropical (AT) relativamente distante do litoral (Castro Filho et al., 1987).

Segundo Mahiques et al. (1999) o deslocamento da AC em direção a porções mais externas da plataforma, nos meses de verão, é o principal responsável pela exportação e deposição de matéria orgânica de natureza terrígena, em áreas mais profundas. 


\subsubsection{CIRCULAÇÃO}

A circulação atuante na área de estudo é composta pela Corrente do Brasil (CB), a Corrente de Contorno Intermediária (CCl) e Corrente de Contorno Profunda (CCP).

A Corrente do Brasil (CB) está enquadrada como corrente de contorno oeste de superfície, que flui em direção ao sul, fechando o Giro Subtropical do Atlântico Sul. A CB é considerada rasa, quente e alta salinidade. Ela é constituída pela AT e ACAS, fluindo junto à quebra da plataforma (Figura 8). Ao sul da Bacia de Santos, a CB apresenta extensão vertical de mais de $500 \mathrm{~m}$ e $100 \mathrm{~km}$ de largura. Ela transporta volume de água de $-5,75 \pm 1,53 \mathrm{~Sv}$ e pode atingir velocidades máximas de $0,59 \mathrm{~ms}^{-1}$ (Evans e Signorini, 1985; Stramma e England 1999).

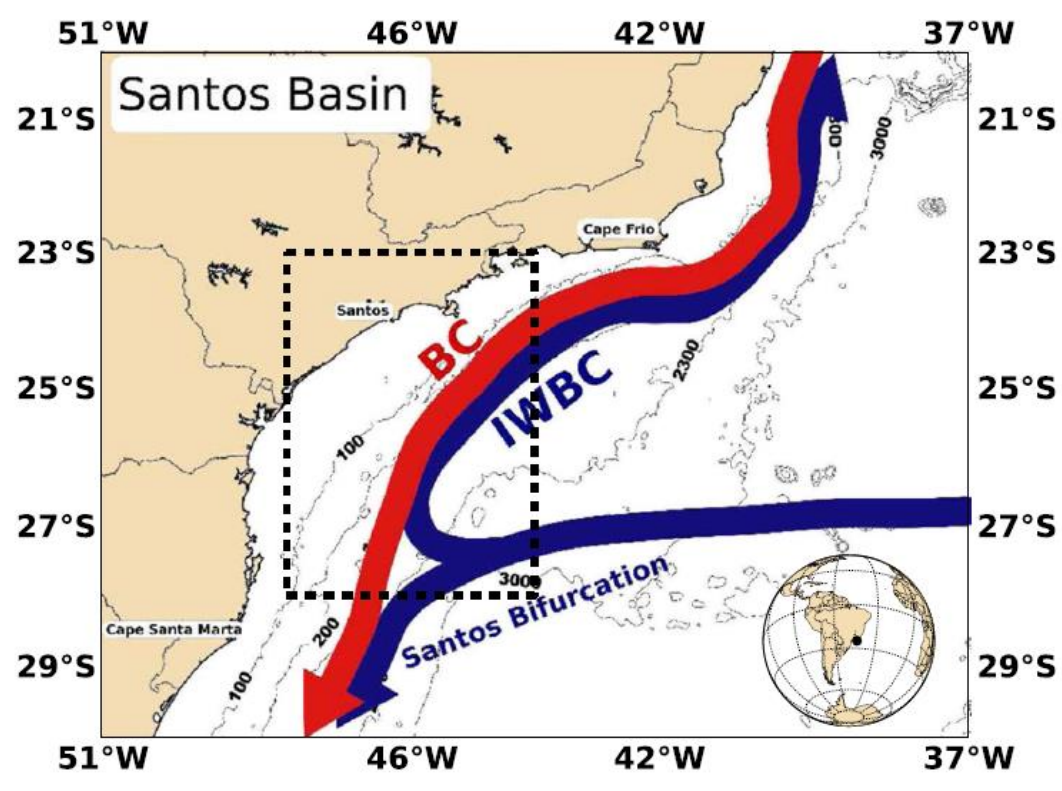

Figura 8. Esquema do padrão de circulação da Corrente do Brasil (BC - vermelho) e da Corrente de Contorno Intermediária (IWBC - Azul) (Biló et al. 2014). 
A formação de vórtices anticiclônicos pela Corrente do Brasil (CB) ao largo do Cabo Frio já foi por diversas vezes descrita na literatura (Garfield, 1990). Os largos meandros característicos na região e o cisalhamento vertical associado à $\mathrm{CB}$ e à $\mathrm{AIA}$ subjacente sugerem que o processo de geração do vórtice esteja associado à instabilidade baroclínica (Signorini, 1978).

Mais ao sul, já dentro do Embaiamento de São Paulo, a CB volta a exibir um comportamento instável. Nesta região ocorre a formação de ciclones e anticiclones, menores em tamanho que os do Cabo Frio e que, aparentemente, não se desprendem do eixo principal da CB (Campos et al., 1995; 1996). Acredita-se que os vórtices ciclônicos induzam uma ressurgência de quebra de plataforma, trazendo ACAS para regiões rasas e com prováveis e importantes consequências na produtividade primária da região e na ressuspensão de sedimentos previamente depositados (Mahiques et al. 2005).

Observações de temperatura da superfície do mar através de imagens de satélite demonstram o padrão sinuoso/vórtice da Corrente do Brasil (CB) na Bacia de Santos (Figura 9). Esta imagem indica a penetração frequente da Corrente do Brasil na plataforma, que poderia implicar na configuração sinusoidal da quebra da plataforma (Duarte e Viana, 2007). 


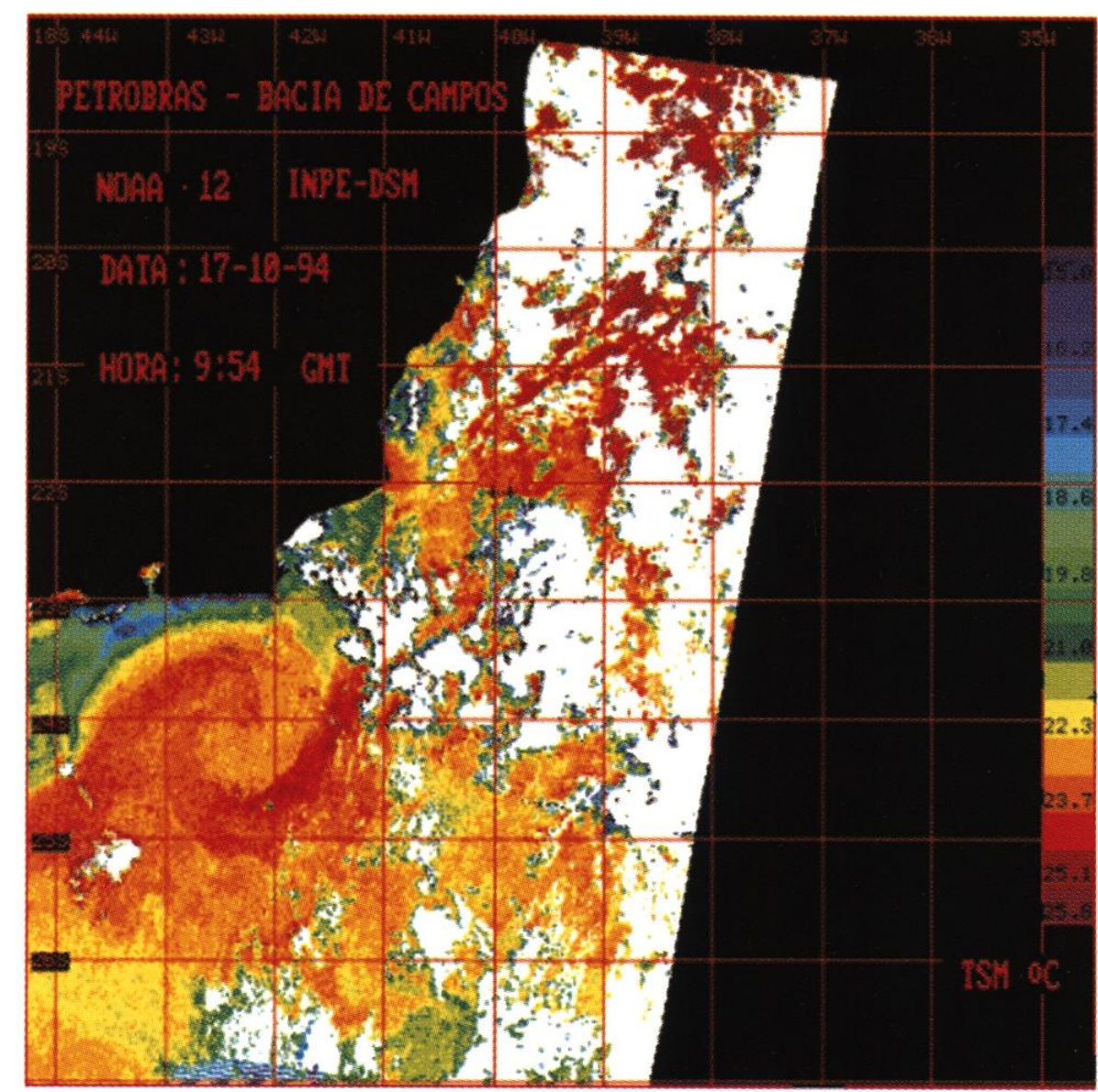

Figura 9. Imagem do satélite (Landsat NOAA-12) ilustrando o meandramento da Corrente do Brasil.

Abaixo da CB, em porções intermediárias do talude continental, desloca-se a Corrente de Contorno Intermediária (CCI). Nela estão englobadas as massas de água AIA e ACS. Na Bacia de Santos em latitudes próximo a $27^{\circ} \mathrm{S}$ ocorre a bifurcação da $\mathrm{CCl}$, onde uma parcela flui para nordeste em direção à Bacia de Campos e outra flui para Sul (Figura 8). Ao analisar o ramo que flui para nordeste na bacia, a CCl possui espessura de até 1000 metros, largura de aproximadamente $60 \mathrm{~km}$, velocidades de $\sim 0.22 \mathrm{~ms}^{-1}$ e transporte de volume de 4,11 $\pm 2,01 \mathrm{~Sv}$ (Boebel et al., 1999; Stramma e England, 1999; Biló et al., 2014). 
Logo abaixo da $\mathrm{CCl}$, com aproximadamente dois quilômetros de coluna de água, observa-se a Corrente de Contorno Profunda (CCP), que transporta a APAN e novamente flui para o sul (Figura 10) (Stommel, 1958; Stramma e England, 1999).

A presença do Platô de São Paulo, ao largo da margem continental sudeste, resulta no deslocamento da CCP para porções mais interiores da bacia oceânica (Godoi, 2005). Assim, pode-se assumir que a área objeto de estudo, compreendida entre a plataforma externa e o talude continental, acha-se sob o efeito direto da CB e CCI. Essas duas correntes possuem um padrão de escoamento essencialmente baroclínico e marcado por uma única inversão de sentido das correntes na vertical (Silveira et al. 2004).



Figura 10. Representação da circulação da CCP (Corrente de Contorno Profundo) nas profundidades 1300 - 3260 m (Stramma e England, 1999). 


\section{MATERIAIS E MÉTODOS}

A bordo do navio oceanográfico Alpha Crucis foram realizados dois cruzeiros com objetivo de caracterizar a aspectos geológicos da superfície e subsuperfície da plataforma externa e talude. O primeiro cruzeiro, pertencente ao projeto NAP-GEOSEDEX, foi realizado entre os dias 20 a 28 de fevereiro de 2013. O segundo cruzeiro foi realizado, entre os dias 03 a 08 de agosto de 2013. Ao todo foram executadas mais de $1.130 \mathrm{~km}$ de linhas batimétricas e de sísmica rasa, conforme ilustrado na figura 9.

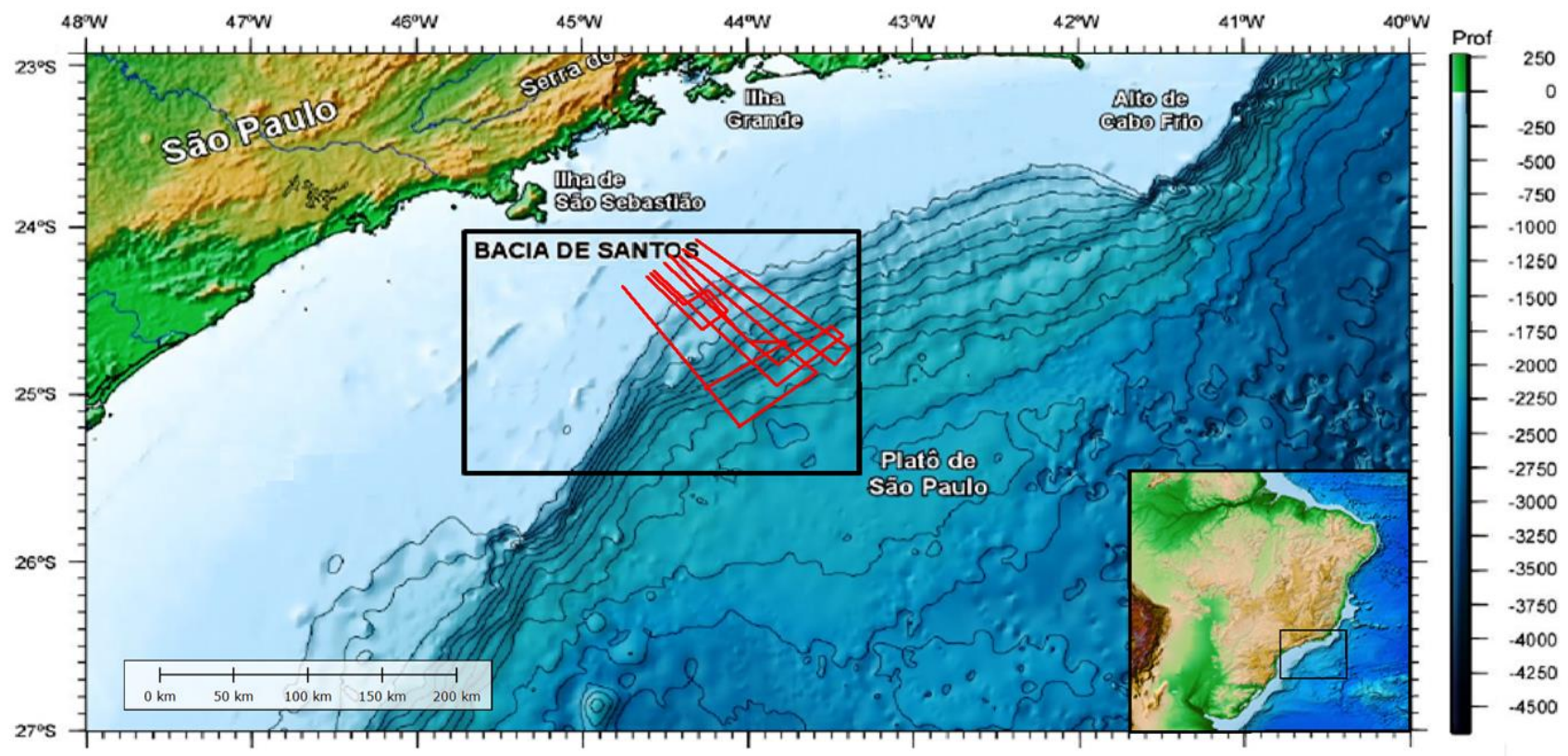

Figura 9. Mapa da localização das linhas que foram realizadas a batimetria e a perfilagem sísmica. 
Todos os dados geofísicos foram georeferenciados através do sistema DGPS (Differential Global Position System). Antes do inicio da sondagem foram ajustados todos os offsets dos transdutores em relação à antena, garantindo que todos os dados apresentassem coordenadas geográficas corretas.

\subsection{VELOCIDADE DE SOM NA ÁGUA}

Para obter os valores da velocidade do som na coluna d'água utilizou-se dados de batitermógrafos descartáveis XBT (Expendable Bathythermograph). Durante os cruzeiros foram lançados 53 XBT, conforme ilustrado na Figura 10. Os modelos utilizados para perfilagem da coluna d'água foram os T5 e T7, acoplados ao software de processamento Sippican Mark 21.

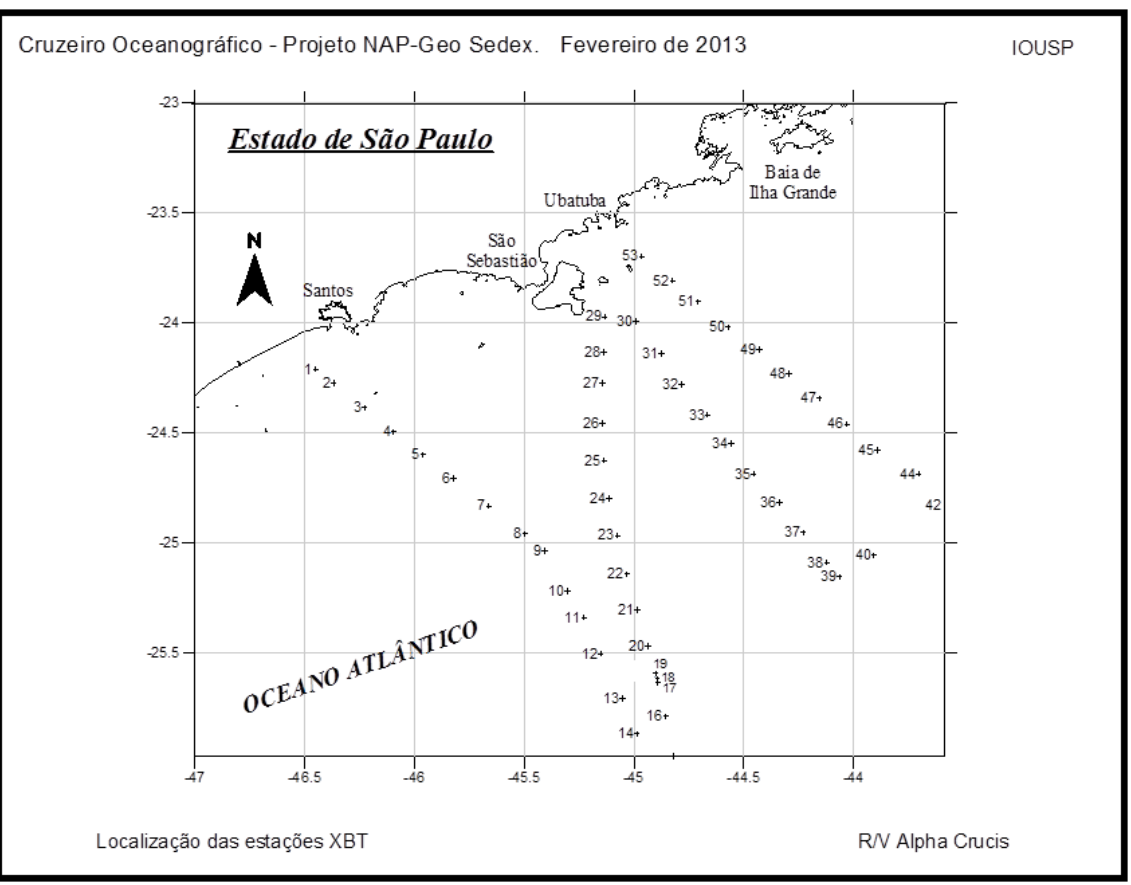

Figura 10. Mapa com a localização dos pontos da perfilagem com XBT. 


\subsection{BATIMETRIA MONOFEIXE}

Os dados batimétricos foram adquiridos através da ecossonda monofeixe modelo EA 600 da Kongsberg. A ecossonda operou com frequências de $12 \mathrm{kHz}$ e $38 \mathrm{kHz}$.

Os dados brutos foram primeiramente transformados no formato $\mathrm{XYZ}$. Posteriormente foram eliminados erros (spikes) e os dados foram plotados em seções. Os softwares utilizados para o tratamento e a para plotar os perfis foram Global Mapper (Blue Marble Geographics) e Excel (Microsoft).

\subsection{PERFILAGEM SÍSMICA DE ALTA RESOLUÇÃo}

Para a obtenção dos dados de sísmica de alta resolução utilizou-se o SBP (sub-bottom profiler) CHIRP 3260 do fabricante Knudsen. O sistema CHIRP operou com frequência de $3,5 \mathrm{kHz}$, com potência superior a $2 \mathrm{~kW}$ e ângulo cônico dos transdutores de aproximadamente $27^{\circ}$. O aplicativo utilizado para aquisição dos dados sísmicos foi o EchoControl Client for Windows (Knudsen Engineering). 


\subsubsection{PROCESSAMENTO}

Após a aquisição, os dados foram primeiramente transformados para 0 formato XYZ. Posteriormente utilizou-se o software MDPS (Meridata Finland) para o tratamento e interpretação. Abaixo segue o fluxograma, no qual os dados foram submetidos:

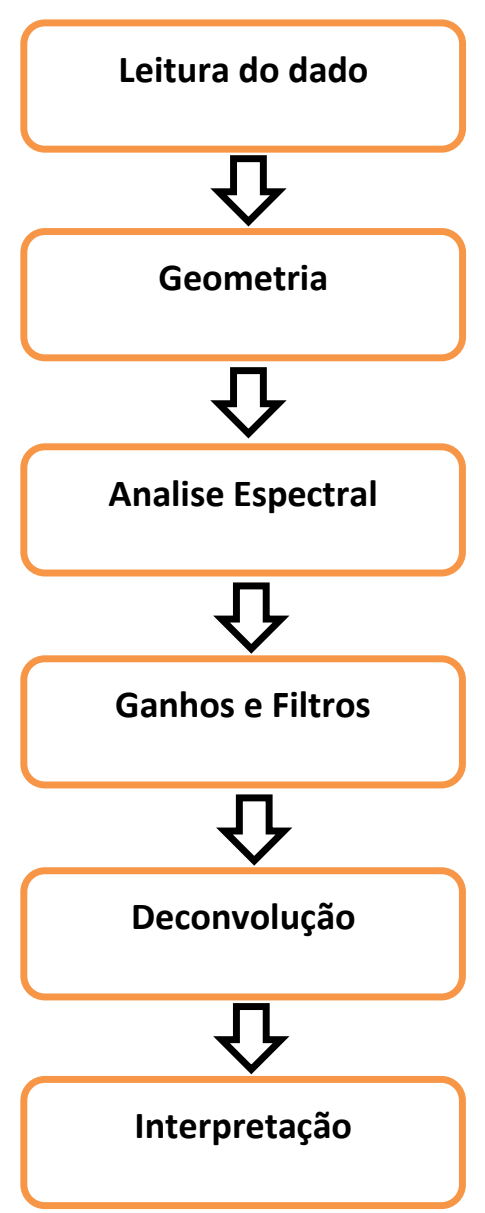

- Leitura do Dado - Reformatação dos dados brutos para formato SEGY;

- Geometria - Distância entre traços e localização por coordenadas XY, correção com a topografia. Inserção/extração de traços, remoção da 
lâmina d'agua (quando conveniente), corte do tempo duplo, união arquivos, entre outras;

- Analise Espectral - Visualização e correlação dos espectros de amplitude, tempo, frequência, número de onda e correção das amplitudes;

- Ganhos e Filtros - Compensação da divergência geométrica e decaimento da energia; filtros passa-banda; funções de ganho; ganho AGC; ganho manual (y);

- Deconvolução - Deconvolução preditiva: atenuação de múltiplas do fundo do mar;

- Interpretação da Seção Sísmica - Identificação das informações geológicas contidas no dado de alta resolução.

Para correção da velocidade do som na água utilizou-se os dados dos perfis do XBT. Já para correção da velocidade do som no sedimento, adotou-se a velocidade padrão de $1600 \mathrm{~m} / \mathrm{s}$. Essa velocidade foi adotada em função de outros autores na literatura terem utilizados, facilitando a comparação dos dados (Lobo et al. 2005). 


\section{RESULTADOS}

Os dados batimétricos e sísmicos foram analisados e confeccionadas figuras para avaliar as variações morfológicas locais e espaciais ao longo da área de estudo. Na figura 11, visualizam-se as linhas sondadas e suas nomenclaturas ( $\mathrm{S}$ - seções e $\mathrm{T}$ - Transversais).

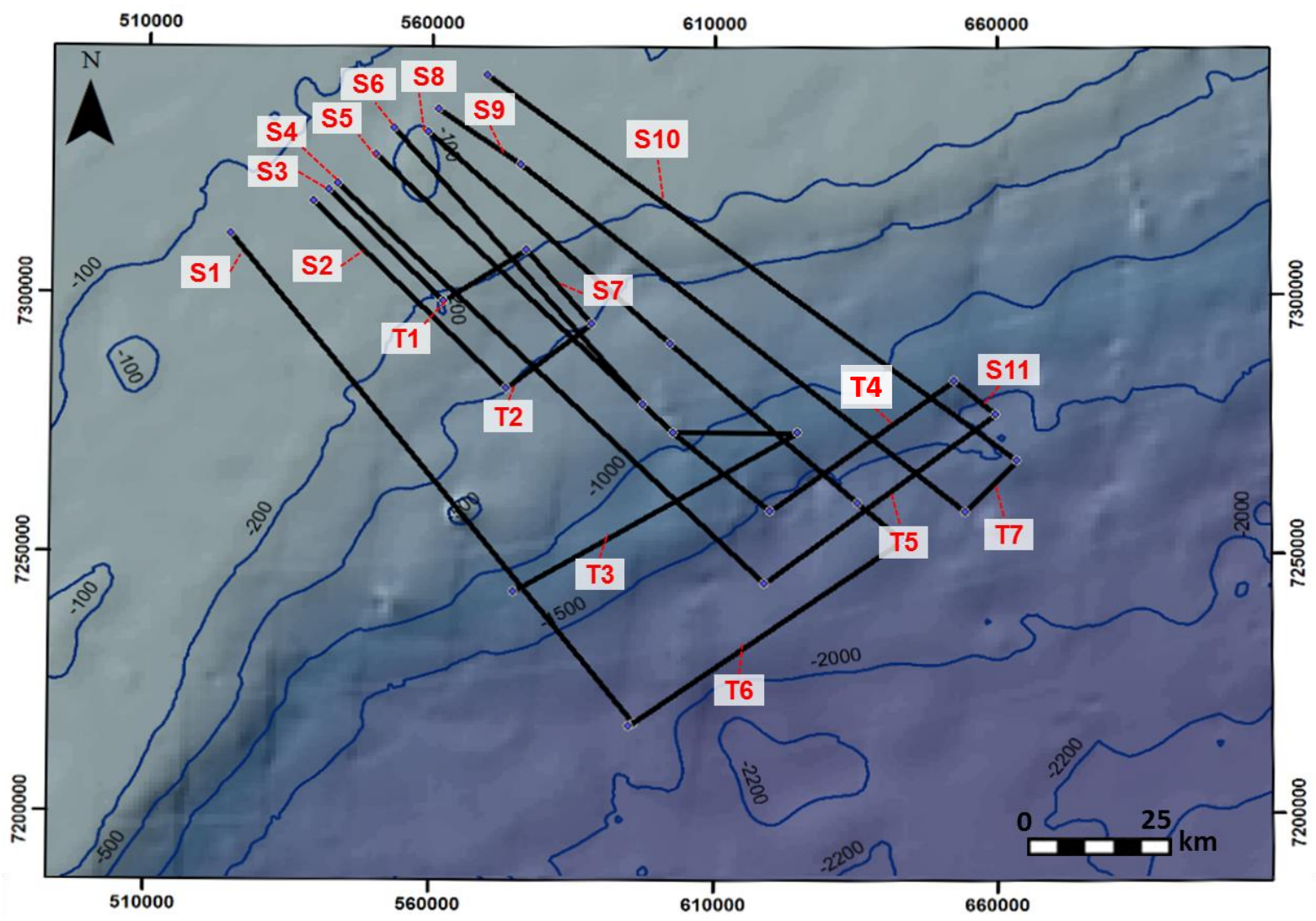

Figura 11. Mapa com as linhas sondadas e a nomenclatura adotada.

Devido à grande quantidade de dados gerados pela batimetria e sísmica, optou-se em setorizar a apresentação dos resultados, ilustrando os principais registros da área de estudo. 
$\mathrm{Na}$ descrição abaixo, os resultados foram subdivididos em: Plataforma Externa, Talude superior e Talude inferior.

Abaixo seguem descritos os critérios adotados para a subdivisão:

- Plataforma Continental Externa: está compreendida entre o início dos registros, próximo à isóbata de 100 metros, até a quebra da Plataforma;

- Talude Superior: está compreendido entre a quebra da plataforma até a isóbata 600 metros. Sob o ponto de vista hidrodinâmico corresponde, na área, à transição entre a Corrente do Brasil e a Corrente de Contorno Intermediária;

- Talude Inferior: está compreendido entre 600 metros e o término dos registros, normalmente próximos à isóbata de 2000 metros.

\subsection{PLATAFORMA CONTINENTAL EXTERNA}

A Plataforma Continental Externa, ao largo da ilha de São Sebastião, apresenta variações morfológicas de expressão, tanto local, como regional, no sentido sudoeste - nordeste.

O setor estudado da plataforma externa possui comprimento médio de $30 \mathrm{~km}$ e compreende uma largura lateral de $60 \mathrm{~km}$. As seções batimétricas e sísmicas estão orientadas aproximadamente a $140^{\circ}$ de azimute. A plataforma apresentou variações entre $0.02^{\circ}$ a $0.13^{\circ}$ no gradiente. As seções 9 e 10 , a nordeste, apresentaram os menores valores de inclinação $\left(0.02^{\circ}\right.$ e $\left.0.03^{\circ}\right)$. Já as 
seções 2 e 3 são as que possuem os maiores gradientes $\left(0.09^{\circ}\right.$ e $\left.0.13^{\circ}\right) . \mathrm{Na}$ Tabela 2 verificam-se o comprimento sondado, gradiente e a profundidade da quebra da plataforma de cada perfil batimétrico.

Nos registros da plataforma visualiza-se um fundo totalmente irregular, corrugado, canais e depressões erosivas com extensões e profundidades variadas. Observam-se inúmeras montiformas, escarpas na plataforma, destacando a presença de montiforma, principalmente nas proximidades das isóbatas de 130 e 142 metros e também uma próxima à quebra da plataforma (Figuras 12, 13 e 14).

A profundidade da quebra da plataforma variou ao longo das seções, com valores de 150 a 160 metros. Essa variação é resultado dos processos erosivos e morfológicos ao longo da área. Nas figuras 12, 13, 14, 15, 16 e 17 observam-se as localizações das feições morfológicas citadas anteriormente e a localização da quebra da Plataforma.

Tabela 2. Descrição das seções batimétricas na Plataforma Continental Externa.

\begin{tabular}{|c|c|c|c|}
\hline Seção & $\begin{array}{c}\text { Comprimento } \\
\text { Sondado }(\mathbf{K m})\end{array}$ & Gradiente & $\begin{array}{c}\text { Profundidade da quebra } \\
\text { da Plataforma (m) }\end{array}$ \\
\hline 1 & 36 & 0.04 & 150 \\
\hline 2 & 24 & 0.09 & 160 \\
\hline 3 & 23.5 & 0.13 & 160 \\
\hline 4 & 24 & 0.08 & 156 \\
\hline 5 & 36 & 0.08 & 160 \\
\hline 6 & 27 & 0.04 & 160 \\
\hline 7 & - & - & - \\
\hline 8 & 28 & 0.05 & 160 \\
\hline 9 & 36 & 0.02 & 155 \\
\hline 10 & 28 & 0.03 & 150 \\
\hline 11 & - & - & - \\
\hline
\end{tabular}




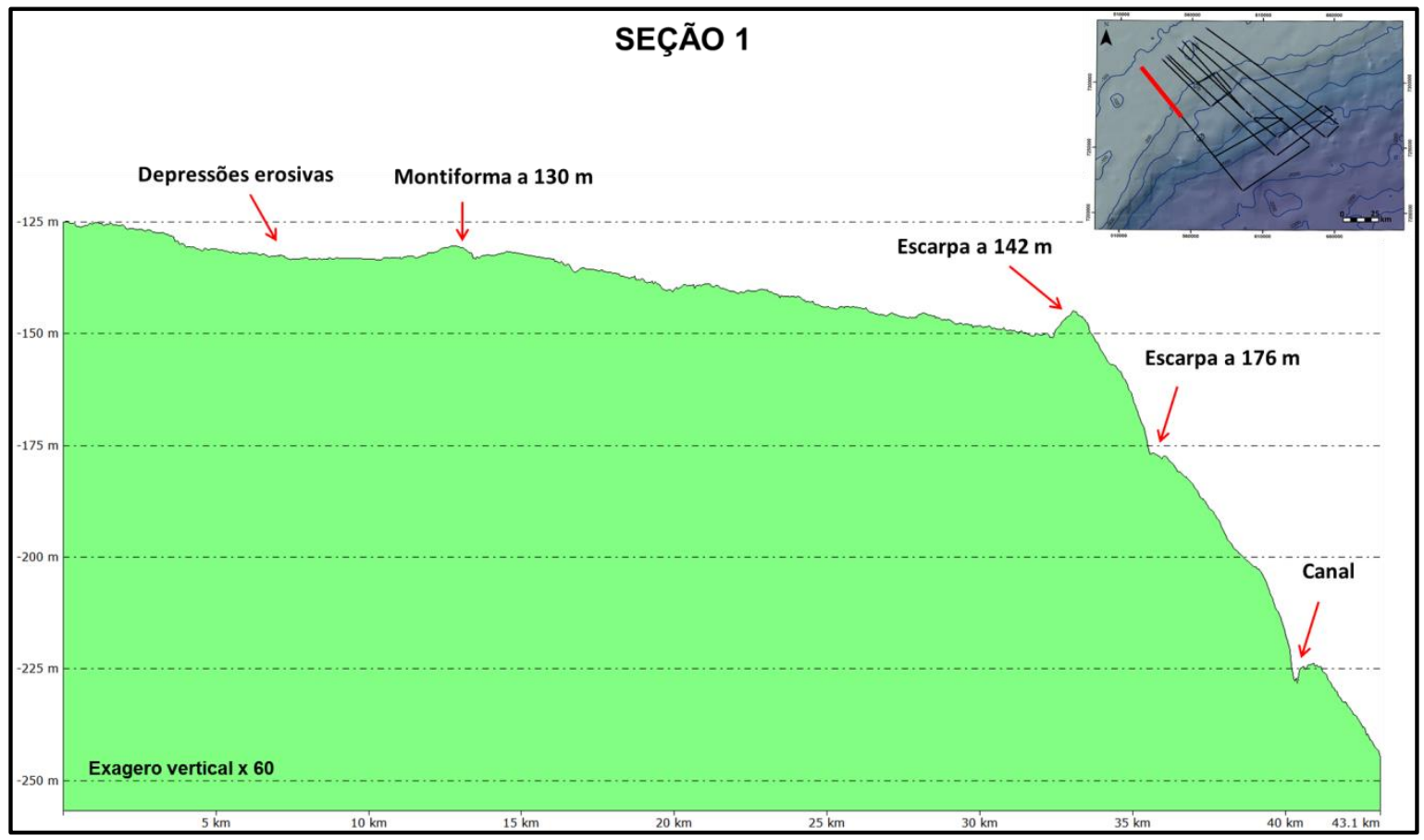

Figura 12. Perfil batimétrico da Plataforma Externa e Talude Superior da Seção 1.

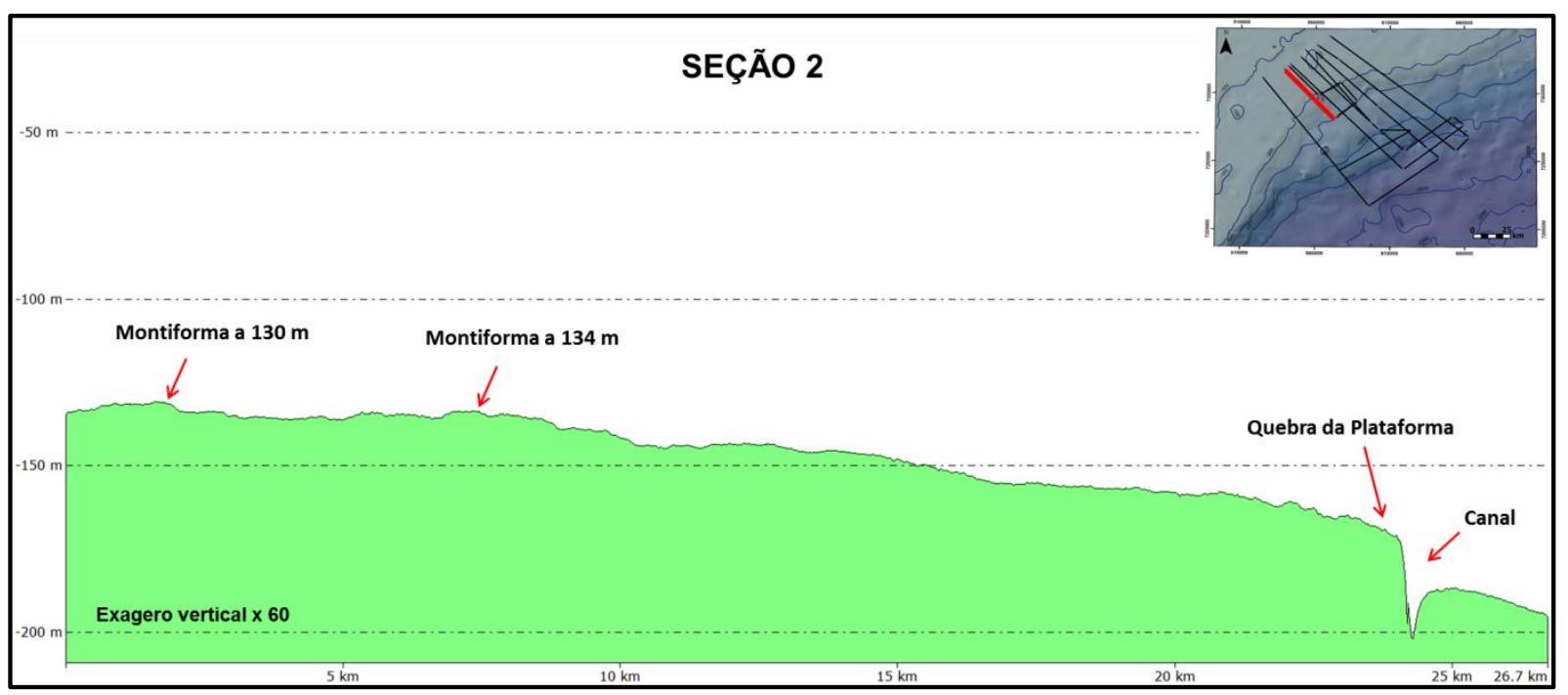

Figura 13. Perfil batimétrico da Plataforma Externa da Seção 2. 


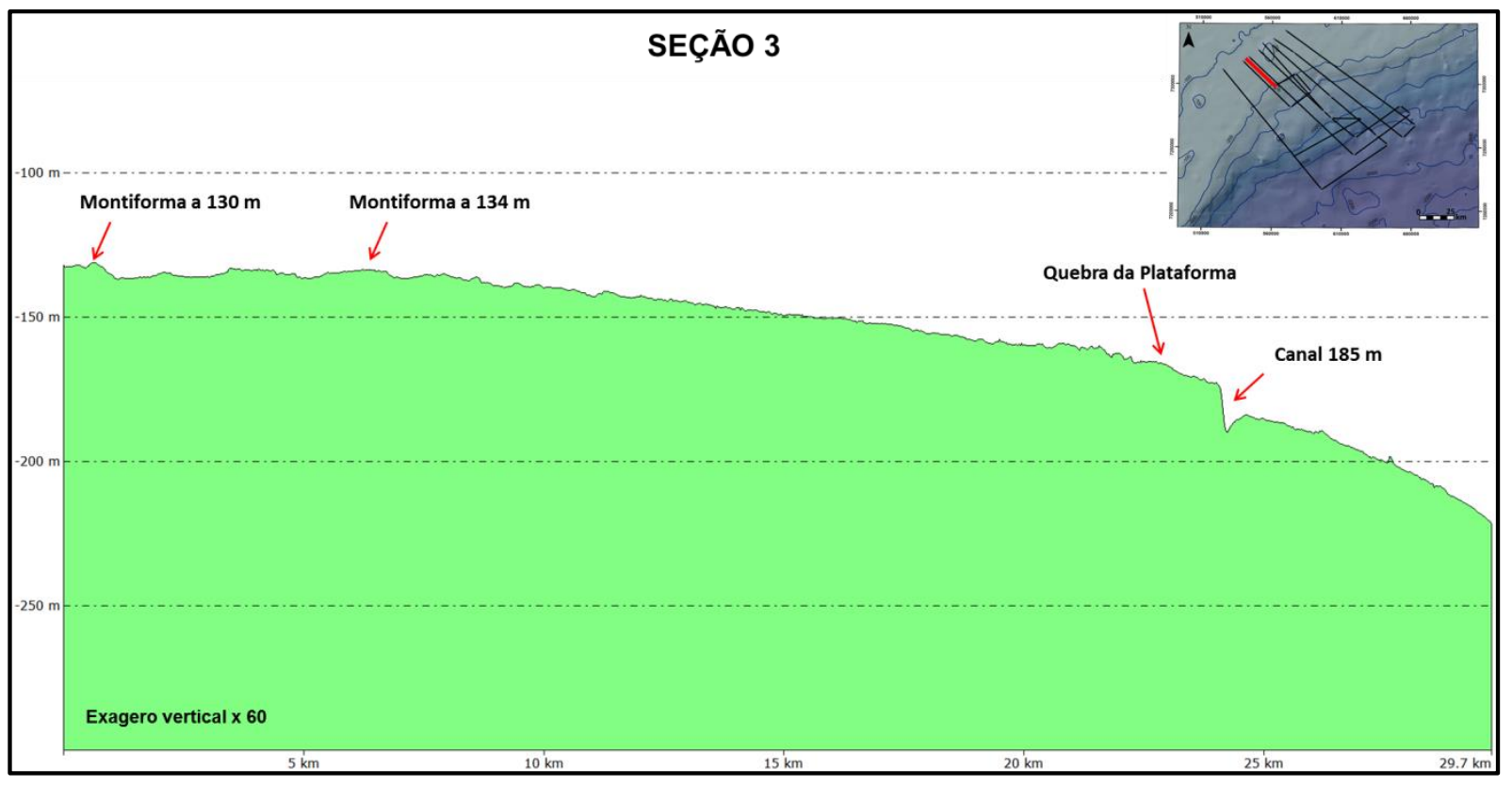

Figura 14. Perfil batimétrico da Plataforma Externa e da quebra da Plataforma da Seção 3.

NW

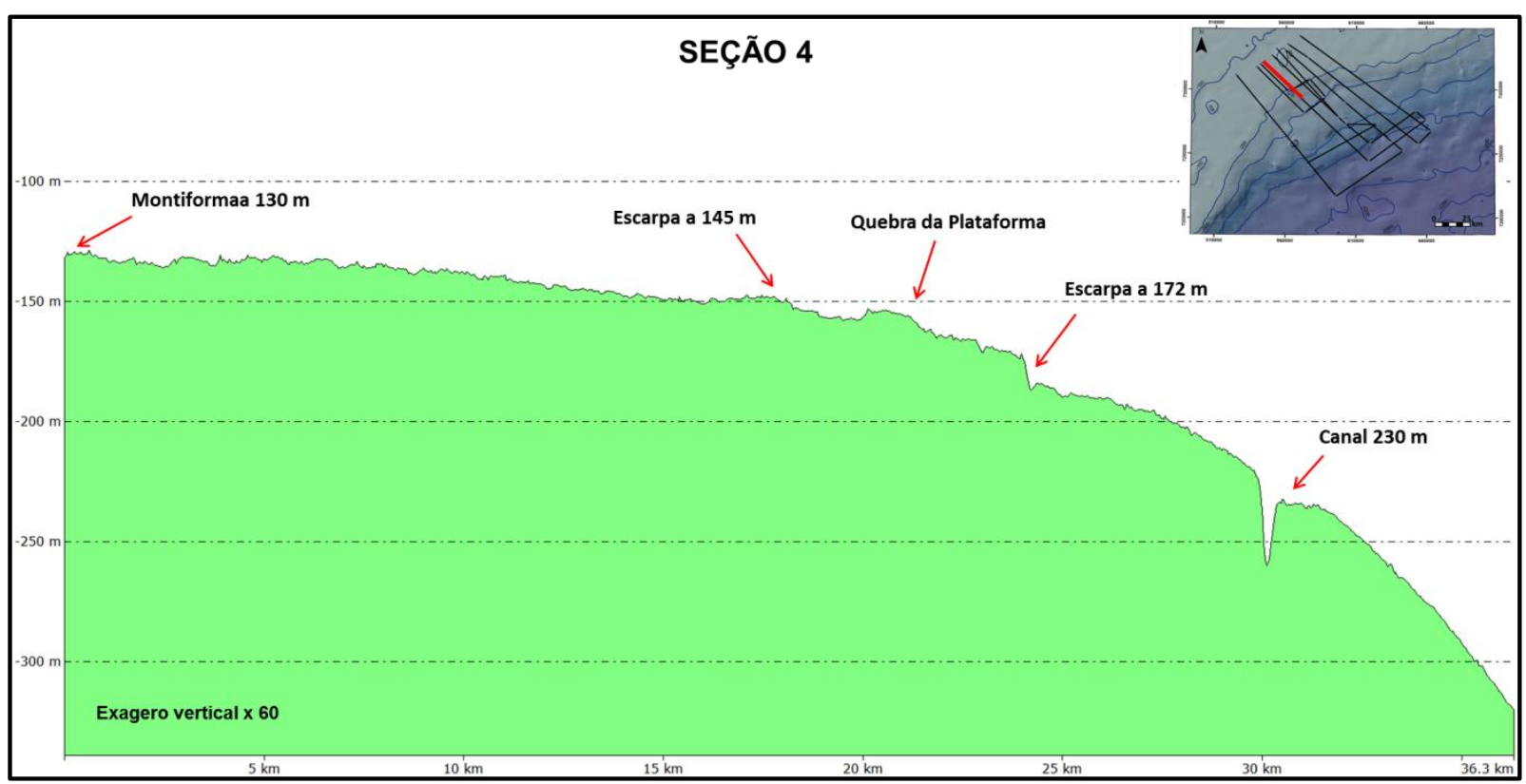

Figura 15. Perfil batimétrico da Plataforma Externa e da quebra da Plataforma da Seção 4. 


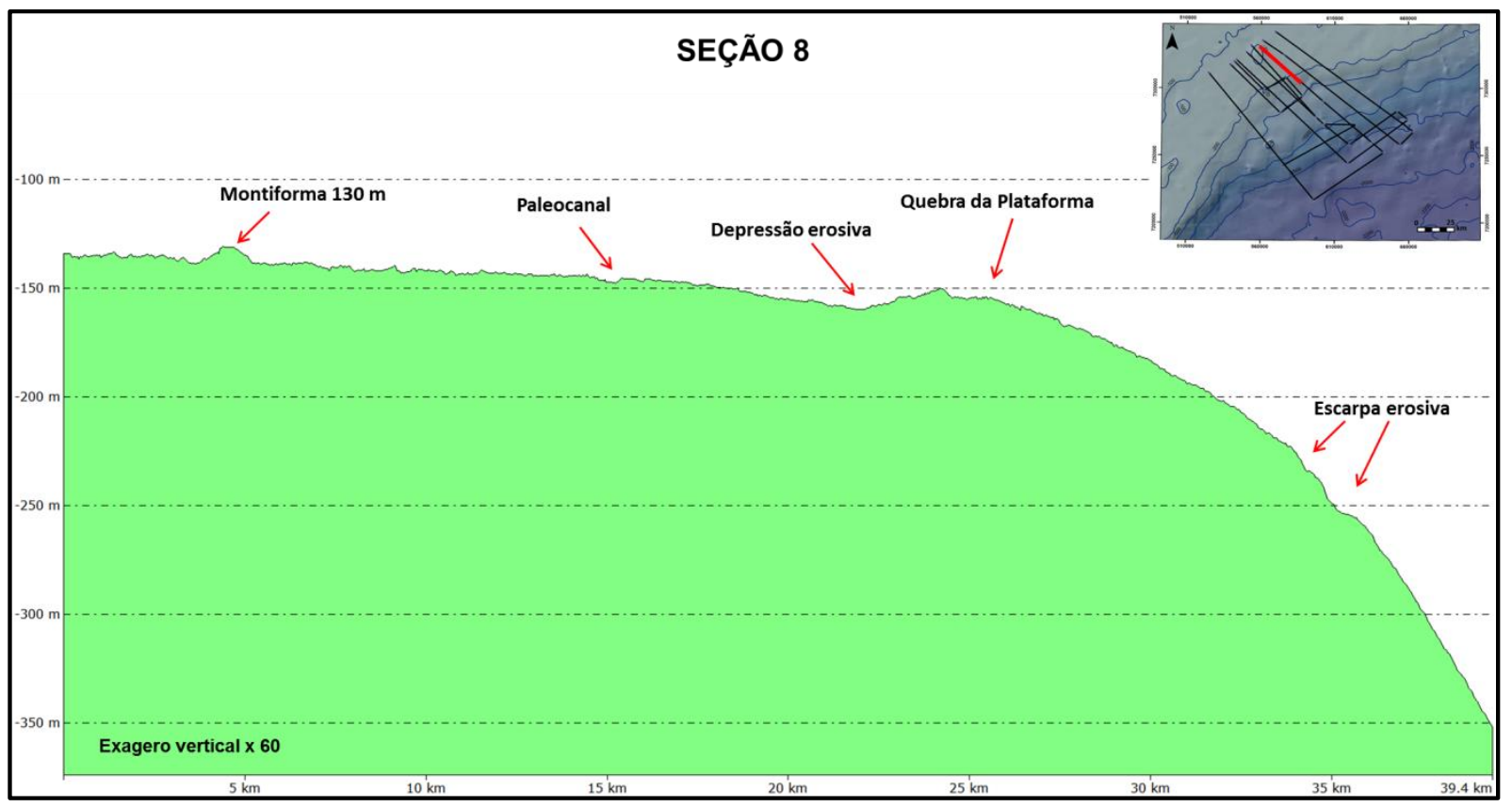

Figura 16. Perfil batimétrico da Plataforma Externa e inicio do Talude Superior da Seção 8.



Figura 17. Perfil batimétrico da Plataforma Externa e Talude Superior da Seção 10. 


\subsubsection{SÍSMICA DA PLATAFORMA EXTERNA}

Ao analisar os registros sísmicos da Plataforma Externa verifica-se que as seções possuem o mesmo padrão sedimentar. De uma forma geral os registros sísmicos na Plataforma externa apresentam um padrão de baixa penetração do sinal acústico no sedimento, com alta refletividade de fundo.

No setor mais interno da Plataforma Externa os registros sísmicos possuem penetração de mais de 25 metros de espessura. Observa-se que os sedimentos possuem padrão progradante. Posteriormente esse pacote é recoberto por um pacote de alta refletividade e homogêneo. Neste pacote estão inseridos montiformas sempre visualizados na isóbata de 130 e 134 metros de profundidade, conforme ilustrado nas Figuras 20, 21 e 22. Neste setor interno da plataforma são identificadas feições erosivas, com truncamento de refletores, gerando uma superfície erosiva (Figuras 19 e 20). Na seção 5 destaca-se a visualização de paleocanais preenchidos, entre as duas escarpas erosivas, sendo esses recobertos por dois pacotes sedimentares distintos (Figura 22).

Após as feições das montiforma, normalmente a 130 metros, nota-se uma mudança no padrão de refletividade. A penetração do sinal quase não ocorre, indicando que o sedimento com alta refletividade, impede a penetração do sinal. Esse padrão mantém-se até a região da quebra da plataforma, conforme ilustrado nas figuras 18, 25 e 26 .

A região da quebra da Plataforma é marcada por uma superfície extremamente irregular, com sinal acústico praticamente sem penetração. Logo 
após a quebra começa a ocorrer a penetração do sinal, sendo possível verificar alguns poucos refletores seguindo o padrão plano-paralelo. Imediatamente abaixo da quebra da plataforma observa-se um canal, que em algumas áreas se expressa como uma escarpa erosiva, próximo à isóbata dos 160 metros. A partir desta escarpa há uma mudança total no padrão de sedimentação, apresentando refletores paralelos bem marcados conforme ilustrado na figura 18.

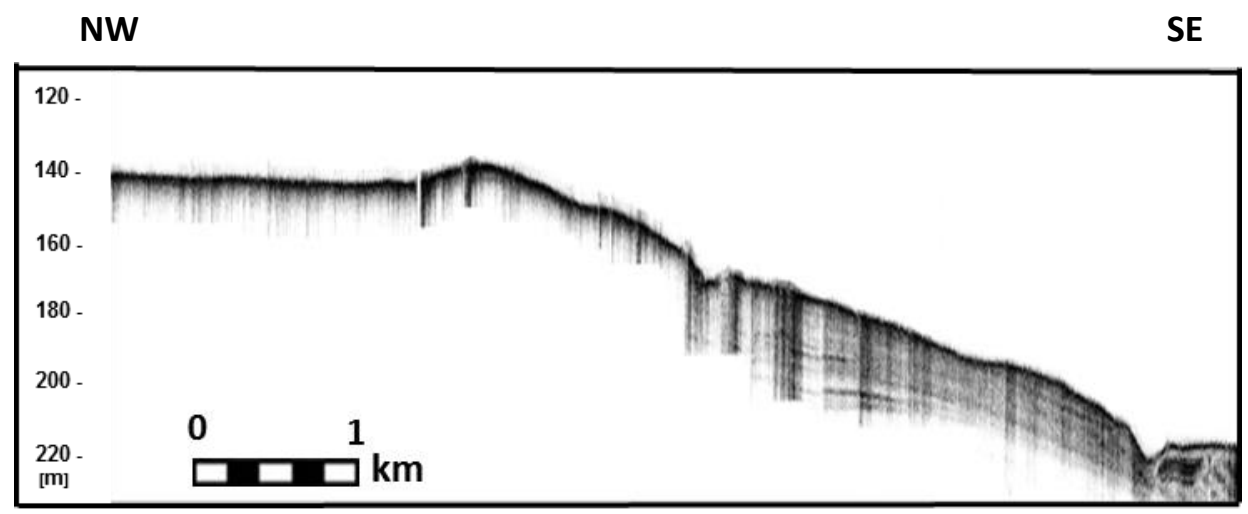

Figura 18. Perfil sísmico da Seção 1, destacando a quebra da plataforma e início do Talude superior. 
90-

100.

110 -

$110-$

130 -

140 -

150 -

160 -

[m]

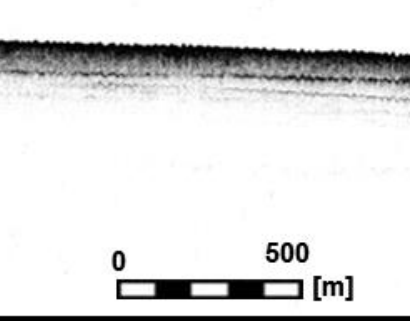

Depressão erosiva

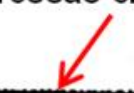

Figura 19. Perfil sísmico da Seção 2 do setor interno da Plataforma Externa.

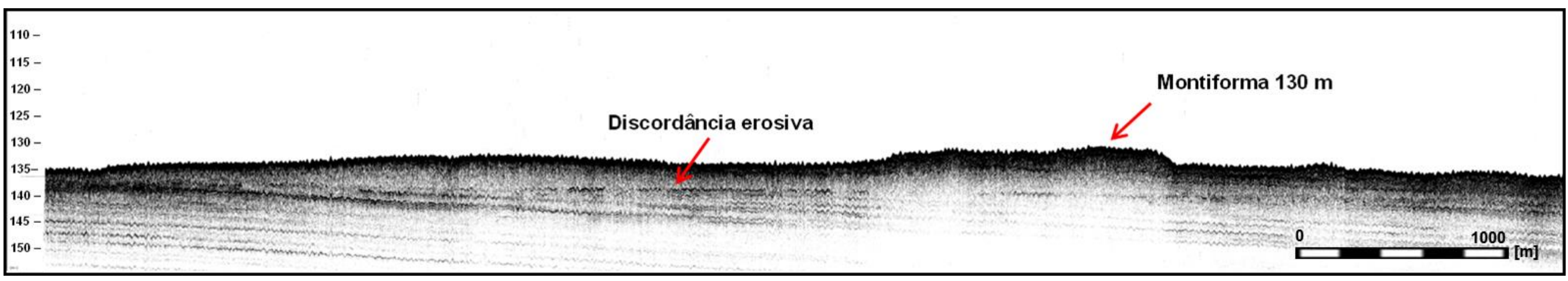

Figura 20. Perfil sísmico da Seção 2 da Plataforma Externa, dando destaque a escarpas e discordância erosiva. 


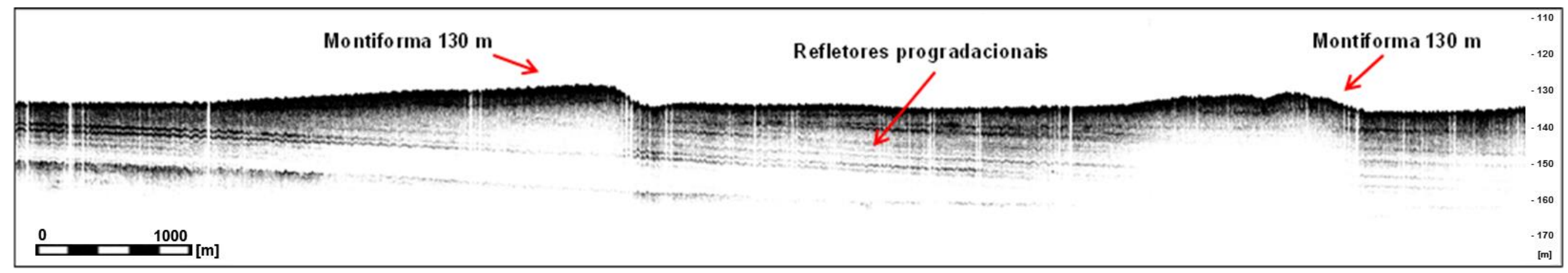

Figura 21. Perfil sísmico da Plataforma da Seção 3. Destaque para refletores progradacionais e montiformas na superfície.

NW

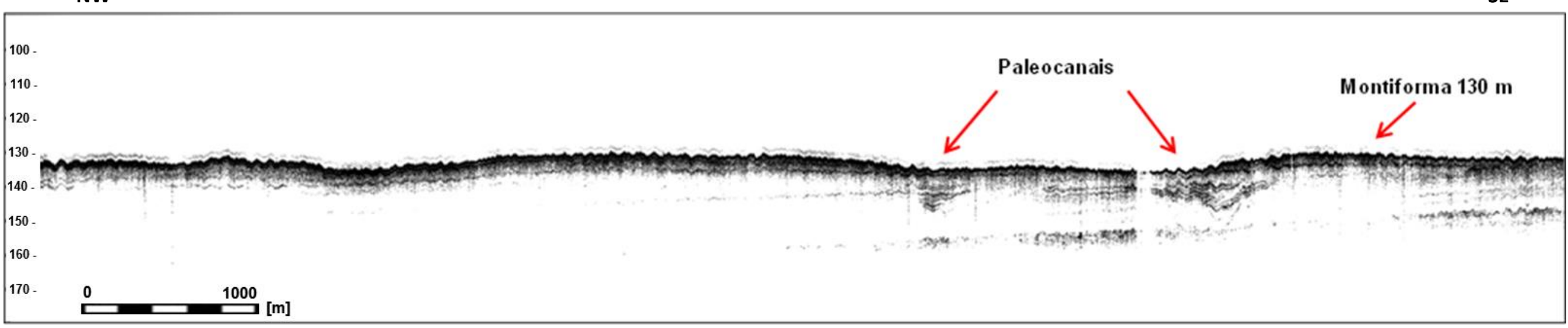

Figura 22. Perfil sísmico da Plataforma da Seção 5. Destaque para paleocanais preenchidos sendo recoberta pela montiformas. 


\subsection{TALUDE SUPERIOR}

O Talude Superior inicia-se após a quebra da Plataforma e se estende até a isóbata de 600 metros. O comprimento médio do talude superior na área de estudo é de aproximadamente $36 \mathrm{~km}$. Ao longo do talude observam-se alterações no seu grau de inclinação. Esse comportamento ocorreu em todas as seções sondadas. Inicialmente sua inclinação média é de aproximadamente $0.55^{\circ}$ e, após a isóbata 250 metros, há uma tendência ao aumento de inclinação. As seções localizadas mais a sudoeste apresentam inclinações próximas a $1.2^{\circ}$ e as seções a nordeste inclinações de $1.5^{\circ}$. Posteriormente, próximo à isóbata de 420 metros a inclinação tende a diminuir para $0.7^{\circ}$ (Figuras 23 e 24).

Na parte superior do talude observa-se ao longo das seções a formação de dois canais e/ou escarpas erosivas. Essas escarpas ou canais tendem a se acentuar próximo das seções a sudoeste. Destaca-se a formação de uma escarpa erosiva iniciada na Seção 6 e visualizada nas demais seções para sudoeste (Seções 1 a 6). Esta escarpa inicia-se a 165 metros, migrando lateralmente e se acanalando, formando um canal na isóbata de 175 metros. Nas proximidades da seção 2, o canal obtém sua maior dimensão, com 500 metros de largura e 14 metros de profundidade. Este canal tende a diminuir sua dimensão novamente em direção à Seção 1 (Figuras 12, 13, 14 e 15).

Observa-se a formação de outro canal, também paralelo ao talude, em profundidade maior. Este canal também pode ser visualizado em quase todas as seções. Diferentemente do canal mais raso, este não apresenta expressão marcada em todos os perfis. O canal inicia-se junto à isóbata de 250 metros 
profundamente, como uma feição de terraço e atinge uma profundidade de 280 metros nas proximidades da seção S7. A partir deste ponto ele torna-se novamente mais raso até atingir a isóbata de 225 metros na seção S1. Neste canal é possível verificar que há migração na profundidade, logo denotando sua variação no tempo e espaço. Na Seção S4 é possível visualizar a migração do canal ao longo do talude, observa-se que o canal atual corta um antigo paleocanal da região, conforme ilustrado nas Figuras 15 e 23.

Abaixo da isóbata dos 300 metros até os 600 metros não há variações morfológicas na superfície no talude superior que possuam expressão.

NW SE

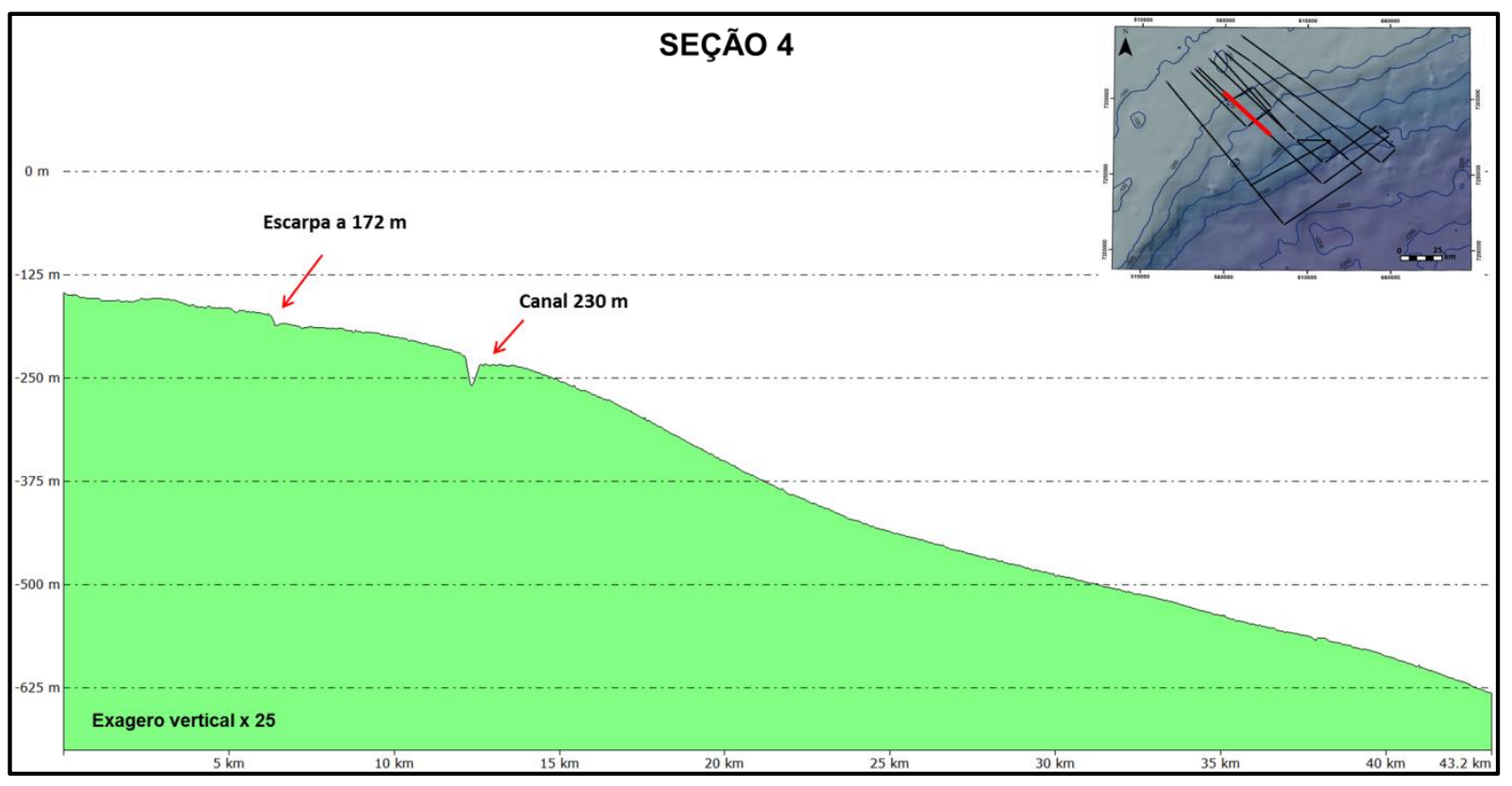

Figura 23. Perfil batimétrico do Talude Superior da Seção 4. 


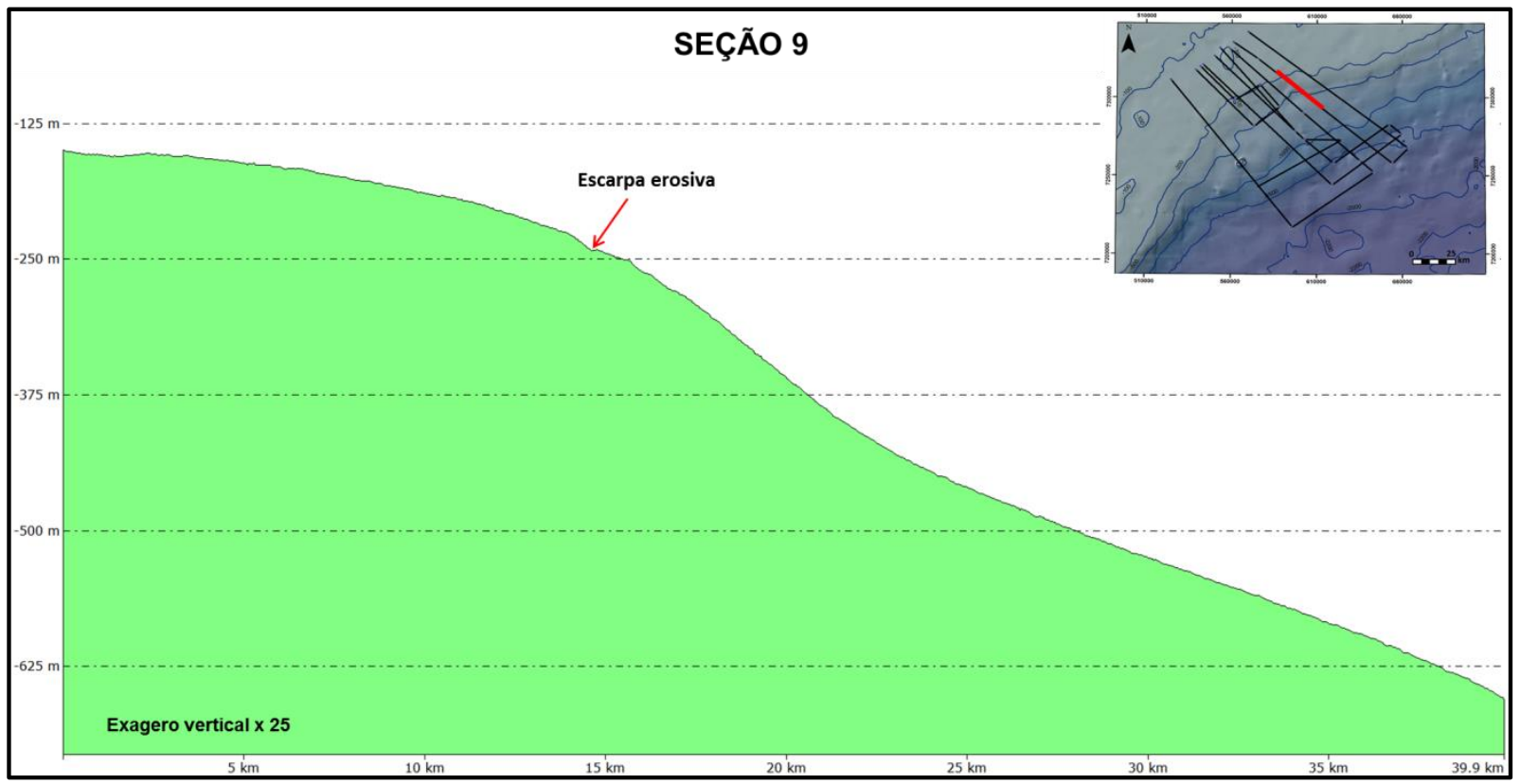

Figura 24. Perfil batimétrico do Talude Superior da Seção 9.

\subsubsection{SÍSMICA TALUDE SUPERIOR}

Após a quebra da plataforma, a superfície do fundo ainda apresenta padrão irregular e o pacote sedimentar superficial inibe a penetração do sinal. Esse padrão muda drasticamente após a presença da escarpa / canal erosivo próximo das isóbatas de 160 e 170 metros, conforme ilustrado nas Figuras 18, 25 e 26. Nas figuras é possível observar que antes do canal não há quase penetração do sinal e logo após há uma mudança total no padrão de sedimentação, com refletores paralelos bem marcados. Esses refletores passam a ter um padrão progradante e com alta intensidade de reflexão, até próximo a isóbata dos 350 metros, onde há nova mudança no padrão sedimentar. Verifica-se que entre 160 até 250 metros há presença de uma superfície erosiva, que erode por completo o inicio dos refletores, evidenciando 
alto processo erosivo na região, conforme llustrado nas Figuras 27, 28, 29 e 30.

Nos registros sísmicos é possível observar a presença de inúmeros paleocanais entre as isóbatas de 225 até 270 metros. Alguns registros, como da Seção 4, visualizam-se três paleocanais, sendo que um deles sofre processo erosivo. Esses paleocanais indicam a migração ao longo do tempo, do atual canal que corta o talude (Figura 28).

Logo após a isóbata dos 280 metros, observa-se que há um padrão de deformação no sedimento podendo indicar um fluxo gravitacional (Figura 30). Após essa zona de deformação encontram-se ondas de sedimento próximo da isóbata dos 350 metros. Há a mudança no padrão sedimentar, pois na interface água/sedimento há refletor com alta refletividade, seguido por um pacote sedimentar homogêneo, com espessura de aproximadamente 7 metros. Logo abaixo se iniciam as ondas de sedimento com espessura de mais de 35 metros, conforme ilustrado nas Figuras 31 e 32.

A partir dos 550 metros de profundidade essas ondas sofrem afinamento e passam a formar refletores plano-paralelos de alta refletividade, que se propagam por toda a região do talude inferior. 


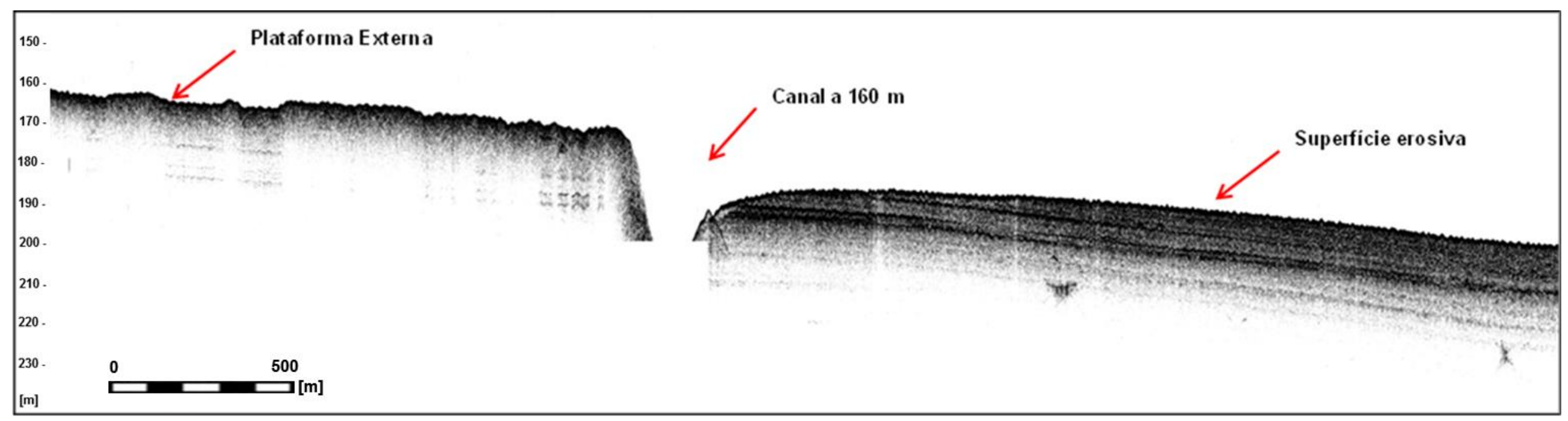

Figura 25. Perfil sísmico da Seção 2 destacando a presença do canal de erosivo e mudança no padrão de reflexão.

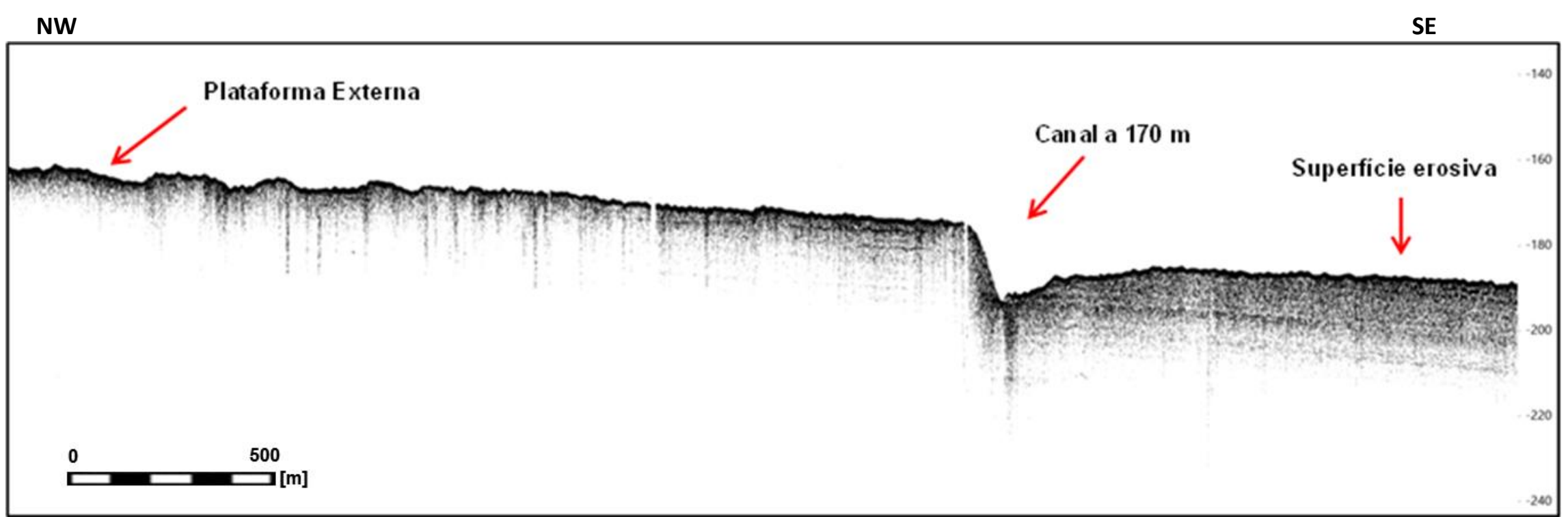

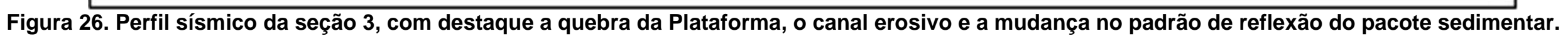




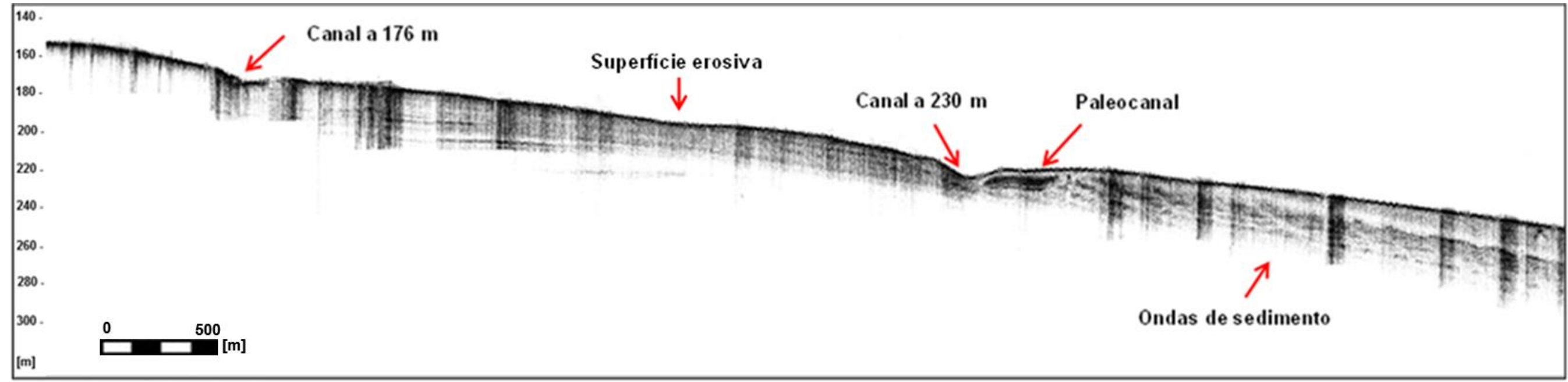

Figura 27. Perfil sísmico do Talude Superior da Seção 1, demonstrando os dois canais, paleocanal e ondas de sedimento.

NW

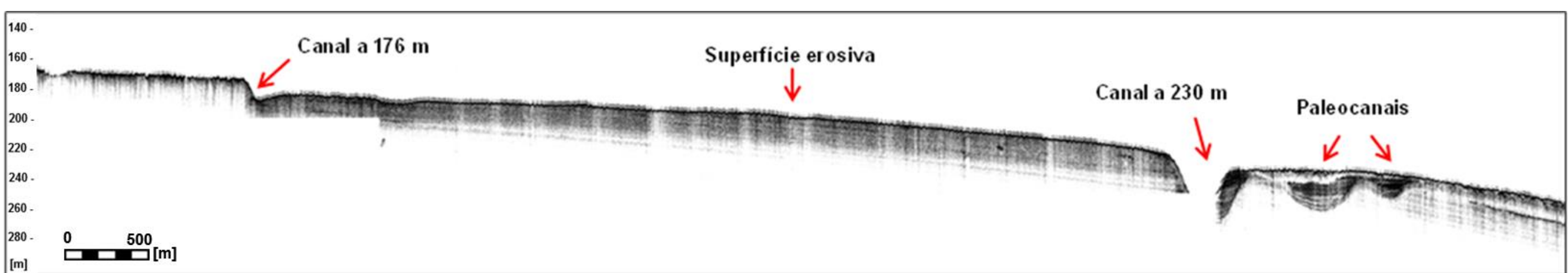

Figura 28. Perfil sísmico do Talude Superior da Seção 4 demonstrando os canais, paleocanais e superfície erosiva. 


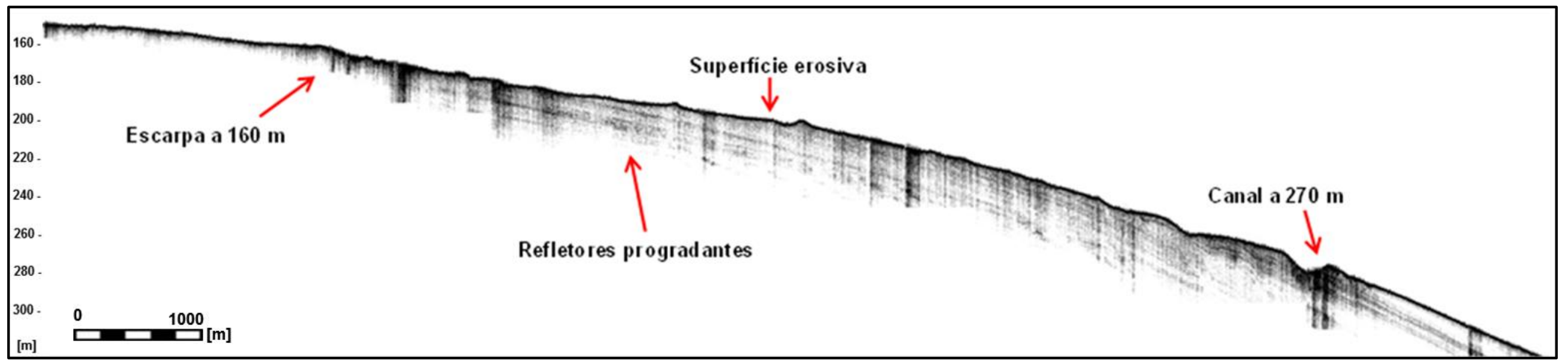

Figura 29. Perfil sísmico da Seção 6 destaque para o canal, escarpa e superfície erosiva.

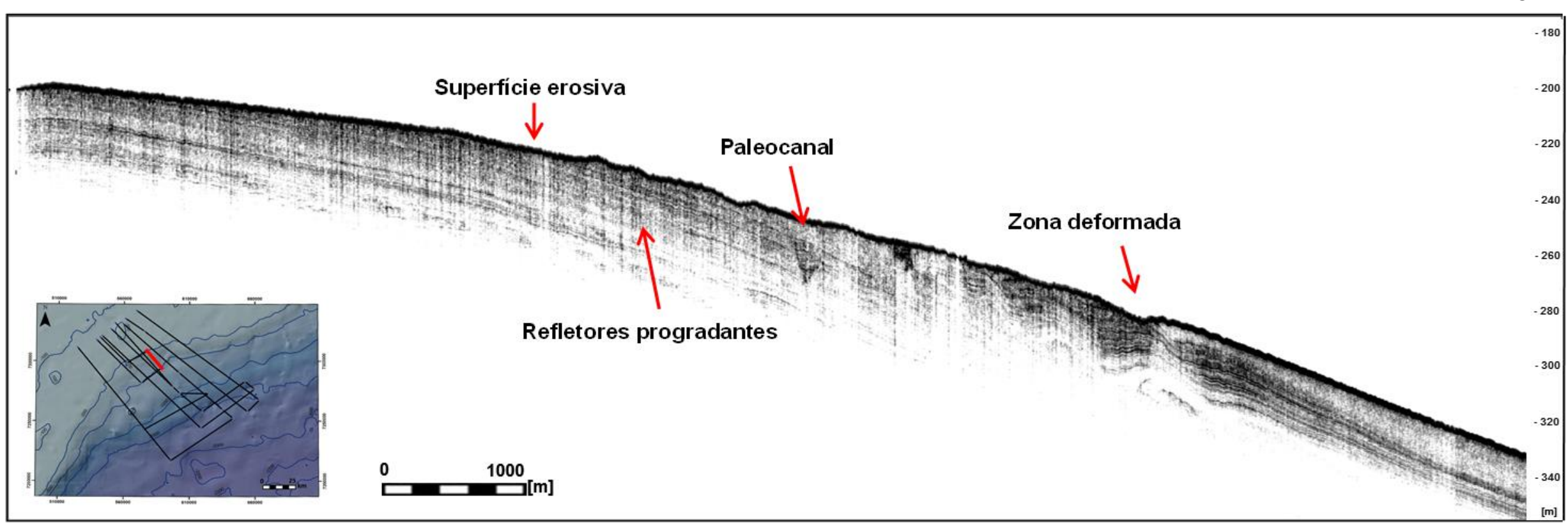

Figura 30. Perfil sísmico da Seção 7 destacando a zona de deformação, paleocanal e superfície erosiva. 
350

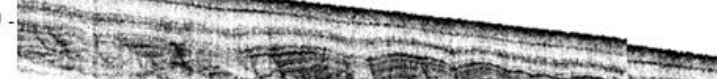

450

500
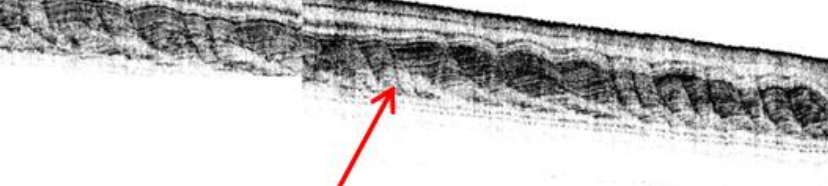

Ondas de Sedimento

550. $\quad 0$

${ }^{0} \quad 1000[\mathrm{~m}]$

Figura 31. Perfil sísmico do Talude Superior da Seção 2 destacando ondas de sedimento na base do registro.

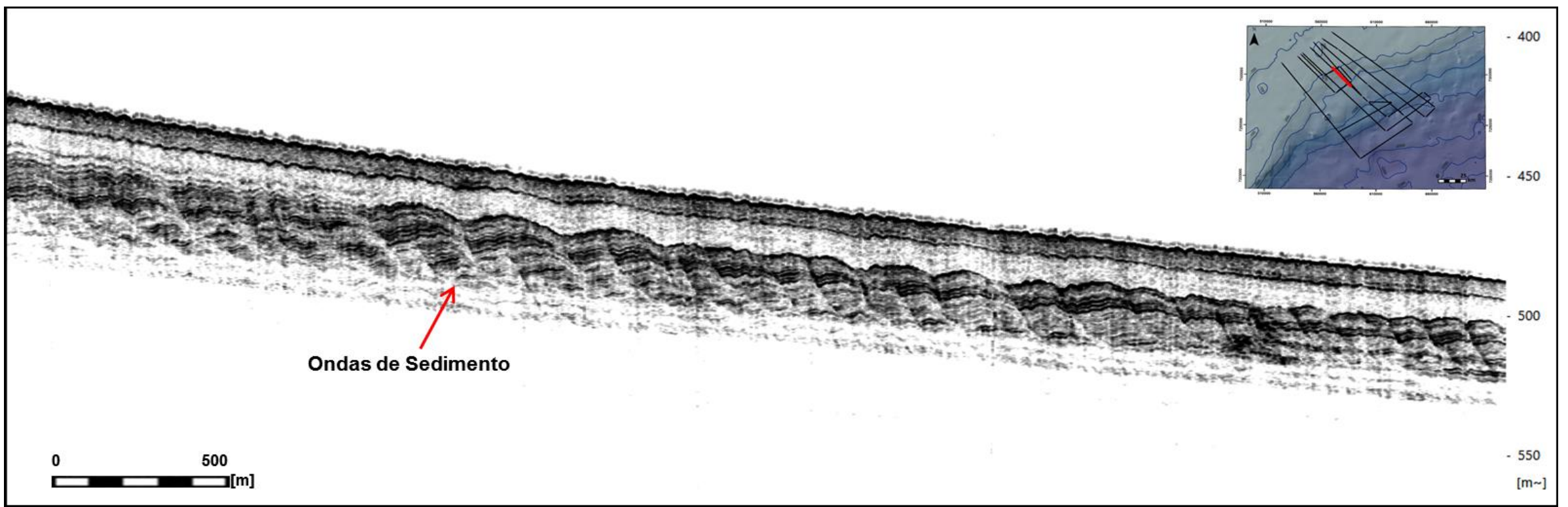

Figura 32. Perfil sísmico do Talude Superior da Seção 5 destacando as ondas de sedimento. 


\subsection{TALUDE INFERIOR}

O Talude inferior inicia-se após a isóbata de 600 metros e se estende até o término das seções. Ao todo foram sondadas onze seções no talude inferior, tanto longitudinalmente, quanto transversalmente. A profundidade máxima registrada foi de 1975 metros, na seção T6. O comprimento máximo das seções sondadas no talude inferior, na área de estudo, foi de aproximadamente $62 \mathrm{~km}$.

Observou-se que há diferenças na inclinação entre as seções perpendiculares. Nota-se que as seções a nordeste (seções 6 a 11) apresentam inclinações menores, próximo a $1.3^{\circ}$. Já as seções a sudoeste (seções 4 e 5) apresentaram inclinações, próximo a 1.55․ A seção 1 é a que apresenta maior grau de inclinação com valor de $2.2^{\circ}$. Com relação ao gradiente ao longo das seções, as inclinações aumentam após a isóbata de 1300 metros, podendo chegar a valores de $3.55^{\circ}$, onde sofrem influência do Canal de Santos na base do talude. Após o Canal de Santos a inclinação diminui para valores de $1^{\circ}$, mas de difícil visualização, pois o fundo apresenta muita irregularidade.

No talude inferior, verifica-se que as feições morfológicas visualizadas ao longo das seções, apresentam distribuição lateralmente com o mesmo padrão. Verifica-se a ocorrência na faixa de 600 a 840 metros de inúmeros pockmarks. Já nas proximidades das isóbatas de 1200 e 1300 metros, visualiza-se a presença de canais contorníticos (Figuras 33, 34, 35 e 36). 
Na base do talude visualiza-se o Canal de Santos seguindo paralelo às isóbatas. Mais a nordeste o Canal de Santos está localizado próximo à isóbata de 1550 metros e possui largura na ordem de $3.5 \mathrm{~km}$. Já no setor a sudoeste o canal está mais fundo, junto da isóbata de 1760 metros. A profundidade interna do Canal de Santos é de aproximadamente 100 metros mas, próximo da Seção 8, sua largura diminui para $1.4 \mathrm{~km}$ e atinge 170 metros de profundidade. $\mathrm{Na}$ região da base do talude inferior, após o Canal de Santos, verifica-se a formação de outros canais contorníticos, onde se destacam três feições. Nas figuras 33 a 36 visualizam-se algumas seções perpendiculares ao talude inferior, identificando as principais feições morfológicas.

Com relação às seções transversais, destacam-se a seção T3, T4, T5 e T6. Na seção T3 visualizam-se dois grandes canais. O primeiro mais a sudoeste possui largura inicial de $7.9 \mathrm{~km}$ e mais de 50 metros de profundidade. O segundo canal a nordeste apresenta largura de $7.17 \mathrm{~km}$ e profundidade de 32 metros, conforme ilustrado na figura 37 .

Na seção T4 destacam-se dois canais contorníticos na porção a nordeste. No setor mais a sudoeste visualiza-se um depósito contornítico. $\mathrm{Na}$ região central há presença de feição de dois altos, conforme ilustrado na figura 38. A seção T5 apresenta configuração de relevo completamente irregular, cortada por treze canais, larguras variadas, sempre da ordem de quilômetros, e profundidades de dezenas de metros, conforme ilustrado na figura 39.

A seção T6 apresenta um fundo também irregular, cortado por inúmeros canais, destacando-se três feições. O primeiro canal, mais a sudoeste, possui largura de $3 \mathrm{~km}$ e 15 metros de profundidade. O segundo possui largura de 
$4.14 \mathrm{~km}$ e profundidade máxima de 140 metros, próximo ao flanco direito. $\mathrm{O}$ terceiro canal, no setor mais raso, possui $3.3 \mathrm{~km}$ de largura e 35 metros de profundidade, conforme ilustrado na figura 40.

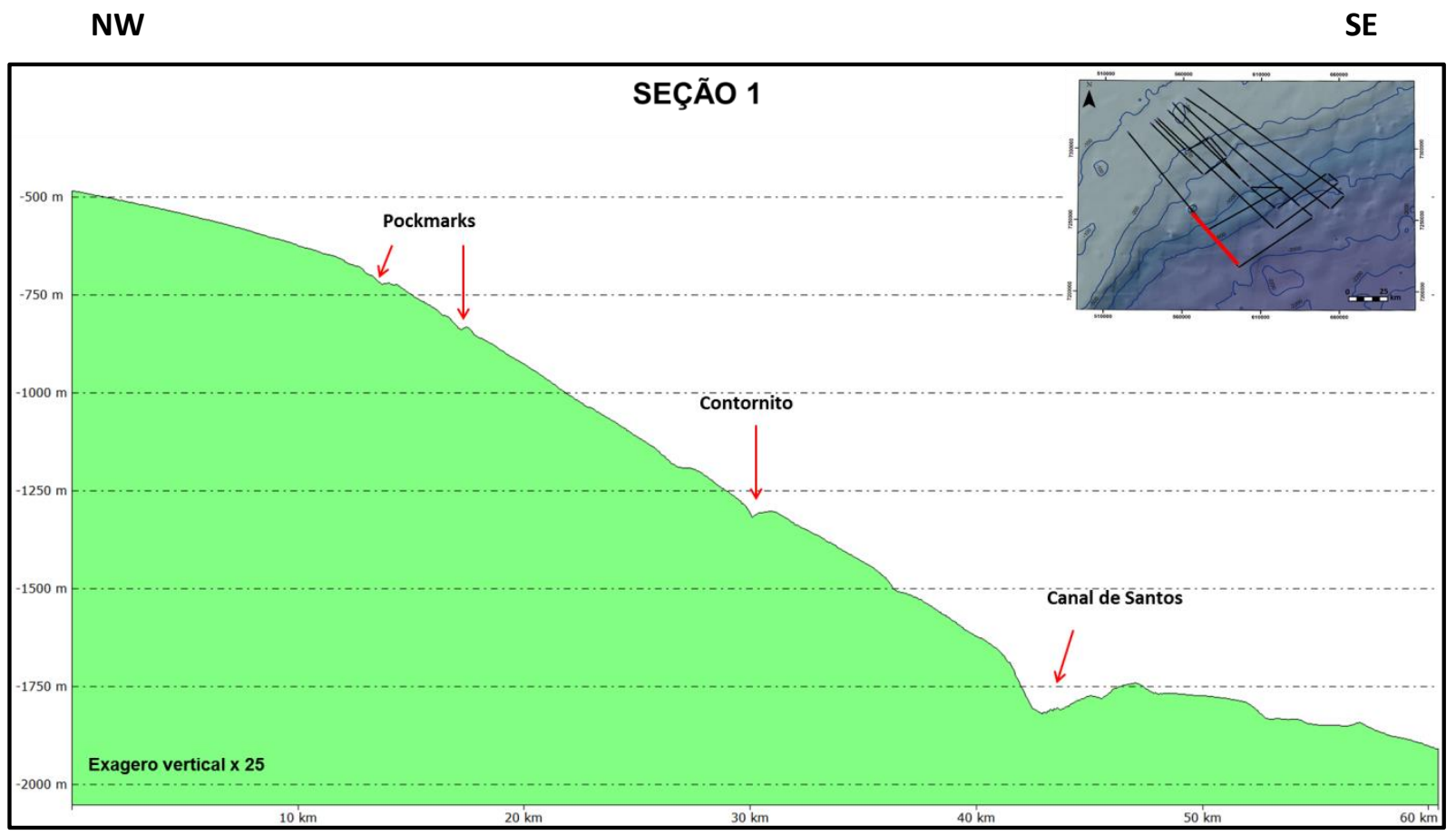

Figura 33. Perfil batimétrico da Seção 1, com destaque para as feições do Talude inferior.

NW SE

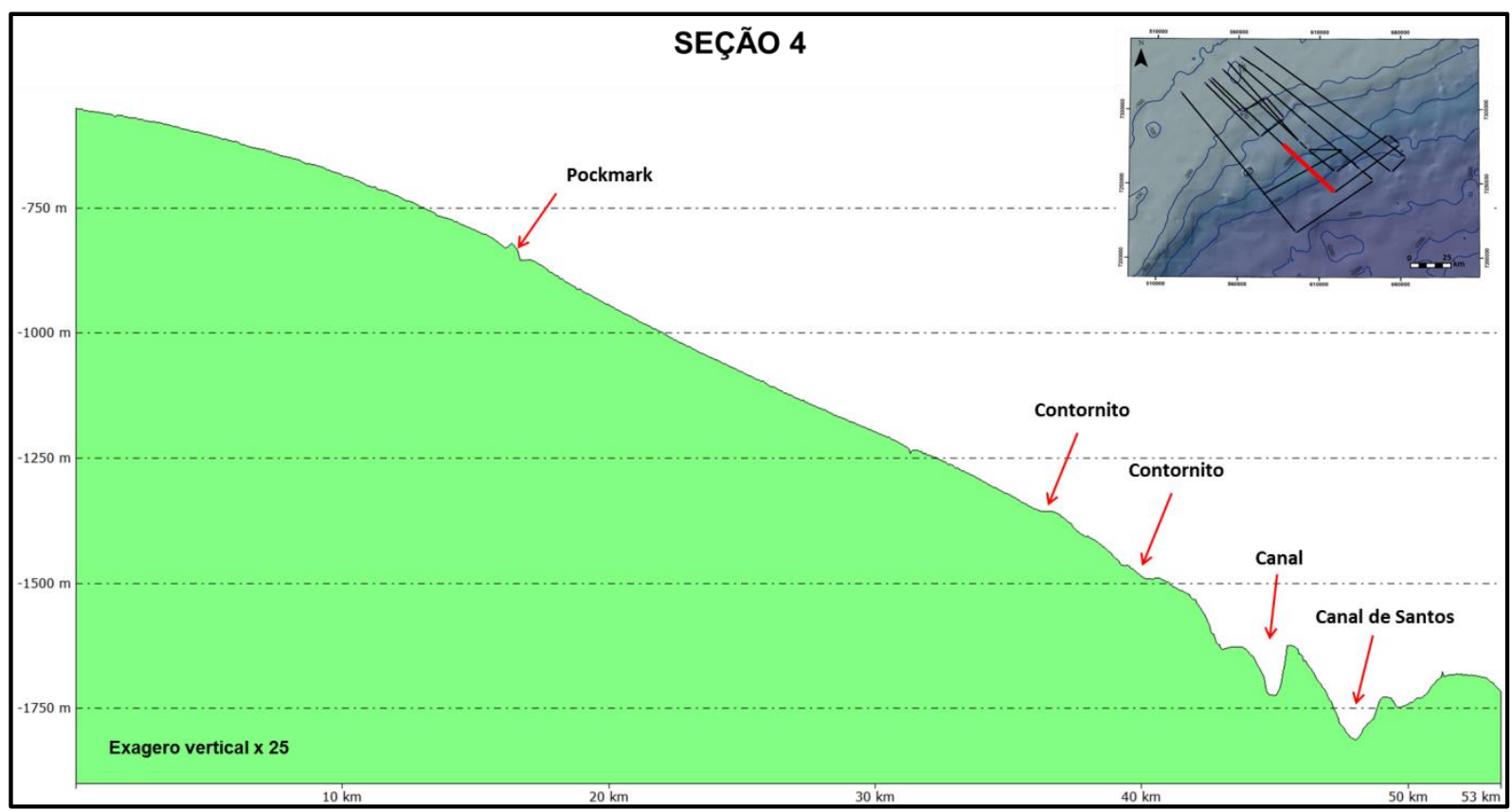

Figura 34. Perfil batimétrico da Seção 4, com destaque para as feições do Talude inferior. 




Figura 35. Perfil batimétrico da Seção 8, com destaque para as feições do Talude inferior.

NW



Figura 36. Perfil batimétrico da Seção 9, com destaque para as feições do Talude inferior. 


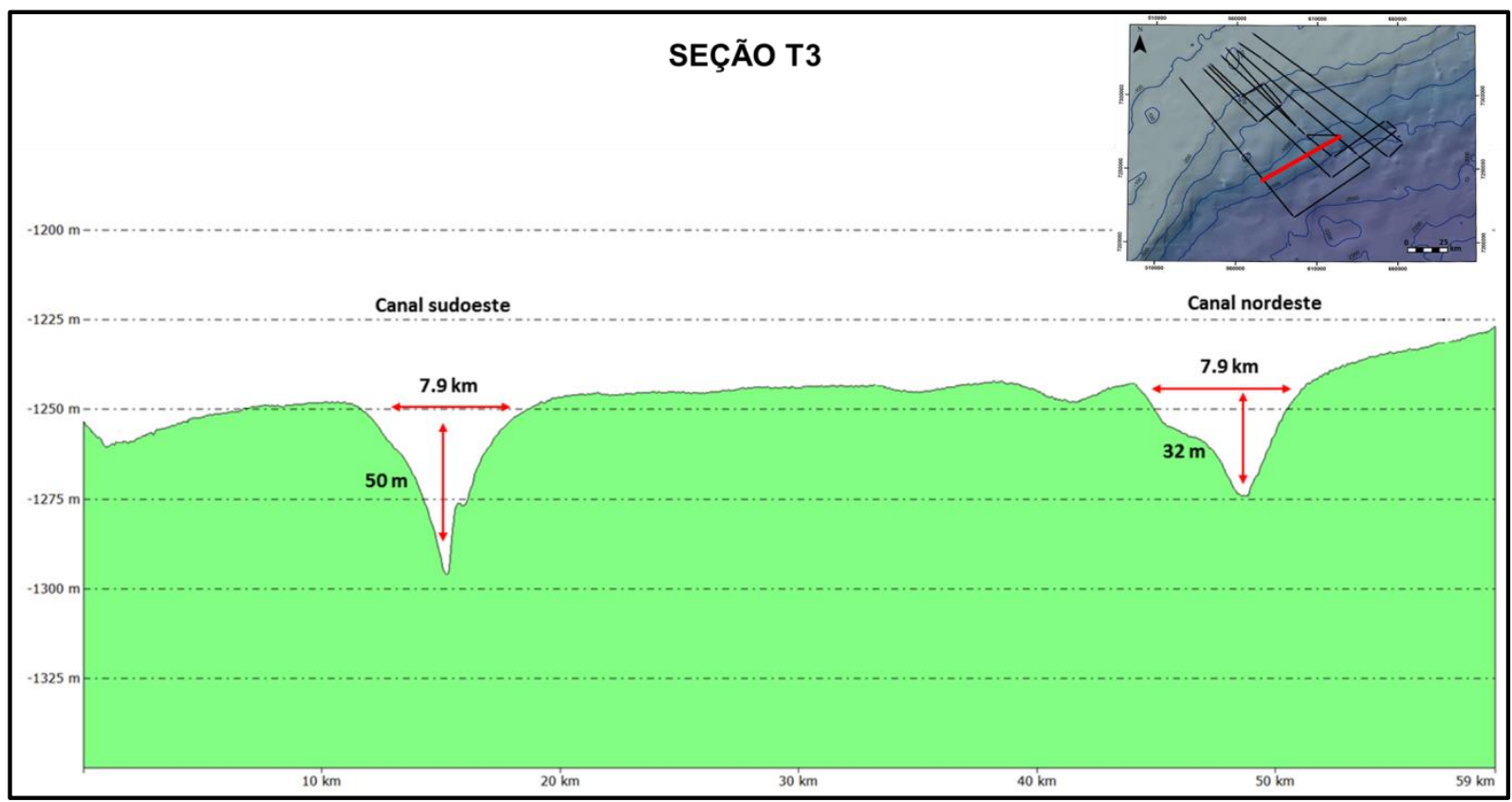

Figura 37. Perfil batimétrico da Seção T3 destacando os dois canais.



Figura 38. Perfil batimétrico da Seção T4 destacando as feições contorníticas e elevações. 


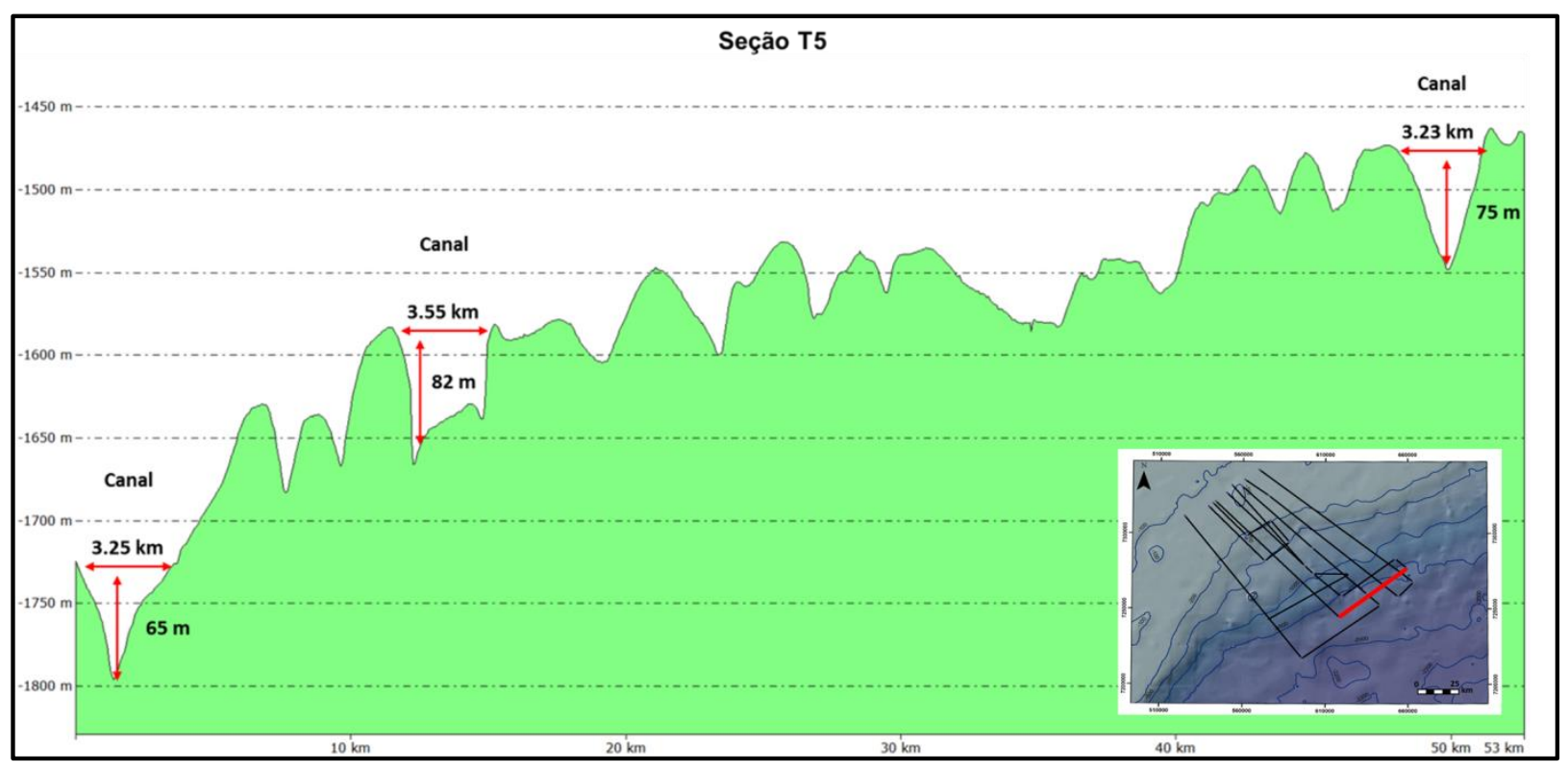

Figura 39. Perfil batimétrico da Seção T5 destacando três canais principais.

SW

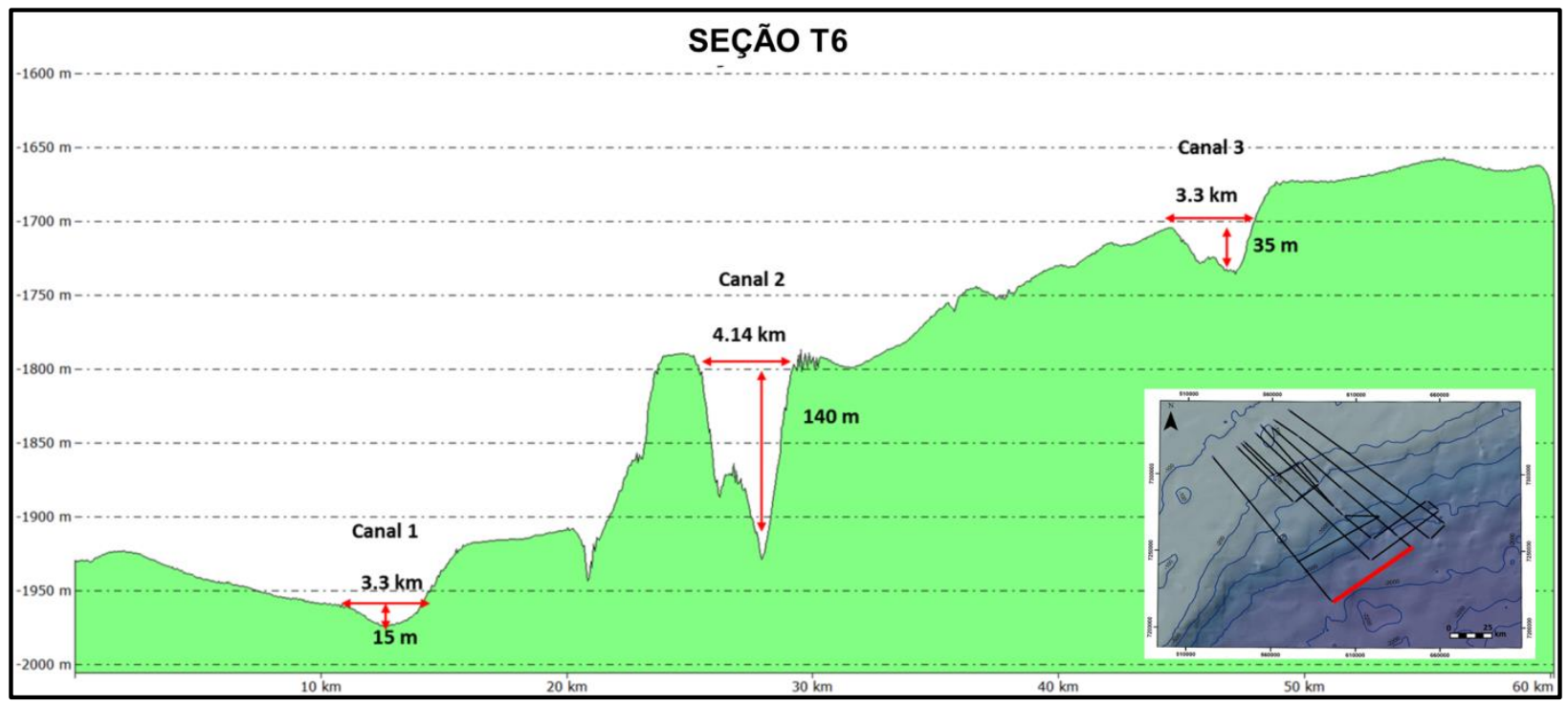

Figura 40. Perfil batimétrico da Seção T6 destacando três canais principais. 


\subsubsection{SÍSMICA DO TALUDE INFERIOR}

Ao longo do Talude Inferior verifica-se que o padrão sedimentar e as feições observadas possuem continuidade lateral, ou seja, também são encontradas nas outras seções sísmicas na área.

Com relação à sedimentação, partir das ondas de sedimentos localizada no Talude Superior, os refletores seguem em conformidade, com padrão planoparalelo ao longo do talude, até as proximidades do Canal de Santos. Verificase que o refletor inicial possui alta refletividade, seguido de um pacote de espessura com mais de 20 metros. Posteriormente, há presença de um refletor bem marcado, com espessura inicial de 6 metros, que se espessa conforme ocorre o aumento da profundidade em direção à base do talude (Figuras 41 e 42).

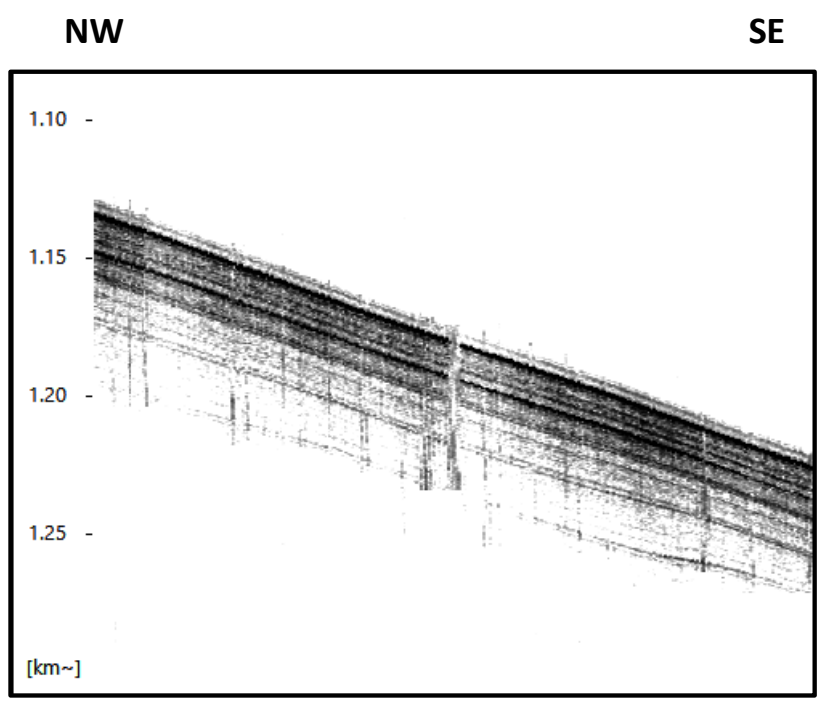

Figura 42. Padrão de reflexão no Talude, seção 1.

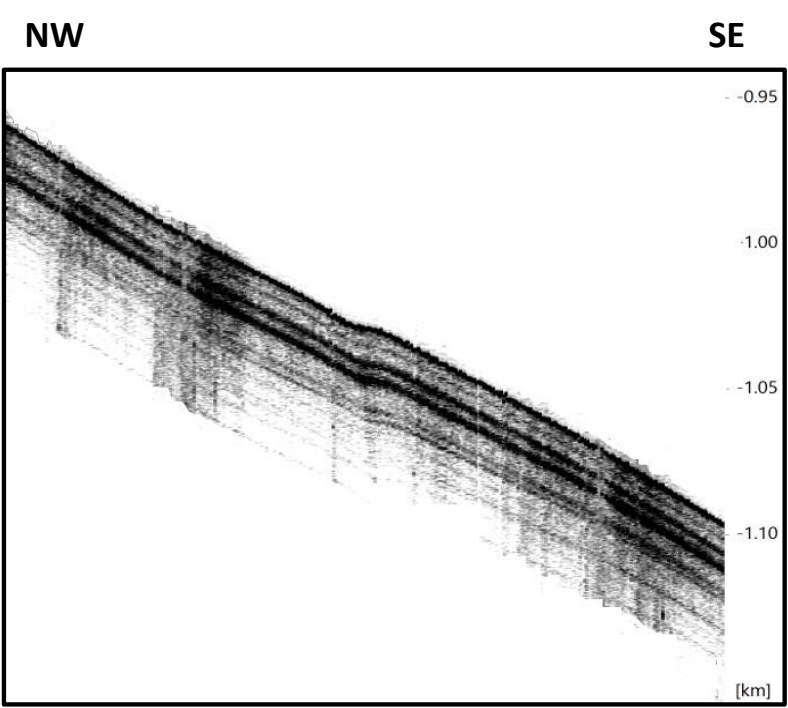

Figura 41. Padrão de reflexão no Talude, seção 4. 
Conforme ocorre o aumento da profundidade, inúmeras feições vão ocorrendo ao longo do Talude, que serão descritas abaixo.

Entre as isóbatas de 580 metros e 830 metros, verifica-se a presença de inúmeros pockmarks na região. Constata-se que a região possui pockmarks ativos, com exsudação de gás e outros inativos. Entre os inativos verifica-se que alguns já sofreram recobrimento por sedimentos. Nas figuras 43,44 e 45 observam-se os registros sísmicos com a presença de pockmarks.

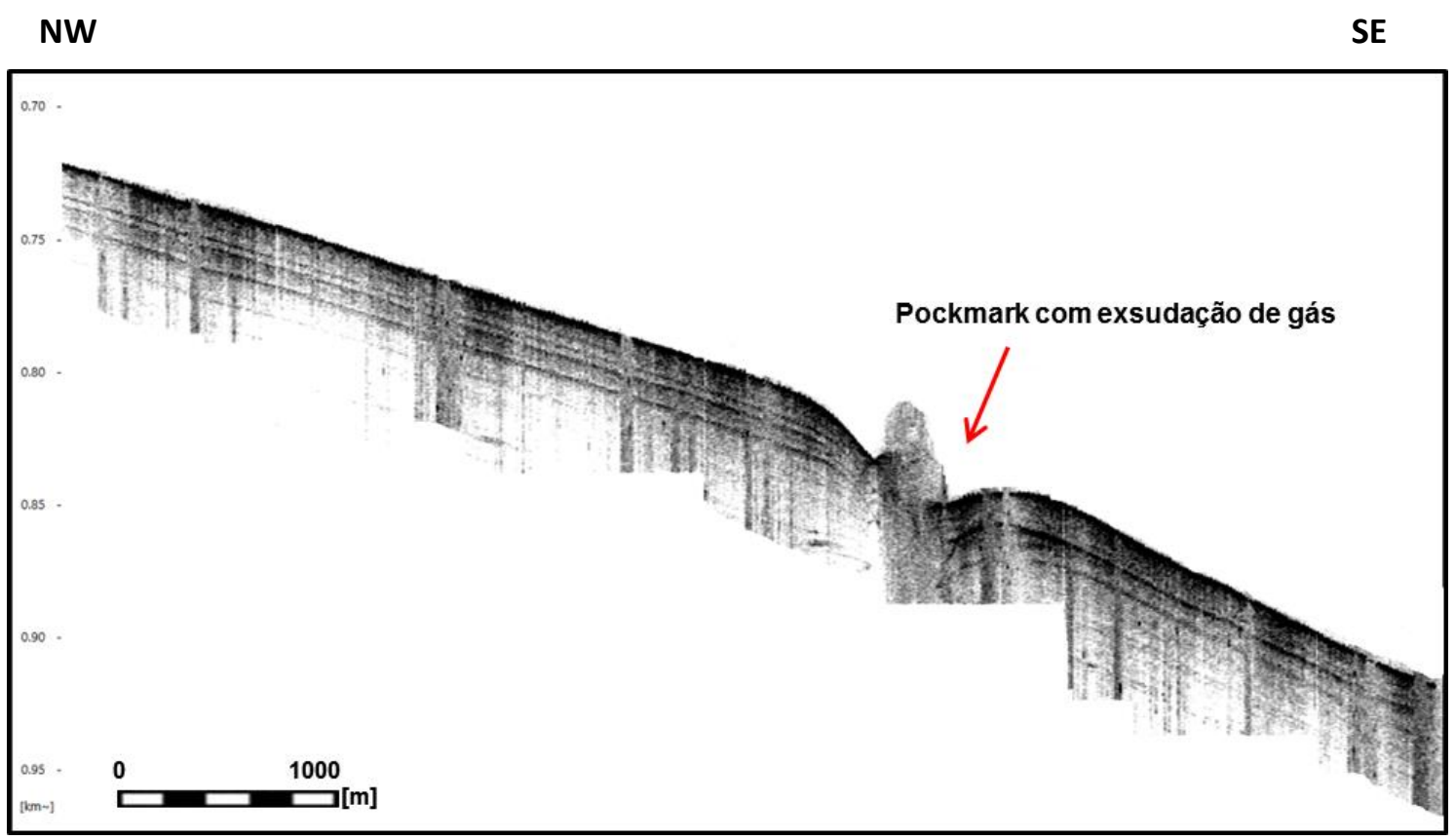

Figura 43. Perfil sísmico do Talude inferior da Seção 6, destacando pockmarks com exsudação de gás e outro inativo e soterrado. 


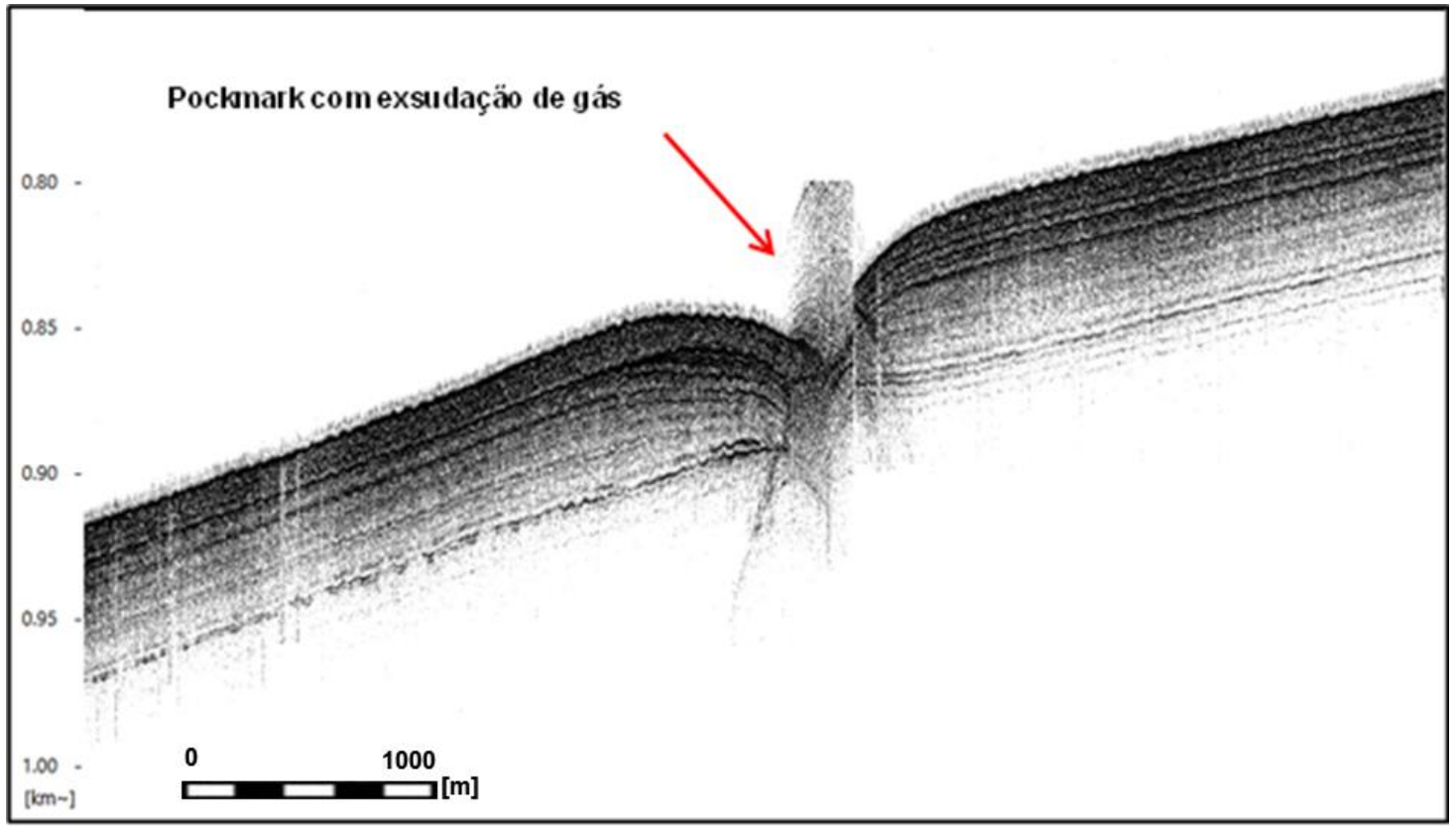

Figura 44. Perfil sísmico do Talude inferior da Seção 3, destacado o pockmark com exsudação de gás.

SE

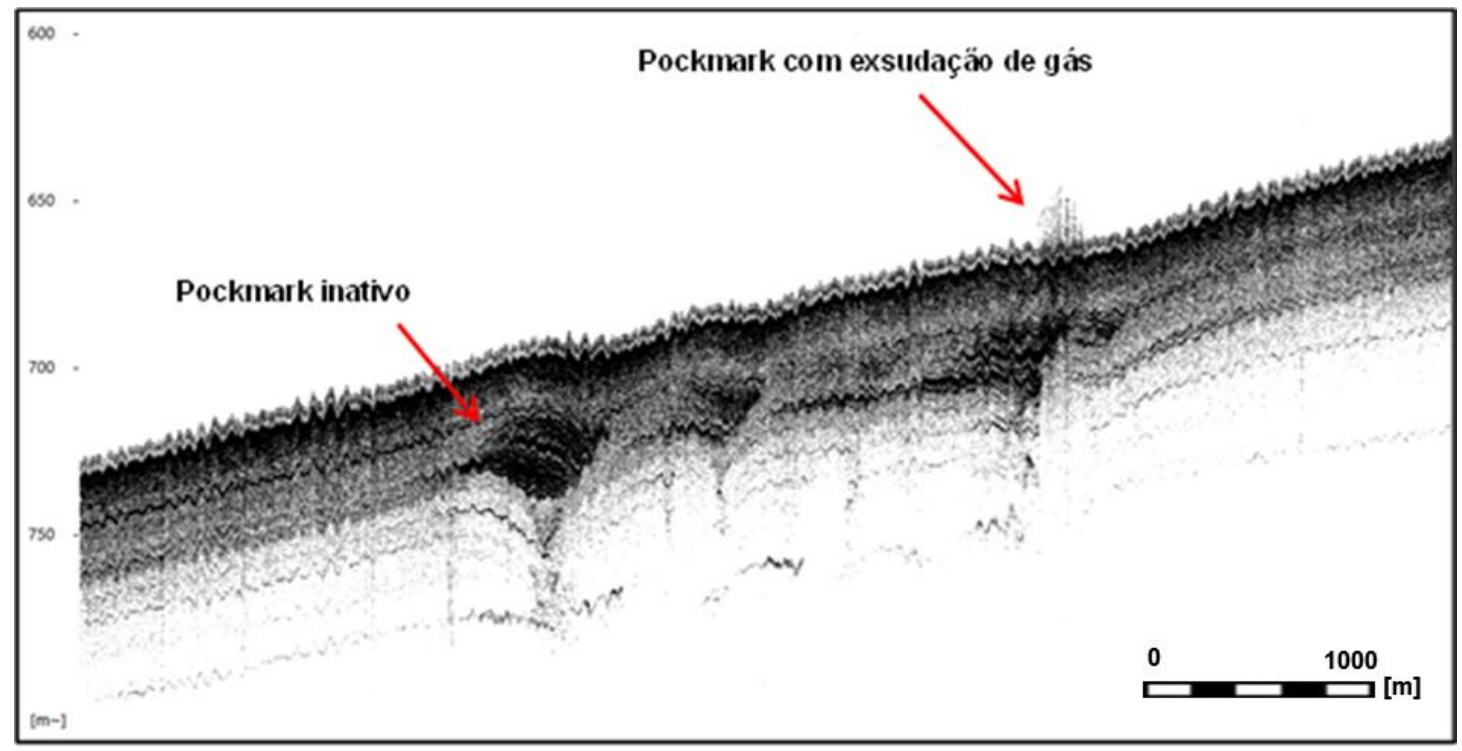

Figura 45. Perfil sísmico do Talude inferior da Seção 3 destacando o pockmark com exsudação de gás. 
Entre as isóbatas de 1200 metros a 1350 metros de profundidade observa-se a presença de canais e depósitos contorníticos no talude. As seções próximas a sudoeste apresentam canais mais expressivos, com mais de dois quilômetros de largura e trinta metros de profundidade (Figura 46). Nas seções a nordeste os canais são menos acentuados, conforme visualizado na Figura 47.

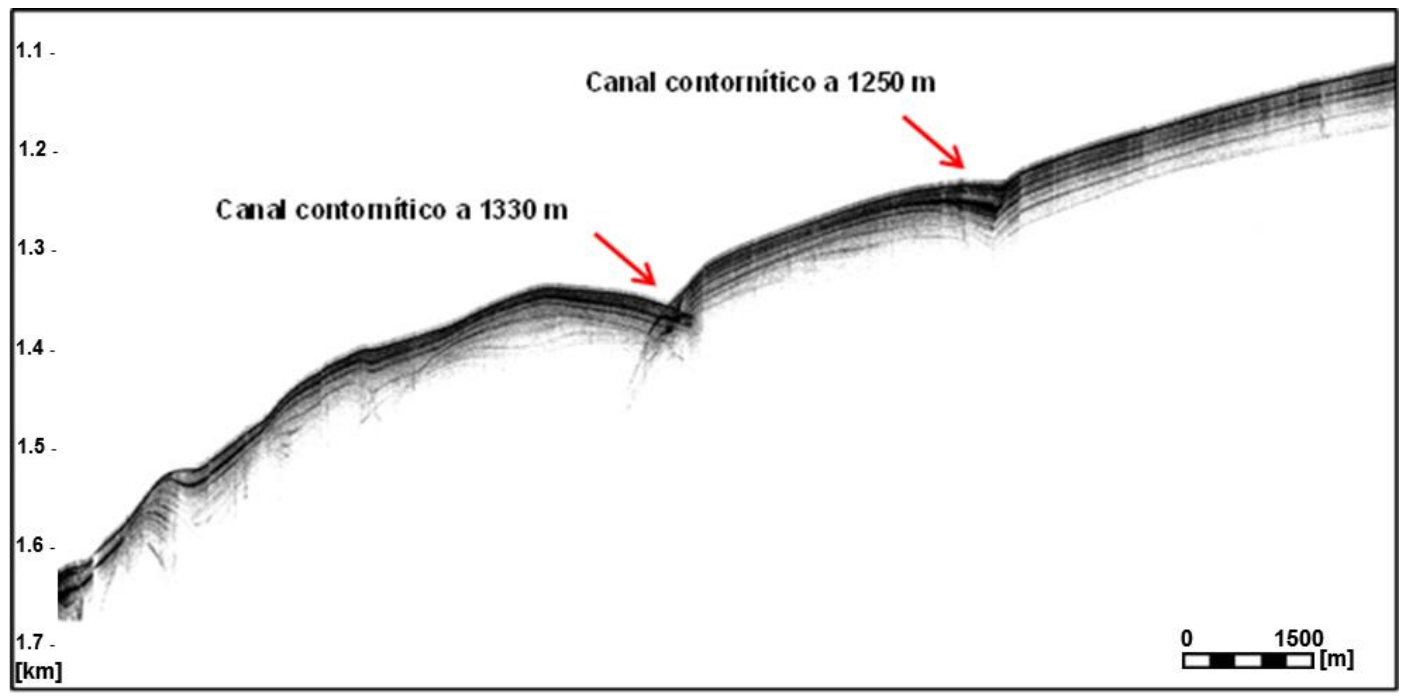

Figura 46. Perfil sísmico do Talude inferior da seção 5 destacando dois canais contornítico 1250 e $1330 \mathrm{~m}$.

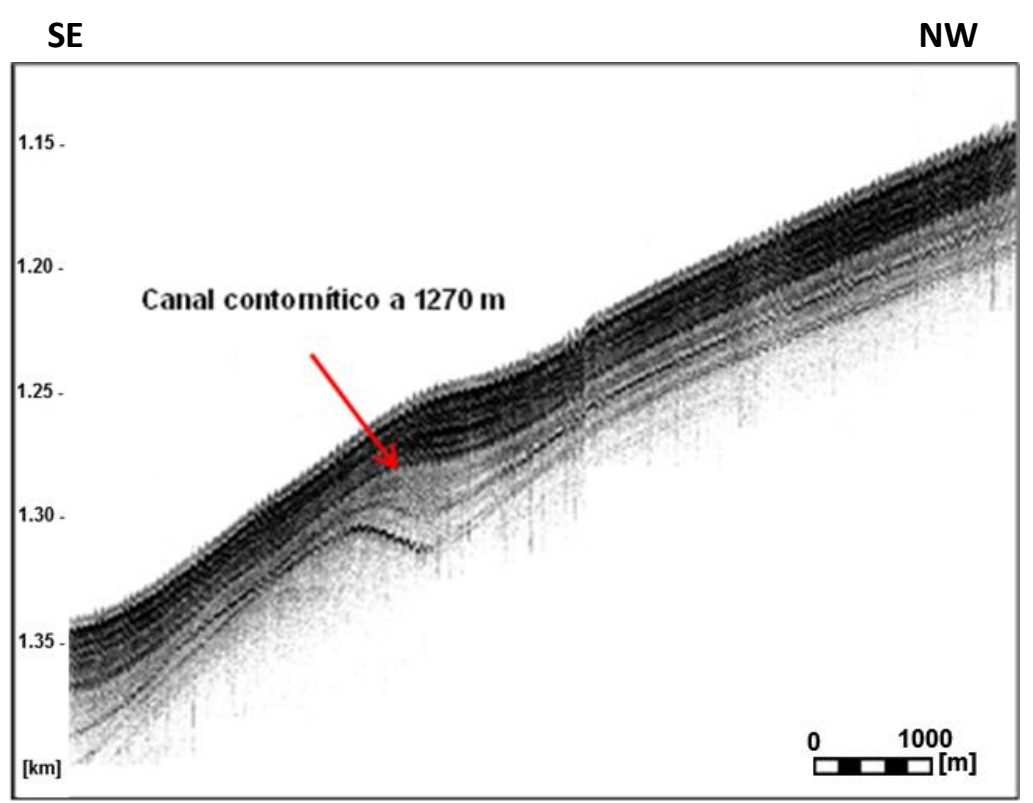

Figura 47. Perfil sísmico do Talude inferior destacando contornito na isóbata de $1270 \mathrm{~m}$. 
Na seção transversal T3, que está compreendida nesta mesma faixa, entre 1200 a 1350 metros, observavam-se os dois canais. O canal a sudoeste apresenta padrão de um canal contornítico, com seu depósito orientado para nordeste. Já o segundo canal a nordeste verifica-se que há componente de deformação tectônica no registro, sendo posteriormente recoberto por sedimentos mais recentes. Verifica-se que também há um fluxo que ali modela essa feição. (Figura 48).

Na seção transversal T4, compreendida pelas isóbatas de 1300 até 1450 metros, pode-se visualizar dois canais contorníticos a nordeste. $\mathrm{Na}$ extremidade a sudoeste, observa-se outro depósito contornítico. Na região central verificam-se duas elevações. Seus refletores sofrem deformações, no sentido de soerguimento. Tanto a sudoeste quanto a nordeste, desta elevação pode-se visualizar depósitos contorníticos com grande expressão lateral (Figura 49).

Na base do Talude Inferior há presença do Canal de Santos. Este canal contornítico, com grande expressão regional apresenta configuração diferenciada ao longo da base do talude. O seu flanco a montante (junto ao talude) apresenta refletores erodidos e sua inclinação apresenta variação, chegando a valores superiores a $4^{\circ}$. Seu flanco a jusante é composto por depósitos contorníticos. Após o Canal de Santos verificam-se inúmeros depósitos contorníticos, formados por outros canais subsidiários. Destacam-se três canais com dimensões expressivas, com mais de dois quilômetros de largura por cem metros de profundidade. Neste setor da base do talude, os refletores possuem padrão de conformidade, em alguns momentos são plano- 
paralelos e em outros ondulados. Eles são marcados, primeiramente, por um refletor com alta refletividade, seguido de um pacote com menor refletividade ou homogêneo, com espessura de 9 metros. Na porção mais profunda do pacote sedimentar encontra-se um pacote sedimentar com alta refletividade, com espessura de 10 metros em alguns locais, conforme ilustrados nas Figuras 50 a 55.

As seções transversais T5 e T6 estão localizadas a jusante do Canal de Santos, ou seja, no setor mais profundo da base do talude, sobre os depósitos contorníticos. Nestas seções verificam-se inúmeros canais que estão orientados perpendicularmente ao talude. Estes canais apresentam seus flancos erodidos, indicando que há presença de fluxos perpendiculares ao talude, conforme ilustrado nas Figuras 56 e 57. A seção T7 localizada na porção a nordeste da base do talude, verifica-se que seu flanco, junto ao talude, está erodido, formando a sua esquerda depósitos contorníticos na sua base, Figura 58. 


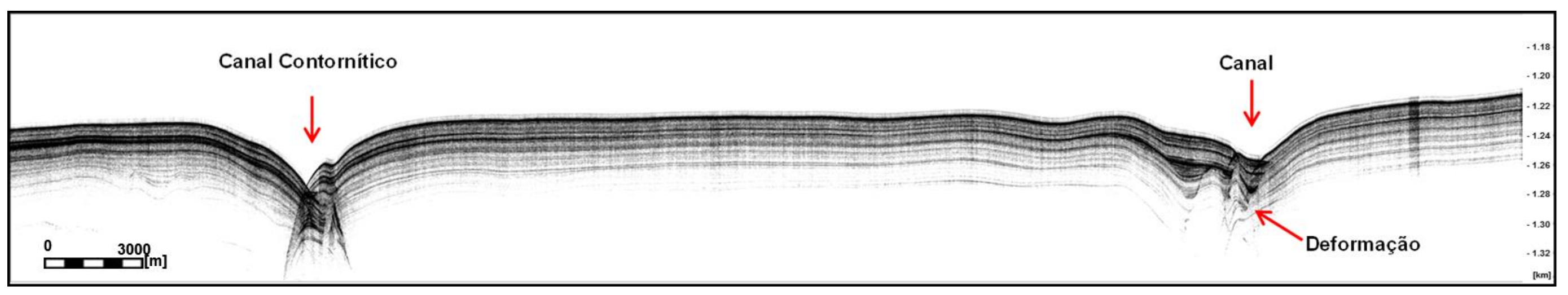

Figura 48. Perfil sísmico T3 paralelo ao Talude inferior destacando os dois canais.

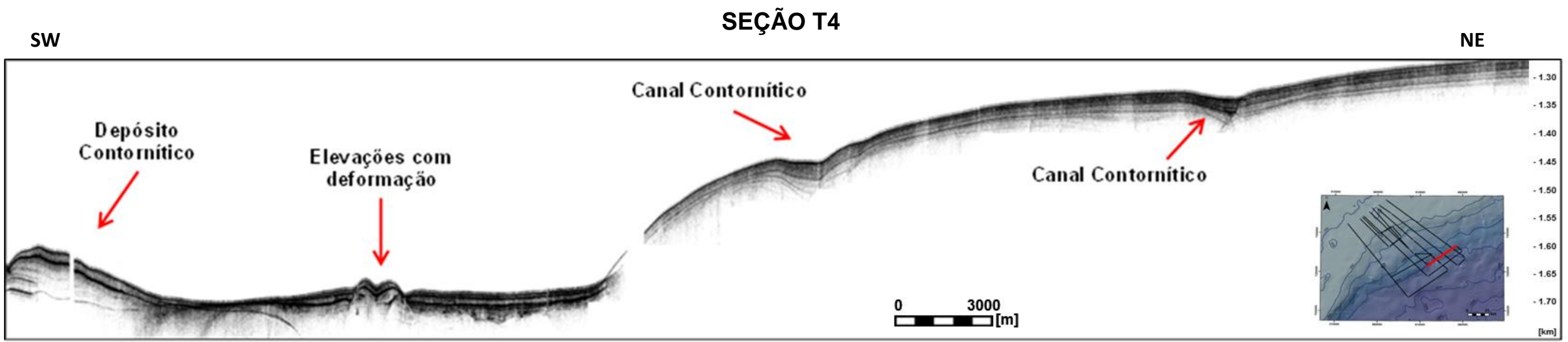

Figura 49. Perfil sísmico T4 transversal ao Talude, destacando feições contorníticas e elevações com deformação dos refletores. 
SEÇÃO 1

NW SE

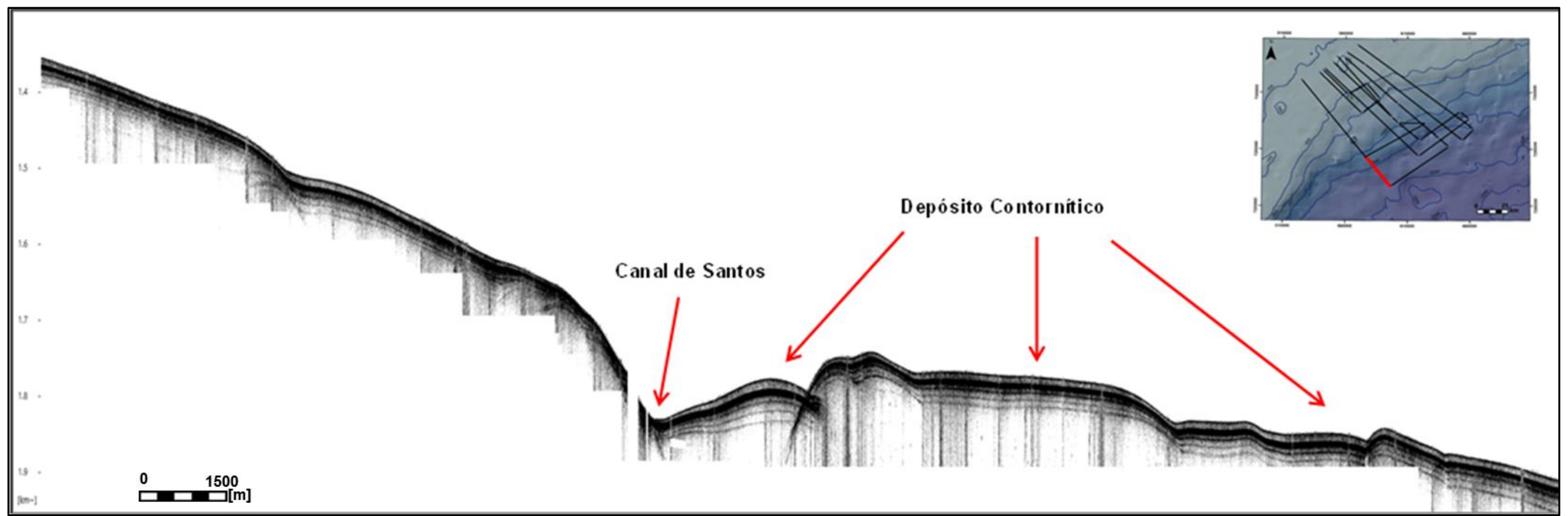

Figura 50. Perfil sísmico do Talude inferior da Seção 1, com destaque para o Canal de Santos e depósitos contorníticos. 


\section{SEÇÃO 4}

NW

SE

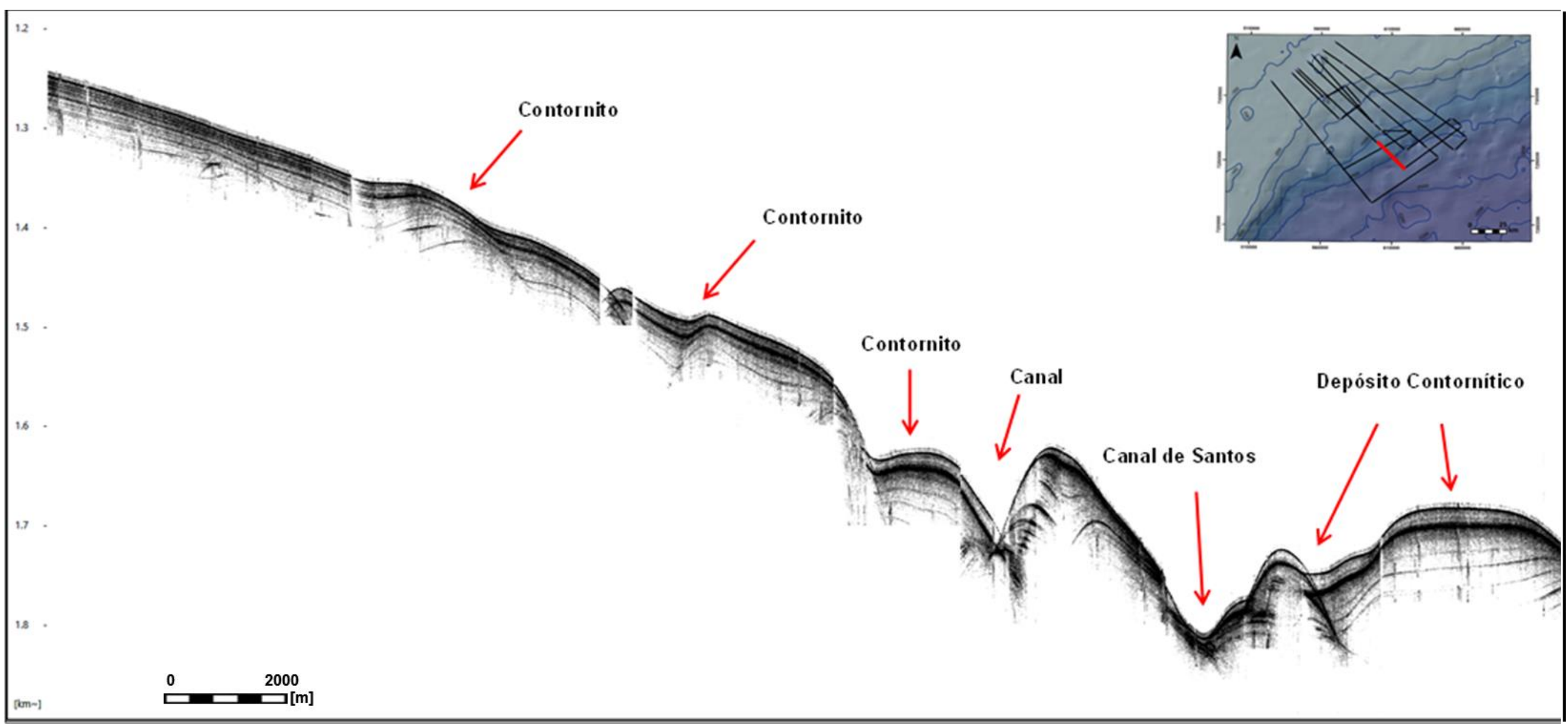

Figura 51. Perfil sísmico do Taludo inferior da Seção 4, com destaque a inúmeras feições contorníticas e ao Canal de Santos. 


\section{SEÇÃO 8}
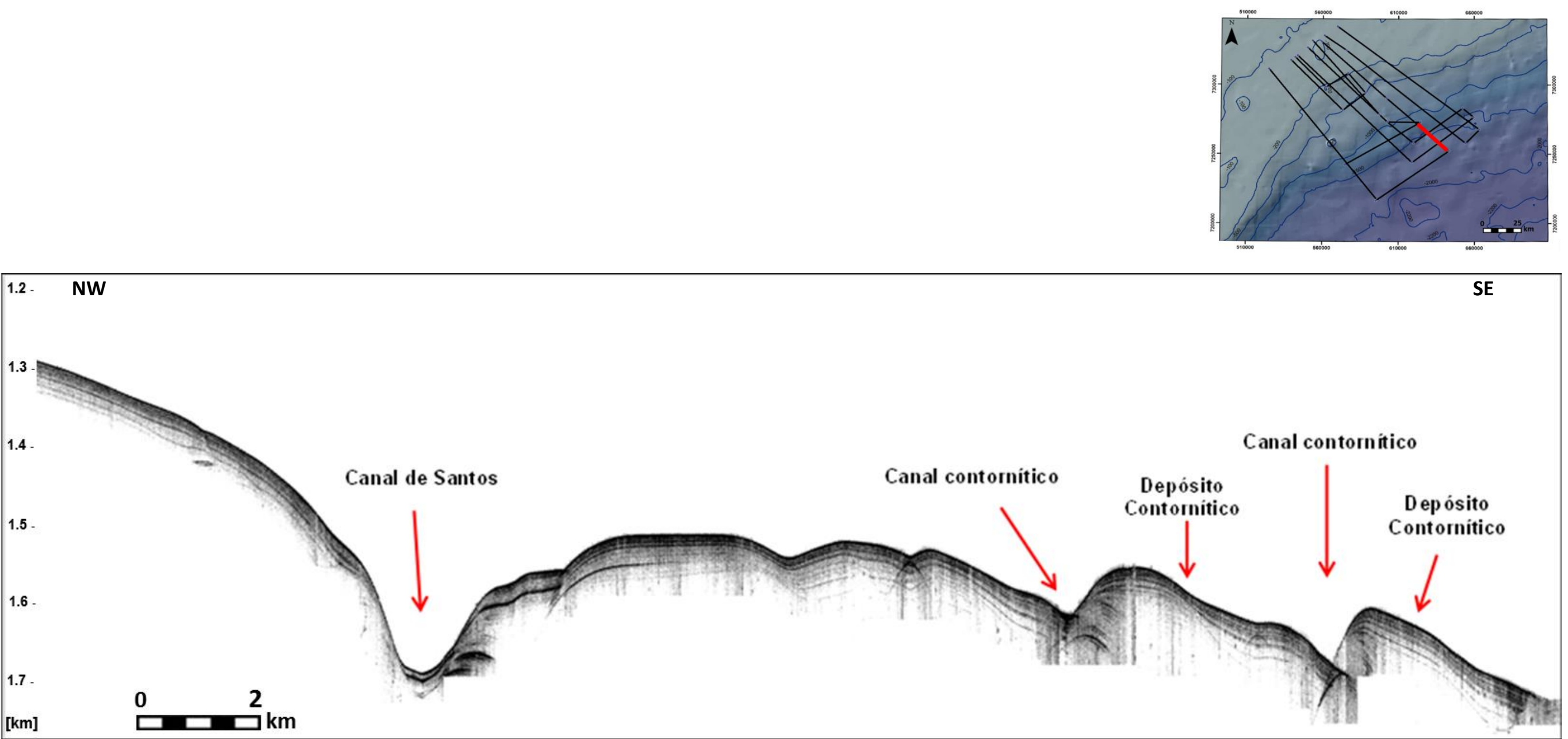

Figura 52. Perfil sísmico do Taludo inferior da Seção 8, com destaque ao Canal de Santos, canais e depósitos contorníticos. 


\section{SEÇÃO 9}
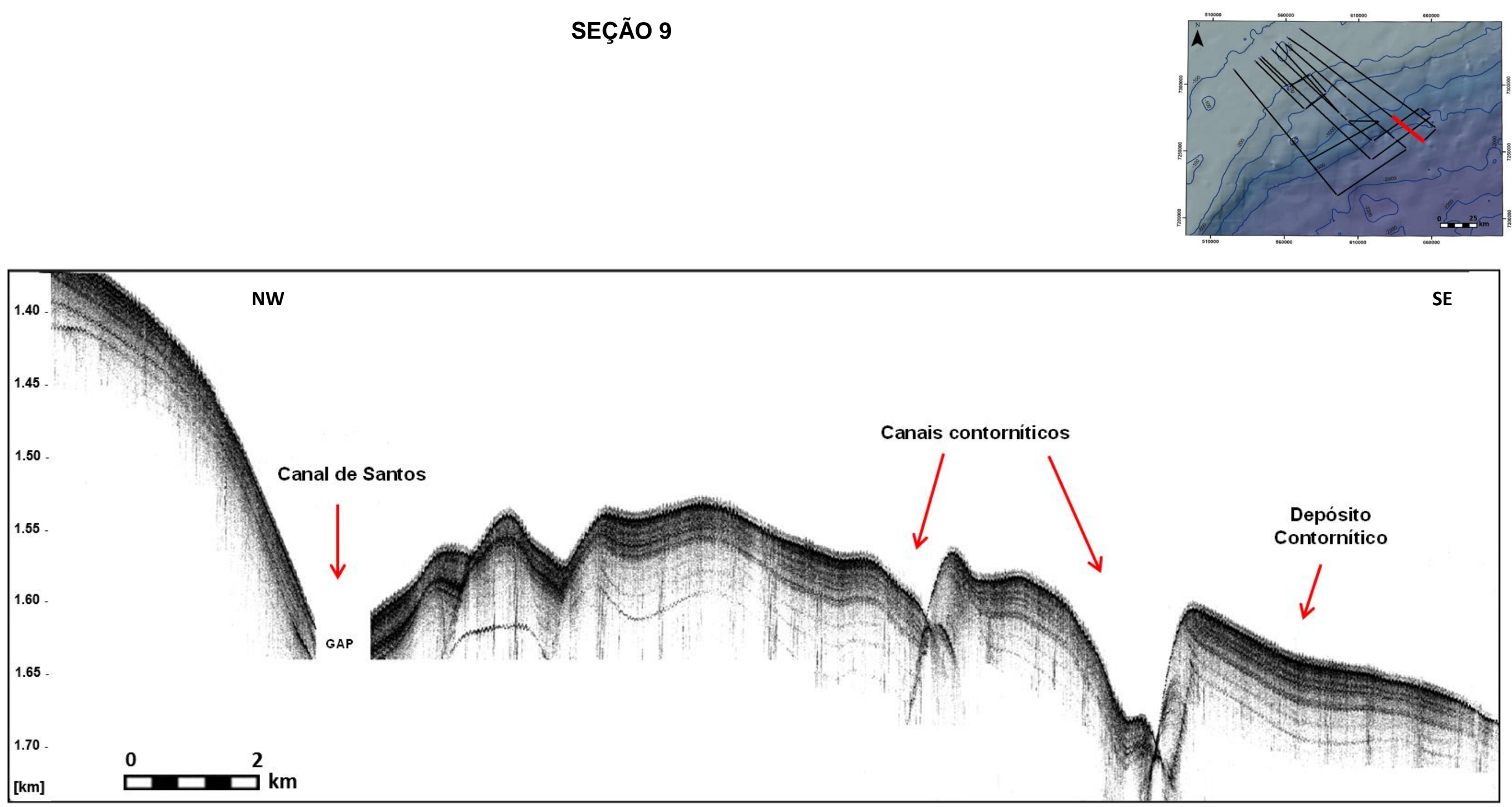

Figura 53. Perfil sísmico do Taludo inferior da Seção 9, com destaque ao Canal de Santos, canais e depósitos contorníticos. 




Figura 54. Perfil sísmico do Taludo inferior da Seção 10, com destaque ao Canal de Santos, canais e depósitos contorníticos. 


\section{SEÇÃO 11}

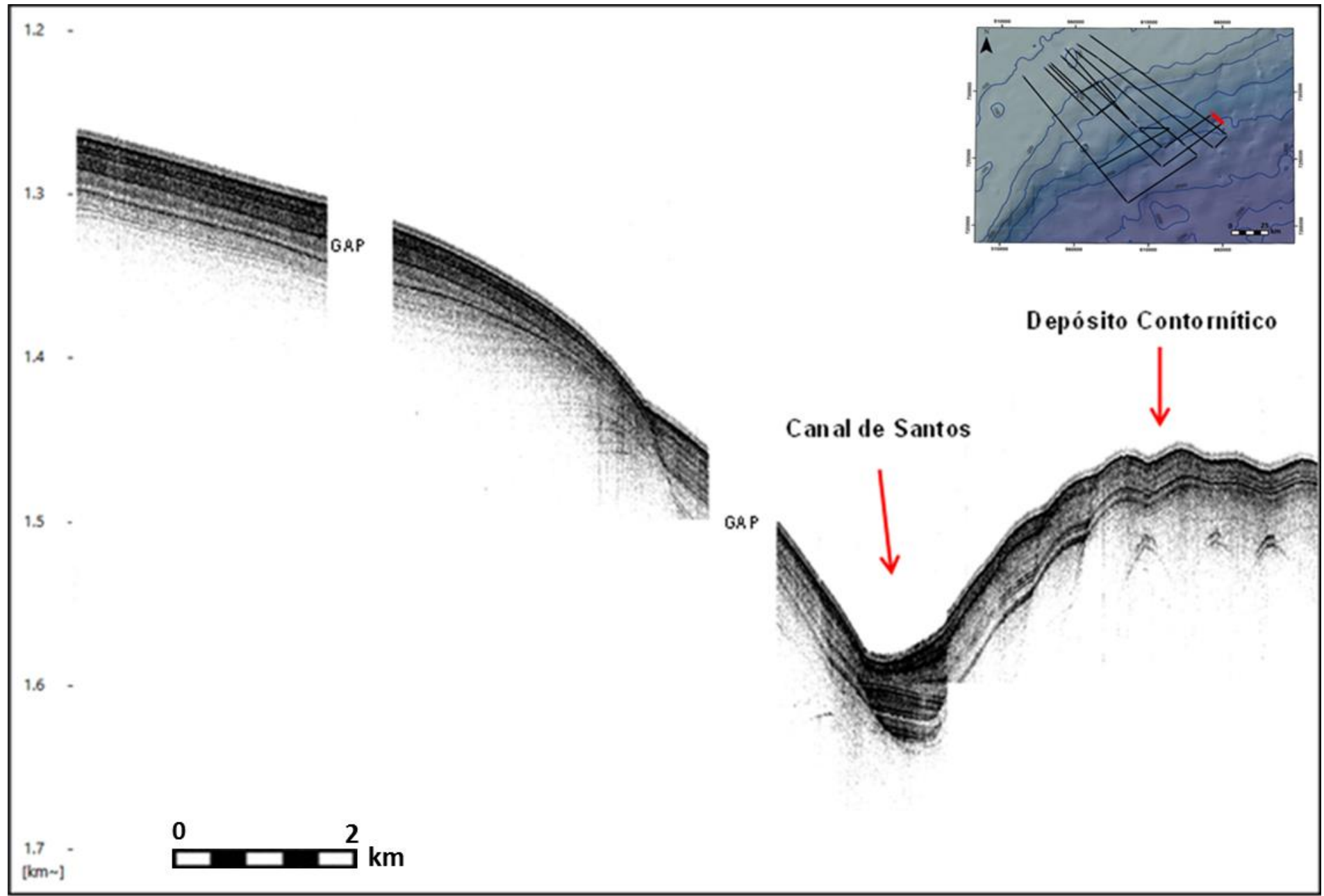

Figura 55. Perfil sísmico do Taludo inferior da Seção 11, com destaque ao Canal de Santos e depósito contornítico. 
SEÇÃO T5


Figura 56. Perfil sísmico T5 transversal ao Taludo inferior, com destaque aos inúmeros canais formados na área.

\section{SEÇÃO T6}
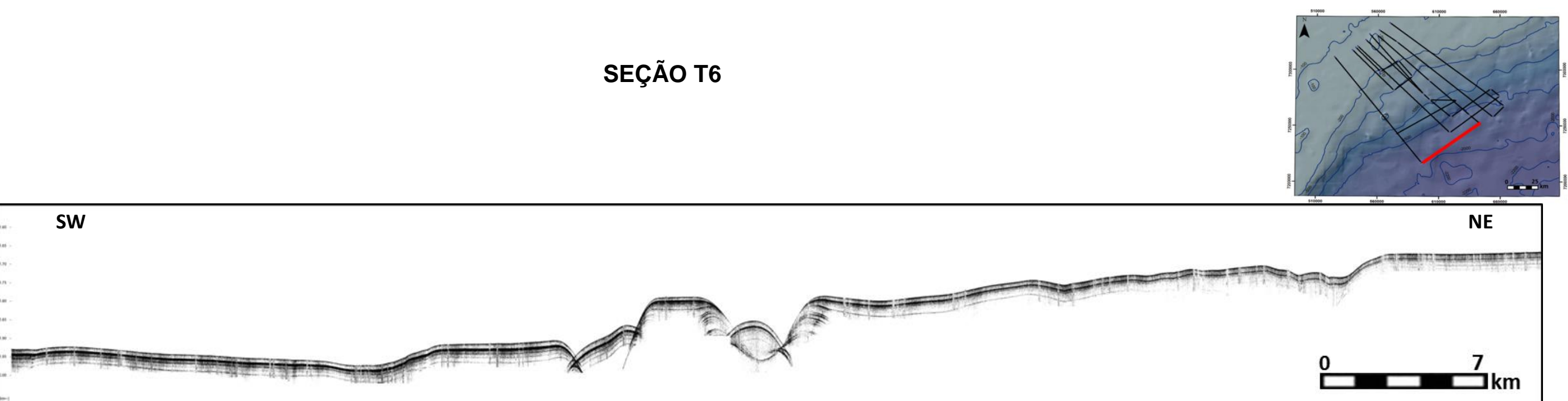

Figura 57. Perfil sísmico T6 transversal ao Talude inferior destacando canais perpendiculares ao talude. 


\section{SEÇÃO T7}

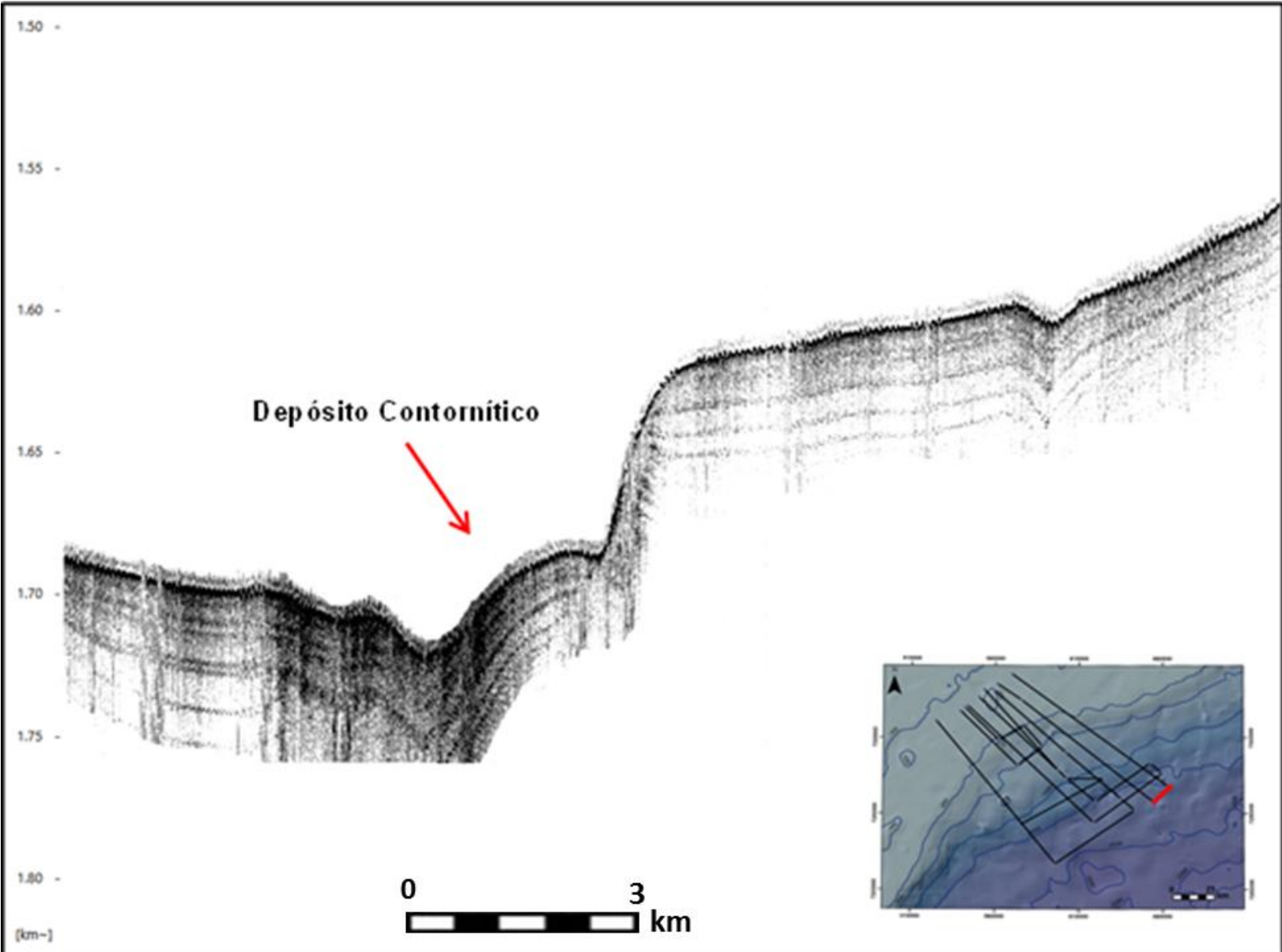

Figura 58. Perfil sísmico T7 transversal ao Talude inferior, destaque para deposito contornítico e refletores erodidos no setor superior. 


\section{DISCUSSÃO}

A região estudada apresenta grande variabilidade morfológica e de processos sedimentares. Essa variabilidade é herdada de seu arcabouço estrutural bem como das variações eustáticas e dos processos oceanográficos incidentes ao longo do tempo.

Verifica-se que a região não é simétrica em relação à inclinação e profundidade. A região mais a sudoeste apresenta maiores inclinações e profundidades, quando comparada ao setor nordeste. Essa diferença se deve à forma em arco das isóbatas, configurando um anfiteatro no talude superior. $O$ setor a nordeste demonstra nitidamente essa característica quando observadas as seções transversais T4, T5, T6 e T7. Esse formato côncavo da área provoca alterações nos padrões da circulação, forçando meandramentos e acentuando os processos erosivos provocados pelas correntes de contorno.

A Plataforma Continental Externa apresenta morfologia irregular que predomina em toda área de estudo. As irregularidades morfológicas indicam a atuação de processos erosivos relacionados aos períodos de exposição subaérea durante períodos regressivos e posteriormente afogamento em períodos transgressivos.

A determinação da profundidade da quebra da plataforma é de difícil definição, uma vez que a morfologia da plataforma externa e inclinação do talude superior são irregulares devido à ocorrência de forte erosão. Utilizandose métodos clássicos (Stanley e Moore, 1983) para determinar a quebra de plataforma e verificou que, em média a profundidade apresenta valor de -155 metros. 
A morfologia do fundo é marcada por ser extremamente irregular, com presença de escarpas, paleocanais e depressões erosivas e montiformas (e.g. Figuras 12 ,15). Essa morfologia irregular, que conferem um fundo corrugado, é oriunda de sedimentos e bioconstruções carbonáticas, presentes principalmente na plataforma externa (Dias et al., 1982; Figueiredo Jr. e Tessler, 2004; Reis et al., 2014). Essas formações carbonáticas são opacas ao sinal acústico e assim não há a penetração do sinal do chirp.

Nos registros sísmicos, observa-se que no setor mais interno da Plataforma Continental Externa ( 120 a 130 metros) ocorrem refletores planoparalelos, possivelmente associados a depósitos do Pleistoceno Superior. Essa sequência forma superfícies erosivas, novamente interpretadas como características do período de máxima exposição subaérea da plataforma continental no ultimo máximo glacial (LGM). Posteriormente parte desta sequência ao longo da Plataforma externa foi recoberta por construções carbonáticas. Estes depósitos carbonáticos teriam sido formados durante a Transgressão Flandriana durante períodos de estilização do nível do mar (Kowsmann et al., 1976; Kowsmann et al., 1978; Costa et al., 1988).

Há presença marcante em quase todas as seções de montiformas, junto à isobáta dos 130 metros, com cerca de $10 \mathrm{~m}$ de altura e mais de 1000 metros de extensão. Estas feições podem estar relacionadas como sendo resultado de processos de retrabalhamento e nova deposição de sedimentos, ao longo de antigas linhas de praia da última transgressão Pleistoceno-Holoceno, e que posteriormente foram recobertas por sedimentos carbonáticos, preservando-os (Kowsmann et al., 1978; Costa et al.,1988). Outra feição que se destaca em várias seções é uma montiforma, localizada bem próxima à quebra da 
plataforma ( 150 m). Essa escarpa tem características de natureza biogênica e em muitas seções delimita a quebra da plataforma (e.g. Figuras 12 e 15).

Após a quebra da Plataforma Continental localiza-se um canal paralelo ao Talude. Ele está compreendido entre a porção central e a sudoeste da área de estudo. Nas proximidades da porção central sua feição tem características de escarpa e ao longo do talude se transforma em um canal desenvolvido seguindo para sudoeste. Nas proximidades das seções mais a sudoeste, o canal possui profundidades superiores a 20 metros e seus flancos são altamente erodidos. Outro canal erosivo é visualizado nas proximidades das isóbatas de 225 a 270 metros e que se desenvolve também paralelamente ao Talude. Ao contrário do primeiro, esse canal inicia-se em porções mais profundas, a $270 \mathrm{~m}$ e termina na porção mais rasa a 225 metros. Este canal não está ativo ao longo de todo talude, já que em algumas seções ele se encontra parcialmente preenchido. Destaca-se que este canal não permaneceu ao longo do tempo no seu eixo atual, pois foi possível verificar a migração para porções mais profundas ao longo do tempo, conforme visualizado na Figura 59.

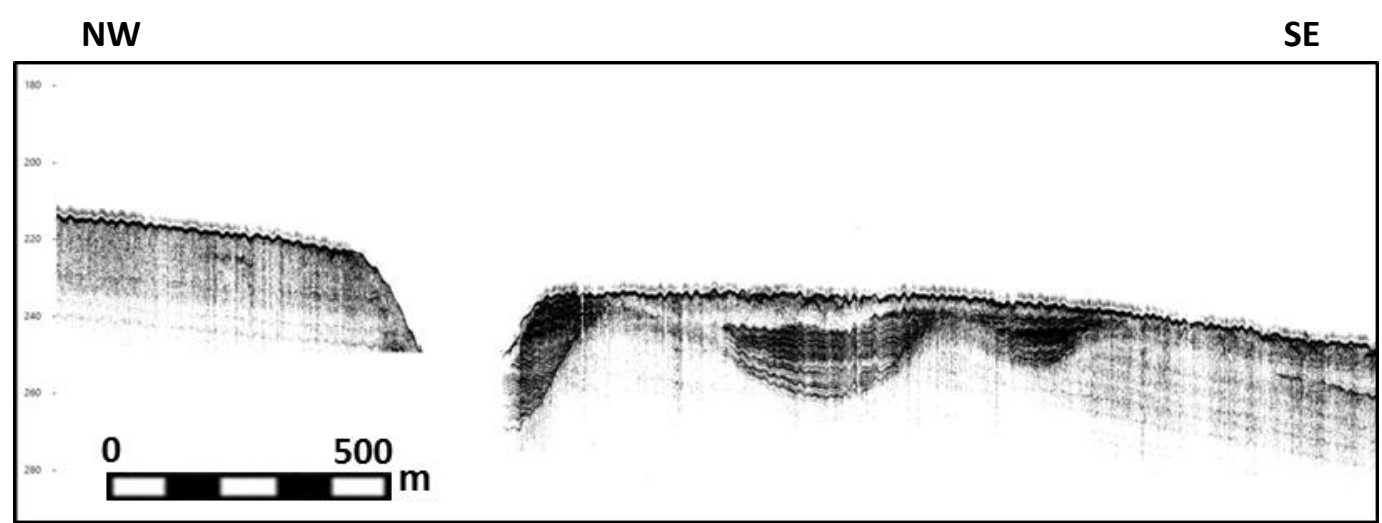

Figura 59. Canal localizado sobre o talude superior. Verifica-se a presença de três paleocanais. 
A presença de canais ativos, paralelos ao talude, associados com superfícies erosivas, no inicio do talude superior e na plataforma externa são evidências que indicam que a região sofreu forte processo de erosão pela Corrente do Brasil, ao longo do tempo. Devido a suas características de corrente de contorno, a Corrente do Brasil impede que ocorra deposição de sedimentos pelágicos na região. Associada ao seu comportamento meandrante e/ou vórtices, ela adentra a plataforma externa, erodindo a sua superfície, afastando-se em seguida, por conservação de momentum. Pode-se dizer que o comportamento da Corrente do Brasil, após sua inflexão em Cabo Frio, age como se fosse uma "enceradeira" na plataforma externa e talude superior, ao longo da Bacia de Santos (Mahiques et al., 2004).

As variações relativas do nível do mar fazem que o núcleo da Corrente do Brasil se desloque ao longo da do tempo. Em fases transgressivas o núcleo da Corrente do Brasil desloca-se para regiões mais interiores da Plataforma Continental Externa. Já em fases regressivas a Corrente do Brasil desloca-se mais para o exterior do Talude. Assim, pode-se explicar migração dos paleocanais ao longo do talude e intensificações dos processos erosivos. Mahiques et al. (2007) e Nagai et al. (2010) realizaram estudos em testemunhos na região do Talude superior, indicando que durante o recuo do nível do mar no LGM, ocorreu o aumento da produtividade e diminuição da temperatura da superfície do mar, podendo determinar o deslocamento da Corrente do Brasil para regiões mais distantes da quebra da plataforma. No período transgressivo pós-LGM, ocorreu o aumento da temperatura da superfície e deslocamento da Corrente do Brasil para porções mais internas da PCE (Figura 60). 
(a)

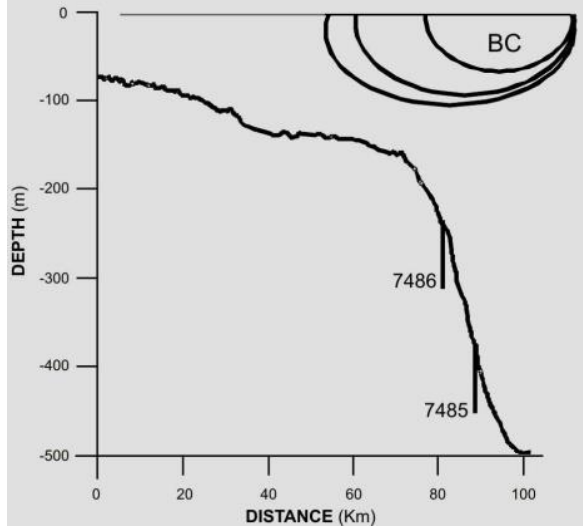

(b)

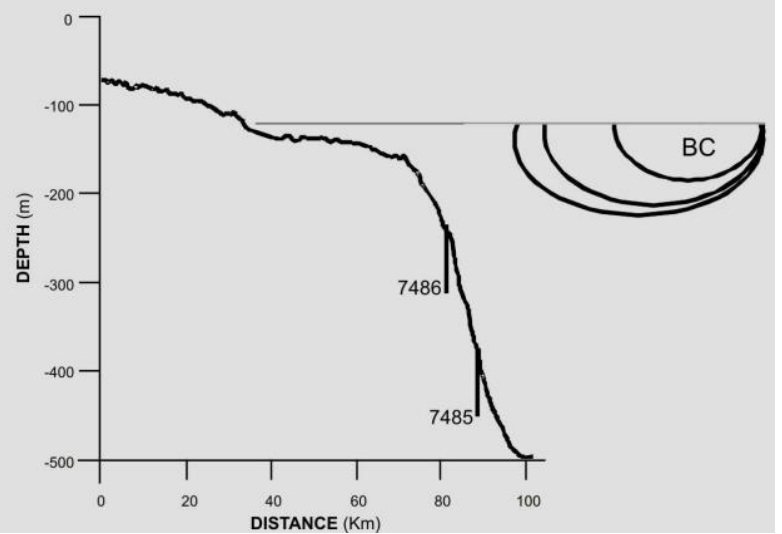

Figura 60. Modelo esquemático da localização do núcleo da CB. (A) períodos transgressivos e (B) regressivos (extraído de Mahiques et al., 2007)

Abaixo dos 300 metros observa-se mudança no padrão deposicional. A partir dessa profundidade ocorre inicialmente a deformação do pacote sedimentar, podendo indicar um possível fluxo gravitacional que, posteriormente, muda para um padrão predominantemente de estruturas internas plano-paralelas.

$\mathrm{Na}$ isóbata dos 350 até 550 metros observa-se o domínio, em toda região, de ondas de sedimentos na base dos registros sísmicos. Sugere-se que essas ondas de sedimento possuam origem provenientes de correntes turbidíticas, tal como descrito por Lee et al. (2002); Wynn e Stow (2002). As ondas de sedimento possuem espessuras da ordem de 35 metros, assimétricas e com eixo ascendente. O pacote sedimentar desta região pode ser interpretado como possuindo quatro unidades. A primeira na base como sendo interface entre o fluxo de turbidez e unidades pretéritas. Essa unidade devido ao atrito com unidades mais antigas sofre uma deformação menor e apresenta refletividade mais baixa. A segunda unidade corresponde aos 
depósitos do fluxo formando as ondas de sedimento. A terceira unidade constitui um pacote de sedimento, transparente ao sinal sísmico provavelmente de natureza hemipelágica. A quarta e última unidade, corresponde à sequência superior, constituída por sedimentos com maior refletividade e estruturas planoparalelas, conforme pode ser ilustrado na Figura 61.

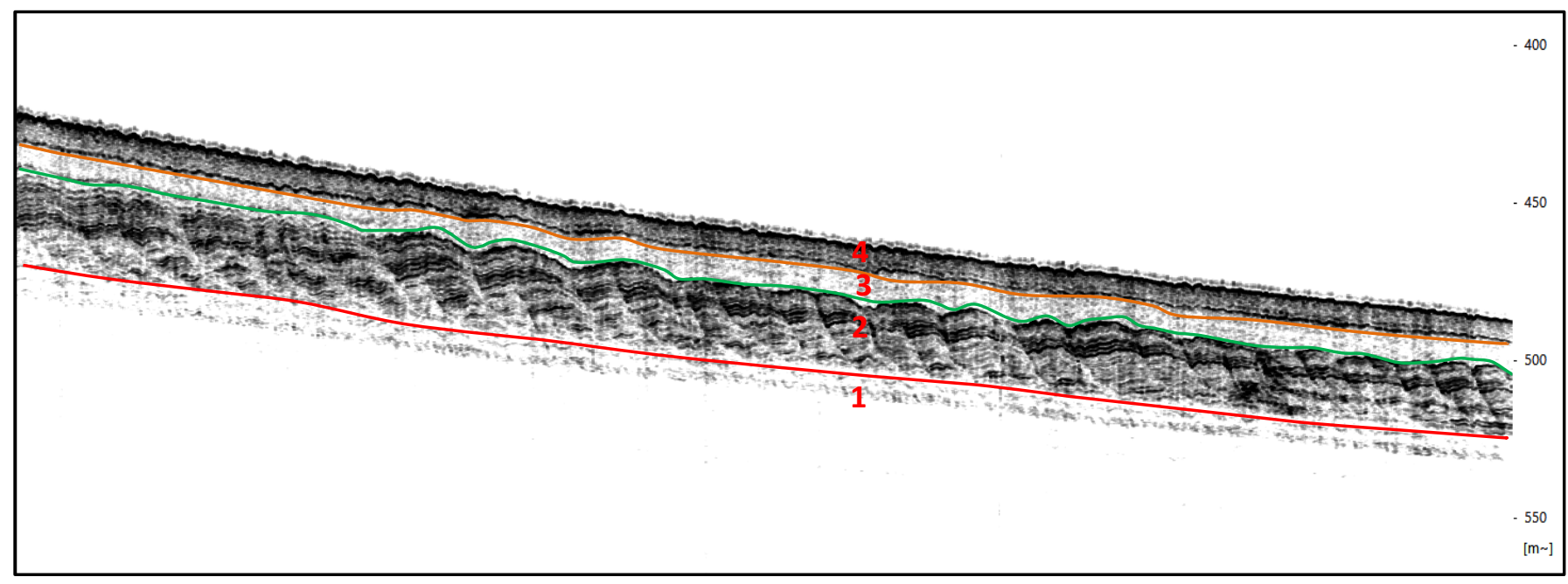

Figura 61. Seção sísmica com presença de ondas de sedimento na sua base. As marcações refletem as unidades deposicionais ao longo da coluna.

Na região entre as isóbatas 600 a 850 metros apresenta mudanças nas feições de fundo, com o aparecimento de inúmeros pockmarks. Essa ocorrência verifica-se em todas as seções, caracterizando continuidade lateral dessas feições na área de estudo. Na região foram identificados três tipos de ocorrência. A primeira, pockmarks desenvolvidos e com exsudações de gás, como visto nos registros sísmicos (e.g. Figura 44). O segundo tipo de ocorrência corresponde a pockmarks desenvolvidos, mas sem a presença de exsudação de gás. Por último é identificada a presença de pockmarks subsuperficiais, soterrados por sedimentos atuais. Essa evidência é 
demonstrada, nos registros sísmicos, através de estruturas de escape e ou trapeamento de gás (e.g. Figura 45). Nas proximidades da isóbata de 830 metros ocorrem os pockmarks com maiores dimensões; muitas vezes sua forma se assemelha ao de um canal contornítico mas, devido a suas variações laterais, associadas à presença de gás, optou-se por refutar essa hipótese. Observa-se que há um alinhamento destes pockmarks na área de estudo, não estando dispostos aleatoriamente. Eles seguem alinhamento SW para NE, no azimute 50 graus. Isso leva a crer, que os pockmarks acompanham os principais alinhamentos da margem continental brasileira, onde ocorre a migração do gás e seu afloramento na superfície. Essa falha pode estar associada à halocinese da bacia, gerando o soerguimento de diápiros de sal. Mahiques et al. (2015) realizaram mapeamento de pockmarks no setor sul da Bacia de Santos e determinaram a continuidade dos alinhamentos de pockmarks, associados a diápiros de sal.

Entre as isóbatas de 500 a 1000 metros não foram encontradas, ao longo do Talude, feições erosivas oriundas das correntes de contorno. Os sedimentos depositados apresentam padrão de conformidade, com refletores rítmicos de maiores reflexões, com estruturas plano-paralelas. Provavelmente este padrão deve estar relacionado, por ser uma profundidade na qual ocorrem menores intensidades de correntes de contorno. De fato, abaixo dos 400 metros a Corrente do Brasil se enfraquece e, devido ao cisalhamento com o início da Corrente de Contorno Intermediária $(\mathrm{CCl})$, apresenta velocidades muito baixas (Figura 62).

Entre as isóbatas de 1000 e 1300 metros a região sofre forte influência do núcleo da $\mathrm{CCl}$, com a intensificação da corrente. $\mathrm{A} C \mathrm{Cl}$ age sobre a região 
até aproximadamente 1800 metros, onde posteriormente a Corrente de Contorno Profunda (CCP), com sentido oposto (a sudoeste), estabelece seu domínio (Figura 62).

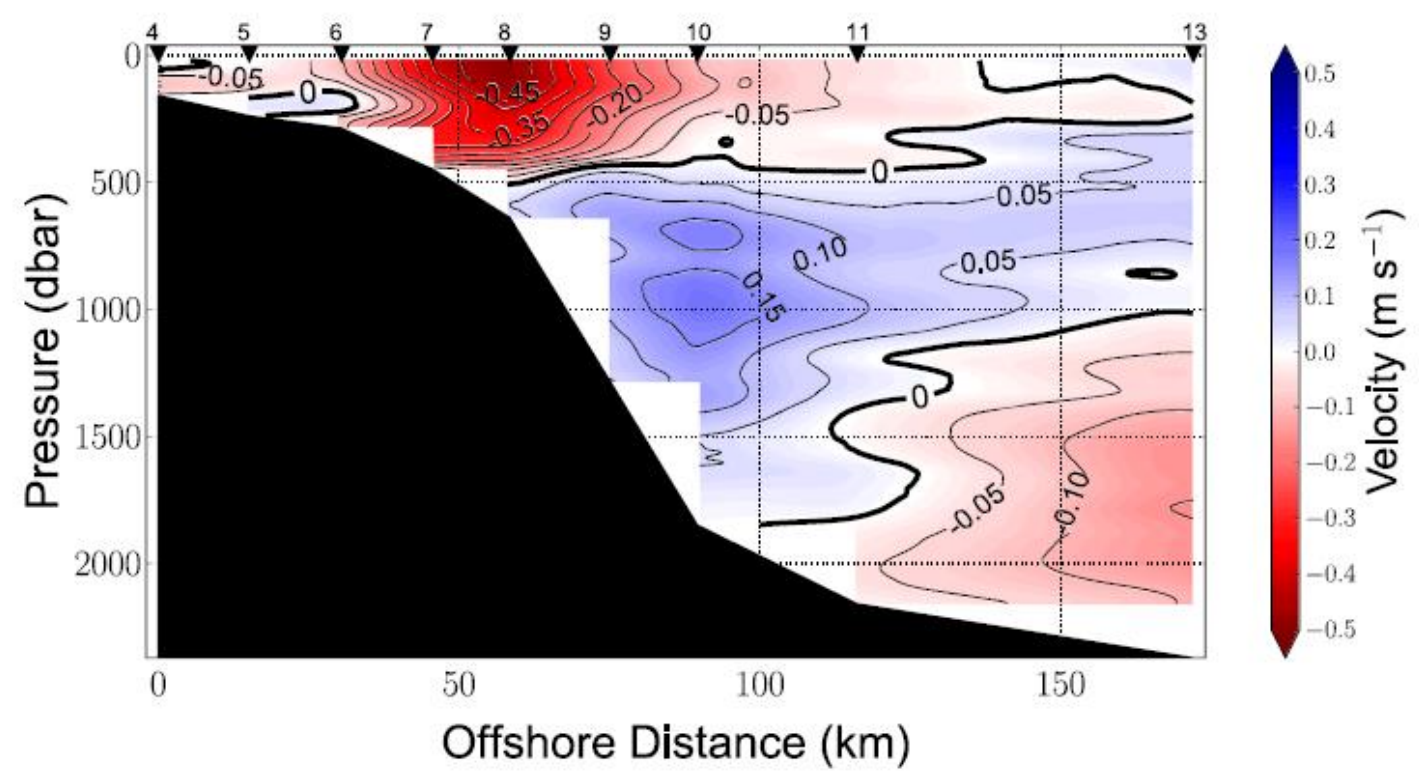

Figura 62. Seção transversal da velocidade na Bacia de Santos. Velocidades negativas são orientadas para sudoeste (Biló et al. 2014).

Logo abaixo da isóbata de 1000 metros de profundidade inicia-se o domínio dos contornitos, caracterizados por vários canais e depósitos associados, tendo como origem as correntes de contorno de fundo, que acabam erodindo e retrabalhando os sedimentos de fundo. O primeiro canal contornítico bem marcado localiza-se nas seções mais a sudoeste, junto à isóbata de $1250 \mathrm{~m}$. Este canal não exerce continuidade lateral nas seções a nordeste. O segundo canal contornítico com expressão está localizado próximo a isóbata de 1300 metros de profundidade. Este canal é visualizado em todas as seções que cortam o Talude inferior. Observa-se que a amplitude deste canal diminui conforme se desloca para nordeste. Observa-se ainda que a 
intensidade da e/ou direção das correntes de fundo, pode ter sofrido alterações ao longo do tempo, expresso pela migração do seu eixo principal e da sua amplitude para profundidades mais rasas no setor a nordeste. Também é possível verificar, ao longo do Talude inferior, que há presença de inúmeros canais contorníticos que diminuíram sua feição acanalada ou então sofreram soterramento ao passar do tempo, o que indica modificações temporais na dinâmica de fundo.

A área de estudo apresenta uma morfologia côncava, principalmente no setor mais profundo, e as correntes de fundo acabam sofrendo deflexões para interior e exterior desta reentrância. Tal evidência pode explicar a presença de canais contorníticos perpendiculares ao talude, conforme pode ser verificado na seção transversal T3.

Após a isóbata de 1300 metros, a inclinação do Talude aumenta e seu flanco tende apresentar processos erosivos mais evidentes. Esta região achase sob o domínio do Canal de Santos. Este canal foi descrito por Duarte e Viana (2007) e se desenvolve paralelamente ao Talude por mais de $200 \mathrm{~km}$. O canal é classificado como contornítico e está associado à falha regional do Cabo Frio. Logo está encaixado sobre esta falha impossibilitando que ocorra uma migração lateral. O Canal de Santos se estende por toda área de estudo e sua largura apresentou variações entre 1.44 até $3.55 \mathrm{~km}$. Suas dimensões são maiores nas seções a nordeste e menores nas porções centrais da área de estudo. Sua profundidade média também varia ao longo de seu eixo, onde a média é de aproximadamente 100 metros e seu setor mais profundo possui 170 metros. O seu flanco a montante tem a tendência de apresentar refletores com estruturas erosivas e possui altos valores de inclinação. Já seu flanco 
direito é composto de um depósito contornítico. Ao analisar sua calha, verificase que há mudanças no padrão de sedimentação, ao longo do tempo. Primeiramente verifica-se um padrão de deposição plano-paralelo e posteriormente se altera para um padrão em ondulado no formato em "U". Essa mudança no padrão indica a ocorrência de alterações no decorrer da sua história (Figura 63).

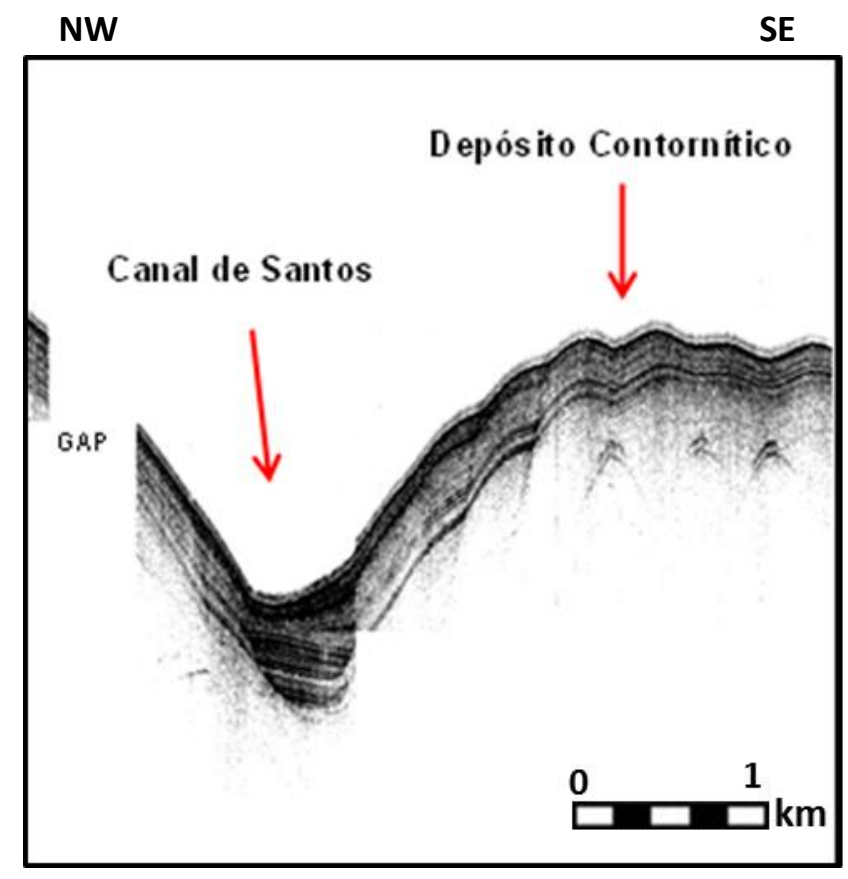

Figura 63. Seção sísmica do Canal de Santos, onde visualiza-se a mudança no padrão de deposição plano-paralelo para ondulado, junto a calha do canal.

Logo após o Canal de Santos, no setor mais profundo da área de estudo, verifica-se uma mudança morfológica do fundo. Primeiramente há uma diminuição do gradiente de inclinação. Posteriormente há inúmeros canais e depósitos contorníticos. Esses depósitos e canais apresentam feições de grande expressão, com quilômetros de largura. Alguns canais possuem mais de $3 \mathrm{~km}$ de largura e 150 metros de profundidade. 
Verifica-se que as correntes de fundo erodem antigos depósitos contorníticos. Esses novos canais contorníticos geram depósitos contorníticos em direção ao setor mais profundo da bacia (e.g. Figura 52).

Através dos registros dos perfis transversais no setor mais profundo do talude, pode-se verificar inúmeros canais com dimensões de quilômetros e profundidades superiores a 50 metros. Esses canais podem ser derivados da ação do Canal de Santos, onde ocorre a formação de inúmeros canais tributários perpendiculares, ao longo o seu eixo. Duarte e Viana (2007), através de sísmica 3D, demonstram a presença dos canais tributários durante as diversas unidades deposicionais ao longo do tempo. (Figura 64).



Figura 64. Bloco sísmico 3D da região do Canal de Santos. Setas azuis demonstrando o fluxo durante sequencia U5 e setas em vermelho, fluxos perpendiculares ao talude formando canais tributários (Duarte e Viana, 2007). 
Outra possível hipótese para esses inúmeros canais, seria relacionada à posição dessas seções transversais, cortando os vários depósitos contorníticos alongados, com formatos de montes que se afinam ao longo da distância. Assim, esses montes formam canais imbricados entre vários depósitos, que posteriormente foram erodidos e formando canais ativos.

Verificou-se que a morfologia da área de estudo sofre influência de tectonismo proveniente da halocinese. Além de uma possível falha que gerou inúmeros pockmarks, também pode ser visualizado no talude inferior, nas seções T3 e T4 a deformação dos refletores até superfície (Figura 65). Estudos realizados por inúmeros pesquisadores (Moreira et al., 2007; Caldas e Zalán, 2009) descrevem que a região abaixo dos 1200 metros de profundidade sobre essa influencia da halocinese, gerando inúmeras elevações topográficas e afloramentos de diápiros de sal.
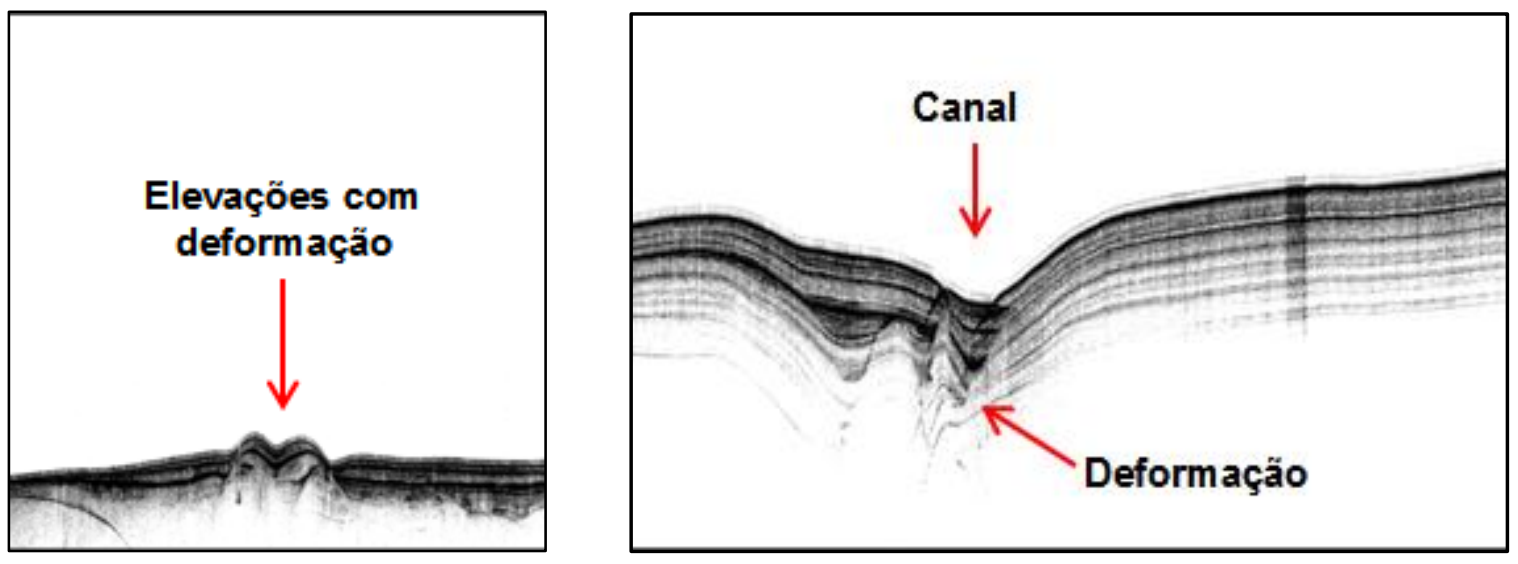

Figura 65. Deformação dos refletores nas seções sísmicas T3 e T4. 
- MODELO MORFOLÓGICO E SEDIMENTAR

Após uma análise integrada dos dados batimétricos e sísmicos gerou-se um modelo morfológico e sedimentar com suas forçantes para a área de estudo. A área pode ser subdivida em setores, com suas principais características ao longo da Plataforma Continental Externa e o Talude. A Figura 66 ilustra um bloco esquemático com as principais características.

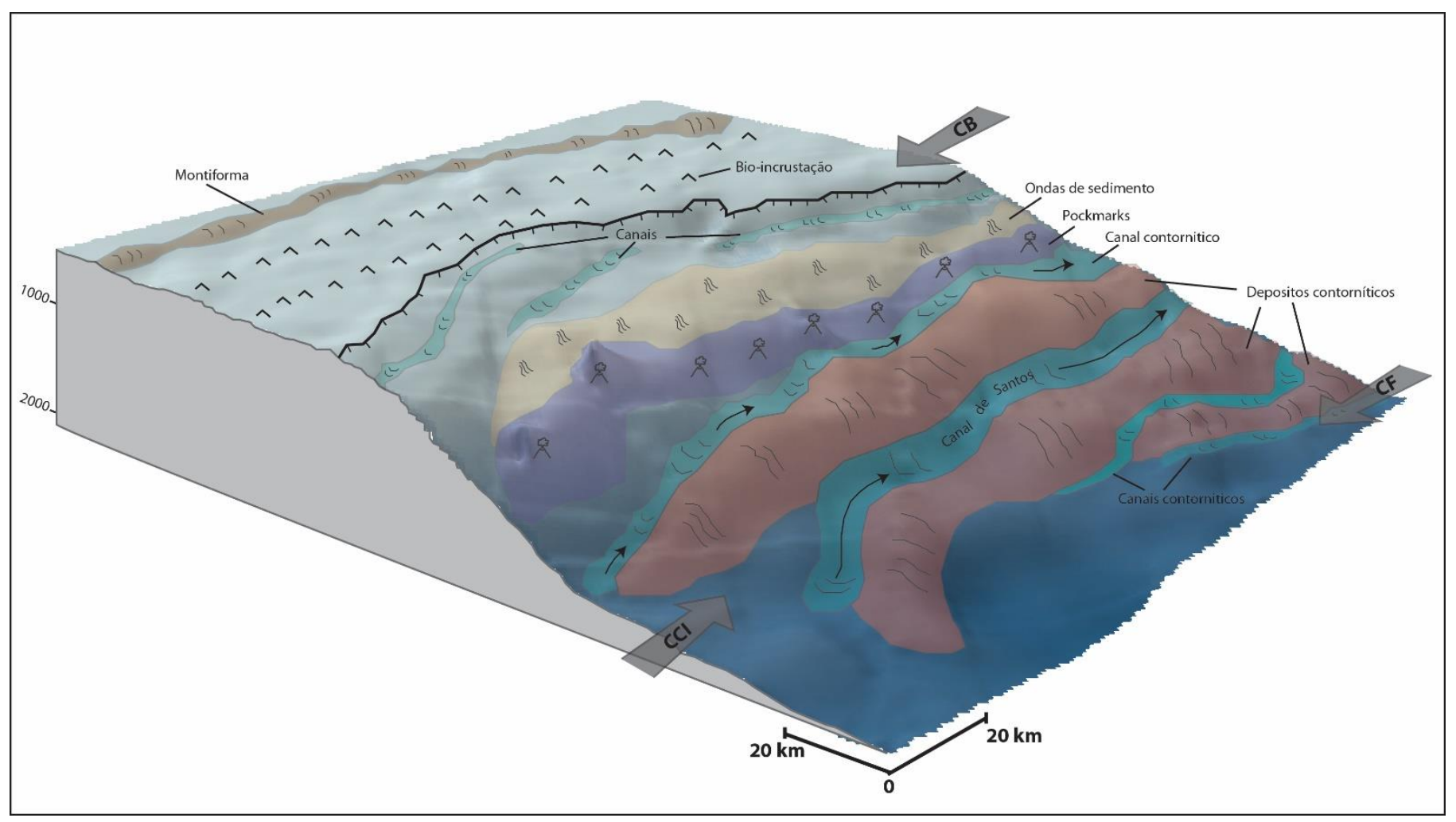

Figura 66. Bloco esquemático do modelo morfológico e sedimentar da área de estudo. 


\section{CONCLUSÕES}

Da análise integrada de registros batimétricos e sísmicos rasos foi possível reconhecer importante variabilidade espacial na morfologia e processos sedimentares da área de estudo. Destacam-se, também, evidências de variações temporais nos processos oceanográficos, refletidas em modificações nos padrões de eco dos registros sísmicos. As conclusões mais importantes podem ser sintetizadas:

- A Plataforma Continental Externa apresenta uma morfologia extremamente irregular, com presença de escarpas, paleocanais e depressões erosivas e montiformas. Essas irregularidades morfológicas indicam a atuação de processos erosivos relacionados aos períodos de exposição subaérea durante períodos regressivos e posteriormente afogamento em períodos transgressivos.

- A Plataforma externa pode ser classificada por ser faminta, não evidenciando aporte significativo de sedimento. A plataforma é predominantemente carbonática e há presenças de inúmeras feições bioconstrutivas, principalmente próximo à quebra.

- A Corrente do Brasil é o principal agente erosivo que atua sobre a plataforma externa e Talude Superior. Devido ao seu comportamento meandrante junto à borda Plataforma-Talude, a Corrente do Brasil além de erodir a superfície, evita que ocorra atual sedimentação pelágica neste setor. 
- A Corrente do Brasil erodindo a interface plataforma-talude acaba esculpindo canais e escarpas paralelamente ao talude. Esses canais podem sofrer migrações laterais, indicando a ocorrência da migração do núcleo da Corrente do Brasil ao longo de períodos transgressivos e regressivos.

- No Talude Superior, entre 350 - 550 metros foram encontradas evidências de ondas de sedimentos, provavelmente em períodos regressivos. Posteriormente verifica-se a mudança na dinâmica local ao longo do tempo, com o recobrimento dos depósitos por sedimentos que apresenta padrão de deposição hemipelágica.

- A região acha-se sob a influência de falhas oriundas provavelmente da atividade de diápiros de sal. Esse fato pode ser constatado com o alinhamento de inúmeros pockmarks na faixa de 600 a 850 metros. Vários destes pockmarks estão ativos com a presença de exsudação de gás, outros inativos e outros abandonados com recobrimento de sedimento mais recente.

- Abaixo da isóbata dos 1000 metros a região se acha sob o domínio de contornitos. Naquele trecho foram identificados depósitos e canais ao longo da área de estudo. Esse padrão está relacionado às intensificações dos fluxos gerados pela $\mathrm{CCl}$ e nas porções mais profundas $(>1800 \mathrm{~m})$ pela CCP.

- O Canal de Santos está disposto paralelamente ao longo de talude, próximo à isóbata de 1600 metros e com uma profundidade média de 100 metros. O canal é classificado como contornítico e gera depósitos 
no seu flanco direito. Observou-se que o fluxo no Canal de Santos sofreu alterações ao longo do tempo, pois há mudanças no padrão de deposição na sua calha central.

- Inúmeros canais perpendiculares ao Talude inferior foram constatados, que possivelmente são canais tributários formados a partir do fluxo do Canal de Santos.

- Após o Canal de Santos a presença de inúmeros canais contorníticos dispostos paralelamente ao talude. Seus depósitos são alongados e se estendem para o interior da bacia.

Assim, com respostas às hipóteses geradas no início do trabalho, verifica-se:

- As correntes de contorno exercem papel fundamental no processo de modelagem da morfologia do fundo, erodindo e também transportando sedimentos para outras áreas.

- A Corrente do Brasil é o principal agente erosivo da Plataforma Continental Externa, evitando que os sedimentos atuais se depositem e erodindo sequencias anteriores.

- Embora tenham sido encontrados canais com dimensões de cânions no Talude Inferior, não se atribuiu esta classificação a eles, por não ser visível em várias seções sondadas, ou seja, sua expressão era detectada somente no local e não na área como um todo. 


\section{REFERÊNCIAS BIBLIOGRÁFICAS}

ALMEIDA, A.G.; KOWSMANN, R.O. 2011. Caracterização geomorfológica do fundo marinho do talude Continental da bacia de campos, RJ. XIII Congresso da Associação Brasileira de Estudos do Quaternário.

ALMEIDA, F.F.M.; CARNEIRO, C.D.R.; MIZUSAKI, A.M.P. 1996. Correlação do magmatismo das Bacias da Margem Continental Brasileira com o das areas emersas adjacentes. Revista Brasileira de Geociências, v. 23, n. 3, p. $125-138$.

ALMEIDA, F.F.M.; CARNEIRO, C.R. 1998. Origem e evolução da Serra do Mar. Revista Brasileira de Geociências, v. 28, n.2, p. 135 - 150.

ALONSO, B.; ERCILLA, G. 2003. Small turbidite systems in a complex tectonic setting (SW Mediterranean Sea): morphology and growth patterns. Marine and Petroleum Geology, v.19, p. 1225 - 1240.

ALVES, E. C., PONZI V. R. 1984. Características morfológico-sedimentares da plataforma continental e talude superior da margem continental sudeste do Brasil. XXXVIII Cong. Bras. Geologia. pp. 1629-1642.

ALVES, M.A., 1992. Correntes de maré e inerciais na plataforma continental ao largo de Ubatuba (SP). (Dissertação mestrado) Instituto Oceanográfico da Universidade de São Paulo (USP), São Paulo, Brazil (162pp.).

ANGULO, R.J., LESSA,G.C, SOUZA, M.C., 2006. A critical review of Mid-to Late Holocene sea-level flutuctuations on the eastern Brazilian coastline. Quat. Sci. Ver. 25, 486-506.

BILÓ, T.C.; SILVEIRA, I.C.A.; BELO, W.C.; CASTRO, B.M.; PIOLA, A. R. 2014. Methods for estimating the velocities of the Brazil Current in the pre-salt reservoir area off southeast Brazil (23 $\circ S-26 \circ S)$. Ocean Dynamics, v. 64 , n. 10 , p. $1431-1446$. 
BOebel, O., R. E. DAVIS, M. Ollitraut, R. G. Peterson, P. L. RICHARD, C. SCHMID,; W. ZENK, 1999: The intermediate depth circulation of the Western South Atlantic. Geophys. Res. Lett., 26(21), 3329-3332.

CAINELLI, C. \& MOHRIAK, W. U. 1999. Some remarks on the evolution of sedimentary basins along the Eastern Brazilian continental margin. Episodes, 22, 206-216.

CALDAS, M.F.; ZALÁN, P.V. 2009. Reconstituição cinemática e tectonosedimentação associada a domos salinos nas águas profundas da Bacia de Santos, Brasil. Boletim de Geociências da Petrobrás, v.17, n. 2, p. $227-248$.

CAMPOS, E,J.D.; GONÇALVES, J.E; IKEDA, Y. 1995. Water Mass Structure and Geostrophic Circulation in the South Brazil Bight -- Summer of 1991. Journal of Geophysical Research, v. 100, n. C9 , p. 18537 - 18550.

CAMPOS, E.J.D.; IKEDA, Y.; CASTRO FILHO, B.M.; GAETA, S.A.; LORENZETTI, J.A.; STEVENSON, M.R. 1996. Experiment studies circulation in western South Atlantic, EOS, v. 77, p. 253-259.

CARLSON, P.R.; KARL, H.A. 1988. Development of large submarine canyons in the Bering Sea, indicated by morphologic, seismic, and sedimentologic characteristics. Geological Society of America Bulletin, v. 100, p.1594 1615.

CASTRO FILHO, B.M., 1996. Correntes e massa de água da plataforma continental norte de São Paulo. Tese livre docência, Insituto Oceanográfico, Universidade de São Paulo, São Paulo. 246p.

CASTRO FILHO, B.M.; MIRANDA, L.B.; MIYAO, S.Y. 1987. Condições oceanográficas na plataforma continental ao largo de Ubatuba: variações sazonais em média escala. Boletim do Instituto Oceanográfico, v. 35, p. $135-151$. 
CONCEIÇÃO, J.C.; ZALÁN, P.V.; WOLFF, S. 1988. Mecanismo, Evolução e cronologia do rift sul-atlântico (Mechanism, evolution and chronology of South Atlantic Rifting). Boletim de Geociências Petrobrás, v. 2, n. 2/4, p. $255-265$.

CORRÊA, I.C.S.; PONZI, V.R.A.; TRINDADE, L.A.F., 1980. Níveis marinhos quaternários da plataforma continental do Rio de Janeiro. XXXI Cong. Bras. Geologia, pp. 578-587.

DEMERCIAN, S.; SZATMARI, P.; COBBOLD, P.R., 1993. Style and pattern of salt diapirs due to thin-skinned gravitational gliding, Campos and Santos basins, offshore Brazil. Tectonophysics 228, 393-433.

DIAS, G. T. M., GORINI, M. A., GALLEA, C. G., ESPINDOLA, C. R. S., DELLAPIAZZA, H., CASTRO, J. R. J. C. 1982. Bancos de Arenitos de Praia (Beach Rocks) Submersos na Plataforma Continental SE Brasileira. XXXII Cong. Bras. Geologia. pp. 1540-1546.

DIAS, J.L., SAD, A.R.E., FONTANA, R.L., FEIJÓ, F.J., 1994. Bacia de Pelotas. Boletim de Geociências da Petrobras 8, 235-245.

DUARTE, C. S. L.; VIANA, A. R. 2007. Santos Drift System: stratigraphic organization and implications for late Cenozoic palaeocirculation in the Santos Basin, SW Atlantic Ocean. The Geological Society, 276:171-198.

DUCK, R.W.; WEWETZER, S.F.K. 2000. Relationship between current measurements and sonographs of subtidal bedforms in the macrotidal Tay Estuary, Scotland. In: PYE K e ALLEN JRL (Ed.). Coastal and Estuarine Environments: sedimentology, geomorphology and geoarchaeology. Geological Society,London, Special Publications, 175: $31-41$.

EVANS, D.; S. R. SIGNORINI, 1985: Vertical structure of the Brazil Current. Nature, 315, 48-50. 
FAUGÈRES, J. C.; STOW D.A.V. 1993. Bottom-current-controlled sedimentation: a synthesis of the contourite problem Sediment. Geol., 82, pp. 287-297.

FIGUEIREDO JR, A. G.; TESSLER, M. G. 2004. Topografia e composição do substrato marinho da Região Sudeste-Sul do Brasil. São Paulo, Instituto Oceanográfico, USP. Série Documentos Revizee - Score Sul. 64 p.

FÚLFARO, V.J.; SUGUIO, K.; PONÇANO, W.L. 1974. A gênese das planícies costeiras paulistas. In: Congresso Brasileiro de Geologia, 28. Anais. Porto Alegre, Sociedade Brasileira de Geologia. v.3. p. 37 - 42.

GAMBOA, L.A.P.; PHILIP D. RABINOWITZ, P.D. 1981. The Rio Grande fracture zone in the western South Atlantic and its tectonic implications, Earth and Planetary Science Letters, Volume 52, Issue 2, Pages 410418.

GARFIELD III, N. 1990. The Brazil Current at Subtropical Latitudes. Ph.D. Thesis, University of Rhode Island. $121 \mathrm{p}$.

GE, H., JACKSON, M. P. A. \& VENDEVILLE, B. C. 1997. Kinematics and dynamics of salt tectonics driven by progradation. American Association of Petroleum Geologists Bulletin, 81, 393-423.

GODOI, S. S., 2005: Dinâmica quase-geostrófica do sistema Corrente do Brasil no embanhamento de São ao Paulo (23,5॰-27॰S). Tese de Doutorado, Universidade de São Paulo, São Paulo, 133 pp.

KARNER, G.D., DRISCOLL, N.W., 1999. Tectonic and stratigraphic development of the West African and eastern Brazilian margins: insights from quantitative basin modeling. In: Cameron, N.R., Bate, R.H., Clure, V.S. (Eds.), The Oil and Gas Habitats of the South Atlantic. Geological Society of London, Special Publications, vol. 153, pp. 11-40.

KOWSMANN, R.O. E COSTA, M.O.A., 1979. Sedimentação quaternária da margem continental brasileira e das áreas oceânicas adjacentes. In: REMAC PROJECT (Final Report). Petrobras Rio de Janeiro. pp. 1-55. 
KOWSMANN, R.O.; MACHADO, L.C.R.; VIANA, A.R.; ALMEIDA JR., W. 2002. Controls on Mass-Wasting in Deep Water of the Campos Basin. Offshore Technology Conference, Houston, p. 1 - 11.

LASTRAS, G.; ARZOLA, R.G.; MASSON, D.G.; WYNN, R.B.; HUVENNE, V.A.I.; HÜHNERBACH, V.; CANALS, M. 2009. Geomorphology and sedimentary features in the Central Portuguese submarine canyons, Western Iberian margin. Geomorphology, v. 103, p. $310-329$.

LEE, H.J., SYVITSKI, J.P.M., PARKER, G., ORANGE, D., LOCAT, J., HUTTON, E.W.H., IMRAN, J., 2002. Distinguishing sediment waves from slope failure deposits: field examples, including the 'Humboldt Slide' and modelling results. Marine Geology, 192: 79-104.

LEGEAIS, J.F.; OLLITRAULT, M.; ARHAN, M. 2013. Lagrangian observations in the Intermediate Western Boundary Current of the South Atlantic. Deep-Sea Res II, v. 85, p. $109-126$.

LIBES, S.M. 1992. An introduction to marine biogeochemistry . John Wiley \& Sons, Inc.New York. 734p.

LIMA, A.F. 2003. Comparação dos Sistemas Sedimentares Profundos da Bacia Sudeste-Sul do Brasi com ênfase no Sistema Misto Colúmbia. Tese (Doutorado), Instituto Oceanográfico. Universidade de São Paulo, São Paulo. 252p.

LIMA, M.R.B.L.A. 2000. Natureza e origem da matéria orgânica depositada nos sedimentos superficiais ao longo da plataforma continental entre as cidades do Rio de Janeiro (RJ) e São Francisco do Sul (SC). Dissertação (Mestrado), Instituto Oceanográfico. Universidade de São Paulo, São Paulo. 115p.

LOBO, F. J., DIAS, J. M. A., HERNÁNDEZ-MOLINA, F. J., GONZÁLEZ, R., FERNÁNDEZ-SALAS, L. M., DÍAZ DEL RIO, V. 2005. Late Quaternary shelf-margin wedges and upper slope progradation in the Gulf of Cadiz margin (SW Iberian Peninsula). Geological Society, 244:7-25. 
LOBO, F.J.; GONZÁLEZ, R.; DIAS, J.M.A.; MENDES, I.; DEL RIO DÍAZ, V. 2002. Influence of estuarine morphology on bedload sediment transport patterns: an example from the Guadiana estuary (SE Portugal). Publicações da Associação Portuguesa de Geomorfólogos, v. 1, p. 87 98.

MACEDO, J. M. 1990. Evolução tectônica da Bacia de Santos e áreas continentais adjacentes. In: GABAGLIA, G. P. R. \& MILANI, E. J. (eds) Origem e evolução de bacias sedimentares. Petrobrás, Rio de Janeiro,361-376.

MAHIQUES M.M.; SOUZA L.A.P. 1995. Shallow seismic reflectors and upper Quaternary sea level changes in the Ubatuba region, São Paulo State, Southeastern Brazil. Revista Brasileira de Oceanografia, v. 47, p. 1 - 10.

MAHIQUES, M.M.; ANGULO, R.J.; VEIGA, F.A.; KLEIN, D.A.; SOUZA, M.C. 2007. Evidences of high sea level during isotope stage 3 ? Two case studies from the southern Brazilian inner shelf and coast. XVII INQUA Congress Abstracts, Cairns, Australia. Quaternary International, v. 167168 , p. $263-263$.

MAHIQUES, M.M.; BÍCEGO, M.C.; SILVEIRA, I.C.A.; SOUZA, S.H.M.; LOURENÇO, R.A.; FUKUMOTO, M.M. 2005. Modern sedimentation in Cabo Frio upwelling system, Southeastern Brazilian shelf. Anais da Academia Brasileira de Ciências, v. 77, n. 3, p. 535 - 548.

MAHIQUES, M.M.; MISHIMA, Y.; RODRIGUES, M. 1999. Characteristics of the sedimentary organic matter on the inner and middle continental shelf between Guanabara Bay and São Francisco do Sul, Southeastern Brazilian margin. Continental Shelf Research, v. 19, p. 775 - 798.

MAHIQUES, M.M.; SILVEIRA, I.C.A.; SOUSA, S.H.M.; RODRIGUES, M. 2002. Post-LGM sedimentation on the outer shelf - upper slope of the northernmost part of the São Paulo Bight, southeastern Brazil. Marine Geology, v. 181 , p. $387-400$. 
MAHIQUES, M.M.; TASSINARI, C.C.G.; MARCOLINI, S.; VIOLANTE, R.A.; FIGUEIRA, R.C.L.; SILVEIRA, I.C.A.; BURONE, L.; SOUSA, S.H.M. $2008 \mathrm{Nd}$ and $\mathrm{Pb}$ isotope signatures on the Southeastern South American upper margin: Implications for sediment transport and source rocks. Marine Geology, v. 250, p. $51-63$.

MAHIQUES, M.M.; TESSLER, M.G.; CIOTTI, A.M.; SILVEIRA, I.C.A.; SOUSA, S.H.M.; FIGUEIRA, R.C.L.; TASSINARI, C.C.G.; FURTADO, V.V.; PASSOS, R.F. 2004. Hydrodynamically driven patterns of recent sedimentation in the shelf and upper slope off Southeast Brazil. Continental Shelf Research, v. 24, p. 1685 - 1697.

Mahiques, M. M.; Shattner, U.; Lazar, M. 2015. Spatial analysis in a giant pockmark field, SE Brazilian slope. In: Geohab 2015. Book of Abstracts. http://www.geohab2015.org/wpcontent/uploads/2015/04/Resumos_geohab2015.pdf

MEISLING, K. E., COBBOLD, P. R.; MOUNT, V. S. 2001. Segmentation of an obliquely rifted margin, Campos and Santos basins, southeastern Brazil. American Association of Petroleum Geologists, Bulletin, 11, 1903-1924.

MÉMERY, L.; ARHAN, M.; ALVAREZ-SALGADO, X. A.; MESSIAS, M.J.; MERCIER, H.; CASTRO, C.G; RIOS, A. F. 2000 The water masses along the western boundary of the south and equatorial Atlantic. Prog Oceanog 47(1):69-98.

MILANI, E. J. \& THOMAZ FILHO, A. 2000. Sedimentary basins of South America. In: CORDANI, U. G., MILAN, E. J., THOMAZ FILHO, A. \& CAMPOS, D. A. (eds) Tectonic evolution of South America, 31st International Geological Congress, Rio de Janeiro, 389-449.

MILLIMAN, J.D., 1978. Morphology and structure of the upper continental margin of Southern Brazil. Bulletin of the American Association of Petroleum Geologists 62, 1029-1048.

MODICA, C. J. \& BRUSH, E. R. 2004. Postrift sequence stratigraphy, paleogeography, and fill history of the deep-water Santos Basin, offshore 
southeast Brazil. American Association of Petroleum Geologists Bulletin, 88, 923-946.

MOHORIAK, W. 2003. Bacias Sedimentares da Margem Continental Brasileira. Capítulo 3, In: BIZZI, L.A.; SCHOBBENHAUS, C.; VIDOTTI, R.M.; GONÇALVES, J.H. In: (Eds.) Geologia, Tectônica e Recursos Minerais do Brasil, CPRM, Brasília. p. 87-165.

MOHRIAK, W. U., MACEDO, J.M. 1995. Salt tectonics and structural styles in the deep-water province of the Cabo Frio region, Rio de Janeiro, Brazil. In: JACKSON, M. P. A., ROBERTS, D. G. \& SNELSON, S. (eds) Salt tectonics: a global perspective. American Association of Petroleum Geologists, Memoirs, 65, 273-304.

MÖLLER JR, O.O.; PIOLA, A.R.; FREITAS, A.C.; CAMPOS, E.J.D. 2008. The effects of river discharge and seasonal winds on the shelf off southeastern South America. Continental Shelf Research, v. 28, p. 1607 -1624 .

MOREIRA, J.L.P., MADEIRA, C.V., GIL, J.A., MACHADO, A.P.M., 2007. Bacia de Santos. Boletim de Geociências da Petrobras, Rio de Janeiro 15 (2), 531-549.

MOREIRA, J.L.P.; MADEIRA, C.V.; GIL, J.A.; MACHADO, M.A.P. 2007. Bacia de Santos. Boletim de Geociências da Petrobrás, v. 15, n. 2, p. 531 550 .

MOUNTJOY, J.J.; BARNES, P.M.; PETTINGA, J.R. 2009. Morphostructure and evolution of submarine canyons across an active margin: Cook Strait sector of the Hikurangi Margin, New Zealand. Marine Geology, v. 260, p. $45-68$.

NADIM F.; KJEKSTAD, O.; PEDUZZI, P.; HEROLD, C.; JAEDICKE, C. 2006 Global landslide and avalanche hotspots. Landslides, v. 3, p. $159-173$.

OBELCZ, J.; BROTHERS, D.; CHAYTOR, J.; BRINK, U.; ROSS, S.W.; BROOKE, S. 2013. Geomorphic characterization of four shelf-sourced 
submarine canyons along the U.S. Mid-Atlantic continental margin. Deep Sea Research Part II: Topical Studies in Oceanography, v. 104, p. 106 119.

PEREIRA, M. J. \& FEIJÓ, F. J. 1994. Bacia de Santos. Boletim de Geociências da Petrobrás, 8, 219-234.

PEREIRA, M. J. \& MACEDO, J. M. 1990. A Bacia de Santos: perspectivas de uma nova província petrolífera na plataforma continental sudeste brasileira. Boletim de Geociências da Petrobras, 4, 3-11.

REBESCO, M., 2005. Contourites. In: Selley, R.C., Cocks, L.R.M., Plimer, I.R. (Eds.), Encyclopedia of Geology. Elsevier, Oxford, pp. 513-527.

REBESCO, M., 2014. Contourites. In: Elias, S.A. (Ed.), Reference Module in Earth Systems and Environmental Sciences. Elsevier.

REBESCO, M.; HERNÁNDEZ-MOLINA, F.J.; ROOIJ, D.V.; WÅHLIN, A. 2014 Contourites and associated sediments controlled by deep-water circulation processes: state-of-the-art and future considerations. Marine Geology 352:111-154.

REIS, A.T.; MAIA, R.M.C.; SILVA, C.G.; RABINEAU, M.; GUERRA, J.V.; GORINI, C.; AYRES, A.; ARANTES-OLIVEIRA, R.; BENABDELLOUAHED, M.; SIMÕES, I.; TARDIN, R. 2013. Origin of step-like and lobate seafloor features along the continental shelf off Rio de Janeiro State, Santos basin-Brazil. Geomorphology, v. 203, n.1, p. $25-45$.

SHEPARD, F.P. 1972. Submarine canyons. Earth-Science Reviews, v. 8, p. 1 12.

SHEPARD, F.P.; DILL, R.F. 1966. Submarine canyons and Others Sea Valleys. Rand McNally, Chicago, Illinois. 381 p. 
SIGNORINI, S.R. 1978. On the circulation and the volume transport of the Brazil Current between the Cape of São Tomé and Guanabara Bay. Deep-Sea Research, v. 25, p. $481-490$.

SILVEIRA, I. C. A.; L. CALADO; B. M. CASTRO; M. CIRANO; J. A. M. LIMA; A. S. MASCARENHAS, 2004: On the baroclinic structure of the Brazil Current Intermediate Western Boundary Current System. Geophys. Res. Lett.,31(14), L14.308.

SILVEIRA, I.C.A.; SCHMIDT, A.C.K.; CAMPOS, E.J.D.; GODOI, S.S.; IKEDA, Y. 2000. A Corrente do Brasil ao Largo da Costa Leste Brasileira. Revista Brasileira de Oceanografia, v.48, n. 2, p. 171 - 183.

SOUTHARD, J.B., E STANLEY, D.J. 1976. Shelf-break processes and sedimentation. In Marine sediment transport and environmental management. pp. 351-377.

SOUZA, L. A. P.; TESSLER, M. G.; GALLI, V. L. 1996. O graben de Cananéia. Revista Brasileira de Geociências, São Paulo, v. 26, p. 139-150.

SOUZA, L.A.P. 2006. Revisão crítica da aplicabilidade dos métodos geofísicos na investigação de áreas submersas rasas. Tese de Doutorado, Instituto Oceanográfico, Universidade de São Paulo, São Paulo. 311 p.

STANLEY, D.J., MOORE, G.T., 1983. The shelfbreak: critical interface on continental margins. Society of Economic Paleontologist and Mineralogist Special Publication, 33 (467 pp.).

STOMMEL, H., 1958: The abyssal circulation. Deep-Sea Res.,5, 80-82.

STOW, D.A.V., KAHLER, G., REEDER, M., 2002. Fossil contourites: type example from an Oligocene palaeoslope system, Cyprus. In: Stow, D.A.V., Pudsey, C.J., Howe, J.A., Faugères, J.-C., Viana, A.R. (Eds.), Deep-water Contourite Systems: Modern Drifts and Ancient Series, Seismic and Sedimentary Characteristics. Geological Society, London, Memoir, 22, pp. 443-455. 
STRAMMA, L.; ENGLAND, M. 1999. On the wather masses and mean circulation of the South Atlantic Ocean. J Geophys Res 104(C9):20, 86320, 883 .

StRAMMA, L.; R. G. PETERSON, 1990: The South Atlantic Current. J. Phys. Oceanogr., 20, 846-859.

SUGUIO, K.; MARTIN, L. 1978. Formações quaternárias marinhas do litoral paulista e sul-fluminense. In: International Symposium on Coastal Evolution in the Quaternary. Special Publication. São Paulo, Instituto de Geociências da USP - Sociedade Brasileira de Geologia. v. 1, p. 1 - 5.

SZATMARI, P., GUERRA, M. C. M. \& PEQUENO, M. A. 1996. Genesis of large counter-regional normal fault by flow of Cretaceous salt in the South Atlantic, Santos Basin, Brazil. In: ALSOP, G. I., BLUNDELL, D. J. \& DAVISON, I. (eds) Salt Tectonics. Geological Society, London, Special Publications, 100, 259-264.

VICALVI, M.A.; KOWSMANN, R.O.; COSTA, M.P.A. 1979. Depressão de Abrolhos: uma paleolaguna holocênica na plataforma continental brasileira. Boletim Técnico da Petrobrás, v. 21, p. $279-286$.

WEWETZER, S.F.K.; DUCK, R.W.; MCMANUS, J. 1999. Sidescan sonar mapping of bedforms in the middle Tay Estuary, Scotland. International Journal of Remote Sensing, v. 20, p. $511-522$.

WEWETZER, S.F.K; DUCK, R.W. 1999. Bedforms of the middle reaches of the Tay Estuary, Scotland. Special Publications of the International Association of Sedimentologists, v. 28, p. $33-41$.

WYNN, R.B., STOW, D.A.V., 2002. Classification and characterisation of deepwater sediment waves. Marine Geology 192 (1-3), 7-22.

ZALÁN, P.V., OLIVEIRA, J.A.B., 2005. Origem e evolução estrutural do Sistema de Riftes Cenozóicos do Sudeste do Brasil. Boletim de Geociências da Petrobras 13, 269-300. 
ZEMBRUSKI, S.G. 1979. Geomorfologia da margem continental sul-brasileira e das bacias oceânicas adjacentes. In: Chaves, H.A.F. (Ed.) Geomorfologia da margem continental brasileira e das bacias oceânicas adjacentes, Rio de Janeiro, Petrobrás. v. 7, p. $129-177$. 